\title{
Geochemical Profiles Across the Listvenite-Metamorphic Transition in the Basal Megathrust of the Semail Ophiolite: Results from Drilling at Oman DP Hole BT1B
}

M. Godard ${ }^{1 *}$, E.J. Carter ${ }^{2}$, T. Decrausaz ${ }^{1}$, R. Lafay ${ }^{1}$, E. Bennett ${ }^{3}$, F. Kourim ${ }^{4}$, J.-C. de Obeso $^{5}$, K. Michibayashi ${ }^{6}$, M. Harris ${ }^{7}$, J. Coggon ${ }^{8}$, D. Teagle ${ }^{8}$, P. Kelemen ${ }^{5}$ and the Oman Drilling Project Phase 1 Science Party†

${ }^{1}$ Géosciences Montpellier, CNRS, Université de Montpellier, Montpellier, France

${ }^{2}$ Department of Earth and Environmental Sciences, The University of Manchester, Manchester, United Kingdom

Now at: Department of Geology, Trinity College Dublin, Dublin 2, Ireland

${ }^{3}$ School of Earth and Ocean Sciences, Cardiff University, Cardiff, United Kingdom

${ }^{4}$ Academia Sinica, Institute of Earth Science, Taipei, Taiwan

${ }^{5}$ LDEO, Columbia University, Palisades, NY, United States

${ }^{6}$ Dep. Earth and Planetary Sciences, Graduate School of Environmental Studies, Nagoya University, Nagoya, Japan

${ }^{7}$ School of Geography, Earth and Environmental Sciences, Plymouth University, Plymouth, United Kingdom

${ }^{8}$ School of Ocean \& Earth Science, University of Southampton, United Kingdom

* Corresponding author: Marguerite Godard (Marguerite.Godard@umontpellier.fr)

Key Points:

- BT1B listvenite series and metamorphic sole derive from partially serpentinized basal banded peridotites and alkaline basalts respectively

- Chemical redistribution suggests reactions with several batches of $\mathrm{CO}_{2}$-rich fluids over various flow paths parallel to the basal thrust

- Listvenitization due to $\mathrm{CO}_{2}$ metasomatism could represent a major trap-and-release mechanism for $\mathrm{CO}_{2}$, FME and $\mathrm{H}_{2} \mathrm{O}$ along convergent margins

\section{Citation:}

Godard, M., Carter, E. J., Decrausaz, T., Lafay, R., Bennett, E., Kourim, F., J.-C. de Obeso, K. Michibayashi, M. Harris, J. Coggon, D. Teagle, P. Kelemen and the Oman Drilling Project Phase 1 Science Party (2021). Geochemical profiles across the listvenite-metamorphic transition in the basal megathrust of the Semail ophiolite: Results from drilling at OmanDP Hole BT1B. Journal of Geophysical Research: Solid Earth, 126, e2021JB022733. https:// doi.org/10.1029/2021JB022733

Received 8 JUL 2021 Accepted 25 NOV 2021 


\begin{abstract}
The transition from the Semail ophiolite mantle to the underlying metamorphic sole was drilled at ICDP OmanDP Hole BT1B. We analyzed the bulk major, volatile and trace element compositions of the mantle-derived listvenite series and metamorphic rocks, with the aim to constrain chemical transfers associated with peridotite carbonation along the ophiolite basal thrust. The listvenite series comprise variously carbonated serpentinites and (fuchsite-bearing) listvenites. They have high $\mathrm{CO}_{2}$ (up to 43 wt.\%) and variable $\mathrm{H}_{2} \mathrm{O}(0-12$ wt.\%). Yet, they have compositions close to that of the basal banded peridotites for most major and lithophile trace elements, with fuchsite-bearing listvenites overlapping in composition with amphibole-bearing basal lherzolites (e.g., $\mathrm{Al}_{2} \mathrm{O}_{3}=0.1-2.2$ wt.\%; $\mathrm{Yb}=0.05-1$ x CI-chondrite). The protolith of the listvenite series was likely similar in structure and composition to serpentinized banded peridotites which immediately overlie the metamorphic sole elsewhere in Oman. The listvenite series are enriched in fluid mobile elements (FME) compared to Semail peridotites (up to $\sim 10^{3}$ $10^{4} \mathrm{x}$ Primitive Mantle), with concentrations similar to the underthrusted metabasalts and/or metasediments for $\mathrm{Cs}, \mathrm{Sr}$ and $\mathrm{Ca}$ and sometimes even higher for $\mathrm{Pb}, \mathrm{Li}, \mathrm{As}$, and $\mathrm{Sb}$ (e.g., $\mathrm{Li}$ up to $130 \mu \mathrm{g} / \mathrm{g}$; As up to $170 \mu \mathrm{g} / \mathrm{g})$. We also observe a decoupling between Sr-Ca enrichments and other FME, indicating interactions with several batches of deep $\mathrm{CO}_{2}$-rich fluids transported along the basal thrust. These results suggest that peridotite carbonation could represent one of the major trap-and-release mechanisms for carbon, water and FME along convergent margins.
\end{abstract}

\title{
Plain Language Summary
}

Ophiolites are sections of oceanic lithosphere emplaced on-land as tectonic plates converge. The faults developed at their base are analogues to plate interfaces in subduction zones, where mass transfers occur and play a key role in the global cycling of elements. A core was drilled at the base of the Semail Ophiolite, where variously hydrated and carbonated mantle rocks known as serpentinites and listvenites witnessed major fluid fluxes. Reactions with $\mathrm{CO}_{2}$-bearing fluids (carbonation reaction) enhanced the mobility of elements during mass transfers along the basal thrust. We measured the elemental composition of 84 samples spaced along this core. Results indicate that $\mathrm{CO}_{2}$-bearing fluids derive from at least two sources or pathways. As peridotites reacted, their volume increased, causing cracking, helping the ingress of reactive fluids and allowing (almost) complete carbonation of the basal ophiolite mantle. Carbon as well as many elements such as cesium, arsenic, antimony, lead, became enriched in these rocks. If forming in subduction zones, listvenites may act as temporary storage for these elements and impact global chemical cycles.

Keyword : Peridotites, Serpentinization, Carbonation, Si-metasomatism, Fluid-rock interactions, Mass balance, Geochemical cycles, Fluid pathways, ICDP Oman Drilling Project 


\section{Introduction}

Listvenites (or listwaenites) are produced by $\mathrm{CO}_{2}$-metasomatism of mantle-derived ultramafic rocks [Falk and Kelemen, 2015; Halls and Zhao, 1995]. They are composed mainly of quartz and carbonate (magnesite and/or dolomite, \pm Cr- or Mg-rich micas \pm chlorite) and are often associated with serpentinites, ophicarbonates and/or talc. Since their first description in the literature [Rose, 1837], they have been investigated for one of their main characteristics: the occurrence of mineralizations concentrating economically-valuable metals, such as Au, Pb-HgAg, Cu, Ni, Co or Sb (e.g., [Belogub et al., 2017; Buisson and Leblanc, 1985; Escayola et al., 2009; Halls and Zhao, 1995; Laznicka, 2010]). More recently, they have been studied also as natural analogues for industrial geological carbon storage in ultramafic basement [Falk and Kelemen, 2015; Hansen et al., 2005; Ulrich et al., 2014].

These studies have highlighted the structural, mineralogical and petrological complexity of listvenites, thus resulting in a wealth of different and sometimes contradictory genetic models [Belogub et al., 2017; Falk and Kelemen, 2015; Halls and Zhao, 1995; Nasir et al., 2007]. Some authors evoke serpentinization of mantle peridotites followed by the formation, concurrent or consecutive, of carbonate (carbonation) and quartz (silicification) [Boschi et al., 2009; Nasir et al., 2007; Stanger, 1985; Ulrich et al., 2014], whilst others suggest direct reactions with primary mantle minerals [Hansen et al., 2005; Kelemen et al., 2011; Power et al., 2013]. Other authors stress the role of the composition of the infiltrating $\mathrm{CO}_{2}$-bearing fluid rather than that of the protolith in the genesis of listvenites and associated ore-grade mineralizations [Belogub et al., 2017; Escayola et al., 2009; Halls and Zhao, 1995; Menzel et al., 2020a; Menzel et al., 2018; Stanger, 1985], often emphasizing a possible imprint of silica and other cations scavenged from neighboring lithologies [Nasir et al., 2007; Ulrich et al., 2014]. The estimated temperatures of formation and the proposed source(s) of fluids also differ: fluid-inclusions and thermodynamic analyses of carbonate-quartz assemblages suggest reaction within a temperature range from 120 to $280^{\circ} \mathrm{C}$ (down to $80^{\circ} \mathrm{C}$ and up to $400^{\circ} \mathrm{C}$ ) and likely triggered by the infiltration of slab-derived fluids [Belogub et al., 2017; Boskabadi et al., 2020; Escayola et al., 2009; Hansen et al., 2005; Menzel et al., 2018]. On the other hand, petrographic and geochemical analyses show also that some listvenite series were formed during weathering $\left(<50^{\circ} \mathrm{C}\right)$ by silicification reactions triggered by interactions with fluids in equilibrium with atmospheric $\mathrm{CO}_{2}$ (e.g., [Stanger, 1985; Ulrich et al., 2014]) whilst others show evidence for distinct fluid infiltration and weathering episodes (e.g., [Nasir et al., 2007]). Finally, the mechanisms allowing the infiltration of the $\mathrm{CO}_{2-}$ rich metasomatic fluids remain speculative with suggested mechanisms including the role of large faults and deformation, reactive cracking and dissolution [Escayola et al., 2009; Falk and Kelemen, 2015; Nasir et al., 2007].

The first difficulty to unravel the genesis of listvenites stems from their environments: they crop out along ophiolitic and orogenic belts as part of highly altered rock assemblages, which often have undergone several stages of metamorphic and tectonic overprint (e.g., [Azer et al., 2019; Halls and Zhao, 1995; Menzel et al., 2018; Nasir et al., 2007]). For these reasons, both the protolith and potential $\mathrm{CO}_{2}$ source(s) for listvenite-forming metasomatism are difficult to identify, and display significant structural, mineralogical and compositional variability. Only a few sites allow sampling the transition from mantle peridotites to the possible source(s) of $\mathrm{CO}_{2}$ metasomatism: the Semail ophiolite is one of them. 

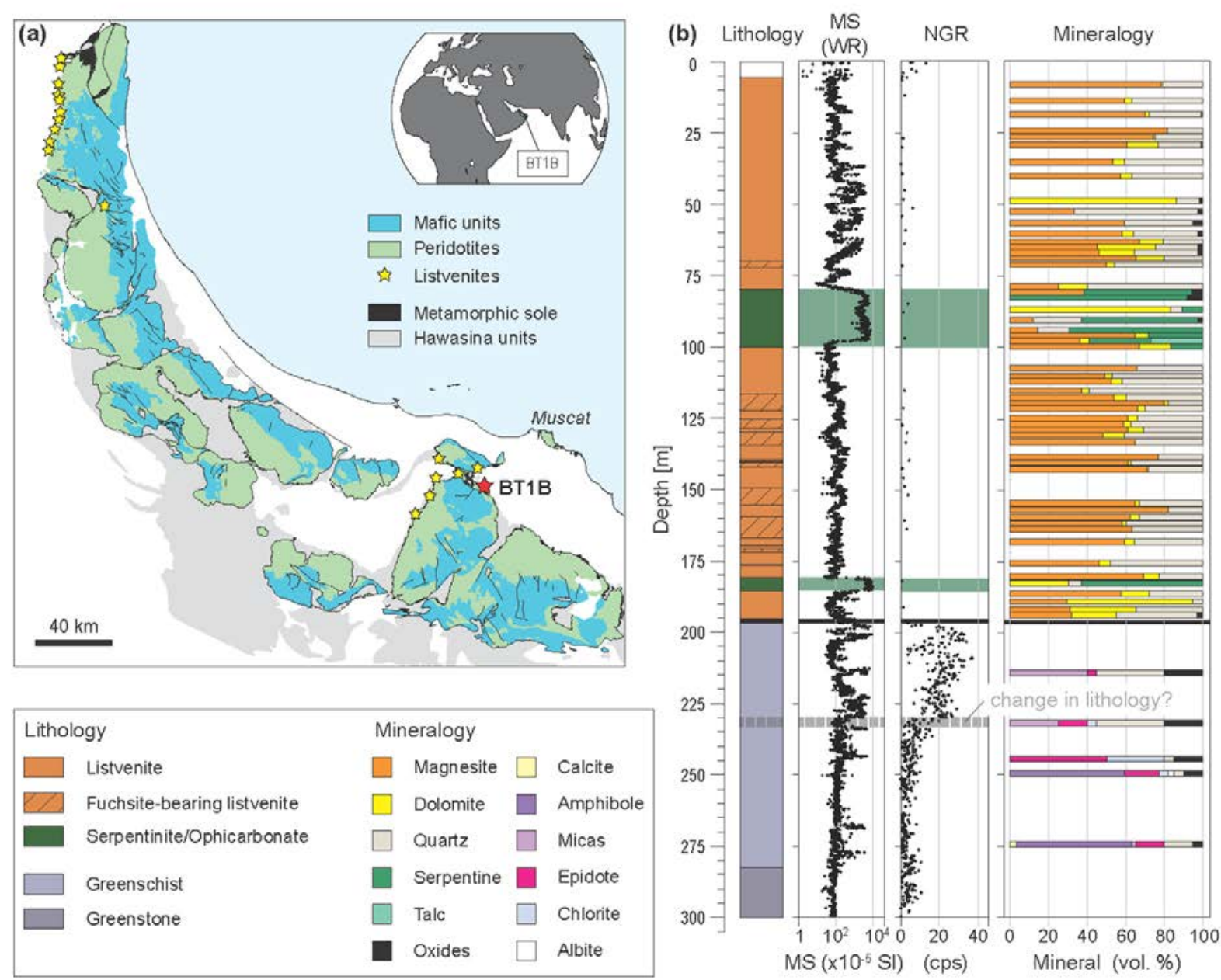

Figure 1. Location and downhole plots of lithological and physical properties of OmanDP Hole BT1B. (a) Simplified geological map of the Semail ophiolite. Yellow and red stars represent regional occurrences of listvenites and the location of OmanDP Hole BT1B, respectively (after Boudier and Nicolas [2018]); (b) Downhole plots of drilled lithologies, magnetic susceptibility (MS), natural gamma rays (NGR), and mineral proportions (data from Kelemen et al [2020]); mineral proportions are estimated based on thin section observations and $X$-ray diffraction analysis.

The Semail ophiolite is a fragment of Tethyan oceanic lithosphere tectonically emplaced on the Arabian plate at the end of the Cretaceous (Fig. 1a). Listvenite bodies occasionally crop out along its basal thrust ([Falk and Kelemen, 2015; Glennie et al., 1974; Nasir et al., 2007]; Fig. 1a). In 2017, a 300m long section was drilled through one of the largest bodies, north of Wadi Mansah (Fanjah, Sultanate of Oman; Fig 1a), as part of the ICDP Oman Drilling Project (OmanDP [Kelemen et al., 2020] ). OmanDP Hole BT1B sampled the transition from a sequence of listvenites and variously carbonated serpentinites, through the basal thrust of the ophiolite, to its metamorphic sole (Fig. 1b). This sampling allows us (i) to quantify the geochemical variations associated with the broad and complex range of mineralogy and rock types that are typical of listvenite suites and (ii) for the first time, to correlate these variations with the distance to a major pathway for the fluids triggering their formation, here the basal thrust. 
We carried out a bulk rock geochemical study (major, volatile and trace elements) of 84 samples representative of the different lithologies recovered at OmanDP Hole BT1B. Our results enable us to document the bulk composition of these different lithologies and their downhole variations from the sample scale to that of the borehole. This provides important new insights into the composition of the protolith of the Semail listvenite series and of the underlying metamorphic lithologies, and highlights the magnitude of fluid-mediated elemental transfers associated with the formation of listvenites along the basal thrust and into the overlying ophiolitic mantle.

\section{Geological Setting}

\subsection{The Semail Ophiolite}

The Semail ophiolite is composed of a dozen structural massifs outcropping over $500 \mathrm{~km}$ along the north-eastern margin of the Arabian Plate $\left(\sim 20000 \mathrm{~km}^{2}\right)$; it is regarded as one of the world's largest and best documented ophiolites (Fig 1a, [Boudier and Nicolas, 1988; Coleman and Hopson, 1981; Goodenough et al., 2010; Lippard et al., 1986; Peters et al., 1991; Searle, 2019]). The 5-7 km thick structural massifs were initially more than $12-15 \mathrm{~km}$ thick according to structural reconstitutions, and expose continuous fragments of the Tethyan oceanic lithosphere: the ophiolitic sequence comprises a thick mantle section overlain by a well preserved layered oceanic crust, from lower gabbros to upper volcanics [Lippard et al., 1986; Nicolas et al., 2000], formed at the end of the Cretaceous (96.1-95.2 Ma [Rioux et al., 2021]). The geochemistry of the upper volcanics indicates a transition from oceanic accretion to subduction related volcanism (e.g., [Belgrano et al., 2019; Ernewein et al., 1988; Godard et al., 2003]), that has been interpreted as evidence for a spontaneously initiating subduction (e.g., [MacLeod et al., 2013; Pearce et al., 1981]) or for a change in geodynamic settings, from mid-ocean ridge to intraoceanic underthrusting and/or incipient subduction (e.g., [Boudier et al., 1988; Godard et al., 2006; Goodenough et al., 2010]).

The mantle section is predominantly made up of moderately serpentinized (40-80\%) depleted harzburgites with minor dunites [Boudier et al., 2010; Godard et al., 2000; Hanghoj et al., 2010; Hopson et al., 1981], that preserve the microstructural fabric of asthenospheric deformation below the oceanic spreading center [Boudier and Coleman, 1981]. Low temperature ductile deformation overprints this early deformation towards the base of the mantle section and has been ascribed to the onset of the ophiolite detachment (e.g., [Boudier et al., 1988; Linckens et al., 2011; Nicolas et al., 2000]). Local occurrences of lherzolites (>5 \% clinopyroxene, Cpx) and Cpx-harzburgites ( $>2 \% \mathrm{Cpx}$ ) are also described in this lowermost mantle section, generally in massifs where the thickest mantle sections were preserved (e.g. Fizh [Takazawa et al., 2003]; Wadi Tayin [Godard et al., 2000; Hanghoj et al., 2010]) and/or close to areas where the ophiolitic metamorphic sole outcrops [Khedr et al., 2014]. These Cpx-rich basal peridotites have been interpreted as the result of variable melt extraction along the palaeoridge [Khedr et al., 2014; Le Mée et al., 2004; Monnier et al., 2006] or, alternatively, as due to refertilization reactions at the base of the oceanic mantle lithosphere during off-axis cooling or early intraoceanic thrusting [Godard et al., 2000; Lippard et al., 1986; Takazawa et al., 2003].

The ophiolite lies upon a series of underthrusted sheets of pelagic and turbidititic sediments, shelf carbonates, as well as volcanics, mainly of alkaline composition (sometimes referred to as Haybi volcanics) with minor transitional to tholeiitic components [Bechennec et 
al., 1990; Chauvet et al., 2011; Lippard et al., 1986; Maury et al., 2003]. These lithologies commonly grouped as the Hawasina assemblages - are the relicts of a wide oceanic basin (at least $540 \mathrm{~km}$ across), that formed during the breakup and thinning of the Arabian continental margin during Permian to Trias [Bechennec et al., 1990].

The ophiolite sensu stricto and the underlying allochtonous units were thrusted atop the Arabian platform during late Cretaceous (e.g., [Glennie et al., 1974; Searle and Malpas, 1980]). Slivers of the ophiolite metamorphic sole are preserved at the transition from the allochtonous units to the base of the ophiolite mantle section. They are locally overlain by a $<200 \mathrm{~m}$ thick (proto-)mylonitic "Banded Unit”, deformed parallel to the basal contact, comprising basal lherzolites (or Cpx-harzburgites) alternating with harzburgites and/or dunites; all being highly serpentinized [Lippard et al., 1986; Prigent et al., 2018b]. The Banded Unit peridotites preserve evidence of secondary amphibole formed at the expense of Cpx and their constituent minerals systematically display preferential enrichments in highly incompatible and fluid mobile elements [Khedr et al., 2013; Prigent et al., 2018a]. The sole is composed of slivers of metamorphosed mafic crust with subordinate metasediments and serpentinites stripped from/by the understhrusted lithosphere. It is characterized by an inverted metamorphic gradient, from low temperature (LT) greenschist facies at the base up to high temperature (HT) amphibolite/granulite facies at the upper contact with the ophiolite mantle [Ghent and Stout, 1981; Searle and Cox, 1999; Soret et al., 2017]. Geochronology indicates that peak HT metamorphism is only slightly younger than the ophiolite crustal sequence (96.16-94.82Ma [Rioux et al., 2016; Warren et al., 2005]) suggesting that the overlying mantle lithosphere was young and hot when the metamorphic sole formed.

Listvenites outcrop irregularly along the basal thrust of the the Semail Ophiolite, often as 2-50 m wide bodies within the highly altered ophiolitic and sedimentary mélange in contact with its metamorphic sole (Fig 1a; [Glennie et al., 1974; Nasir et al., 2007; Stanger, 1985; Wilde et al., 2002]). One of the largest listvenite bodies outcrops over $1 \times 2 \mathrm{~km}^{2}$ in the Wadi Mansah area (South of Muscat). It includes large lenses of serpentinites and marks the transition from mantle peridotites to underlying greenschist facies meta-basalts and silicic sediments [Falk and Kelemen, 2015; Villey et al., 1986]. This site was chosen to drill OmanDP Hole BT1B with the objective of sampling the transition from the ophiolite mantle section to its metamorphic sole.

\subsection{OmanDP Hole BT1B and sampling}

Drilling at OmanDP Hole BT1B $\left(23^{\circ} 21.861^{\prime} \mathrm{N}, 58^{\circ} 20.149^{\prime} \mathrm{E}\right)$ recovered 300.05 meters of continuous cores (diameter 63.5mm (HQ) down to $167.10 \mathrm{mbg}$ and $47.6 \mathrm{~mm}$ (NQ) below). The mineralogy, alteration and structure of the cores and their main physical and chemical properties were measured on-board drilling vessel D/V Chikyu on whole cores, core sections (Visual Core Description - VCD) and thin sections, and reported in the OmanDP proceedings [Kelemen et al., 2020]. The main characteristics of the cores are summarized thereafter.

Below a few meters of alluvial material, Hole BT1B drilled first through a series of listvenites interlayered with serpentinites (hereafter grouped as the listvenite series), then through the basal thrust at 197 meters below ground (mbg) and into the metamorphic sole (Fig. 1b).

Listvenites comprise dominantly magnesite \pm dolomite and quartz; they are characterized by their pale yellow to dark reddish brown color in hand specimen. They contain relicts of chromian spinel and of magnetite alignments indicating that their protolith was a serpentinized 
peridotite. Between $\sim 110$ and $182 \mathrm{mbg}$, fuchsite, a chromian mica $\left((\mathrm{K}, \mathrm{Na})(\mathrm{Al}, \mathrm{Cr}, \mathrm{Fe})_{2}(\mathrm{Si}, \mathrm{Al})_{3} \mathrm{O}_{10}(\mathrm{OH}, \mathrm{F})_{3}\right)$, is commonly observed; it occurs as light green quartzfuchsite intergrowths forming $\mathrm{mm}$ - to $\mathrm{cm}$-size green spots easily recognizable on hand samples. Listvenites are highly brecciated down to $\sim 80 \mathrm{mbg}$ and the presence of altered and fragmented veins and breccia, associated with occurrences of hematite and goethite, results in variable and sometimes high magnetic susceptibility (Fig. 1b).

Serpentinites have dark- to olive-green colors and high magnetic susceptibility values (Fig. 1b). They were recovered at $80.28-100.23 \mathrm{mbg}$ and 181.26-185.47 mbg. Serpentinites are foliated to massive, they comprise mesh texture serpentine (lizardite) delineated by magnetite and subordinate bastite. They are crosscut by abundant light-green to white veins of dolomite ( \pm magnesite) and serpentine with, locally, carbonates replacing the serpentine matrix. Variously carbonated serpentinites are distinguished from listvenites by the absence of quartz, but minor talc is found locally at $\sim 98-100 \mathrm{mbg}$, close to the contact with listvenites.

The metamorphic sole is composed of greenish, microcrystalline and finely laminated schists (197.6-282.88 mbg) and greenstone (below $282.88 \mathrm{mbg}$ ) interpreted during shipboard logging as metasediments and metabasalts respectively. It comprises epidote, chlorite, albite, quartz, titanite, with carbonate and/or muscovite in schists and blue-green amphibole and minor pumpellyite in greenstones. The contact with the listvenite series occurs at 196.56-197.6 mbg. This tectonic contact is a fault gouge mixed with clasts of highly fragmented, fine-grained, chlorite- and epidote-bearing rocks. It is characterized by a strong and sharp increase in the Natural Gamma Radiation values (NGR), jumping from on average $<1 \mathrm{cps}$ (counts/s) in the upper parts of Hole BT1B to $>30$ cps at the thrust, then gradually decreasing downhole over $~ 30$ $40 \mathrm{~m}$ to relatively homogeneous and low values (<5 cps) (Fig. 1b).

84 samples $\left(\sim 40 \mathrm{~cm}^{3}\right)$ were collected from Hole BT1B for bulk rock geochemical measurements. The VCD rock-names were used to designate geochemistry samples because of the high petrographic variability of the core, in particular for the samples from the listvenite series that typically comprised variable amounts of serpentine, carbonate and/or quartz veins. 51 listvenites, 14 serpentinites, and 19 greenshists and greenstones were analyzed. Every 20m, a sample was taken during the drilling operations, and 15 on-site samples were thus collected. During the description of the cores on board D/V Chikyu, 59 samples were selected by the shipboard science party as representative of the different lithologies recovered from Hole BT1B. 10 additional listvenites and serpentinites were selected from Sections C5704B-73Z-1 to -75Z-2 (180.01-186.945mbg) for on-shore studies (“consortium samples”).

\section{Methods}

The major element composition of BT1B samples was determined by X-ray fluorescence (XRF) on-board D/V Chikyu for the drillsite and shipboard samples and at GeoLabs (Ontario, Canada) for consortium samples. Total $\mathrm{H}_{2} \mathrm{O}$ and $\mathrm{CO}_{2}$ concentrations and abundances of inorganic carbon (total inorganic carbon, TIC) in the drillsite and shipboard samples were determined onboard D/V Chikyu by combustion CHNS elemental analysis (EA) and coulometry, respectively. The FeO concentration of a subset of samples (8 serpentinites and 21 Listvenites) was quantified at the University of Lausanne (ISTE) following the Fe-titration protocol of Wilson [1960]. The trace element composition ( $\mathrm{Li}, \mathrm{Sc}, \mathrm{Ti}, \mathrm{V}, \mathrm{Mn}, \mathrm{Co}, \mathrm{Ni}, \mathrm{Cu}, \mathrm{Ga}, \mathrm{As}, \mathrm{Sn}, \mathrm{Sb}, \mathrm{Rb}, \mathrm{Sr}, \mathrm{Y}, \mathrm{Zr}, \mathrm{Nb}, \mathrm{Cs}$, $\mathrm{Ba}$, Rare Earth Elements (REE), Hf, Ta, Pb, Th, U, W) of the drillsite, shipboard and consortium samples was analyzed by Inductively-Coupled-Plasma-Mass Spectrometry (ICP-MS) at 
Géosciences Montpellier (AETE-ISO Facility, University of Montpellier, France) using the protocol described in Godard et al. [2000]. The preparation of the samples and the analytical procedures are detailed in Supplementary Text S1.
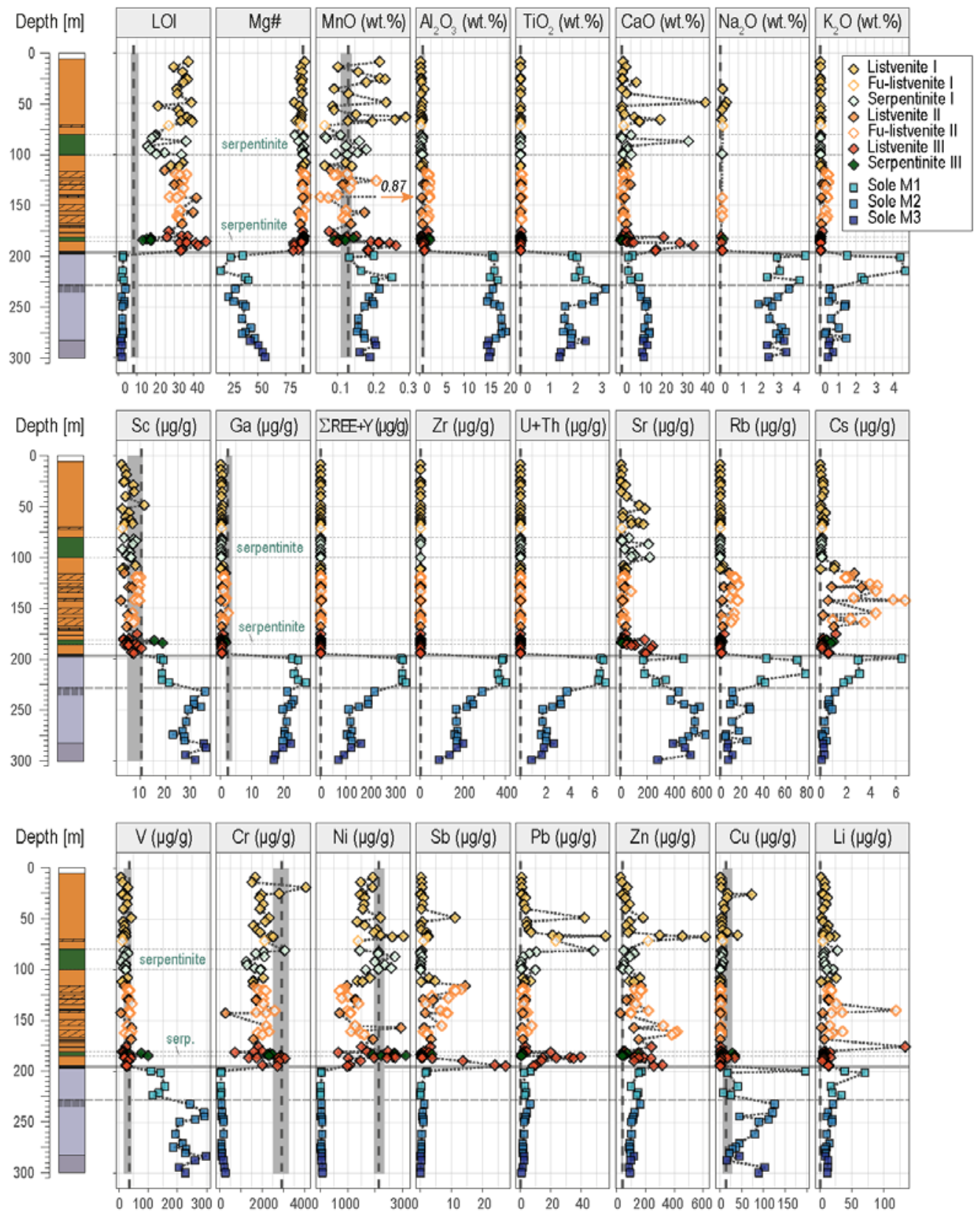

Figure 2. Concentrations of selected geochemical species plotted by depth downhole for all BT1B samples. Dashed line indicates the median concentration from literature data for peridotites from the main mantle section (MMS) of the Semail Ophiolite ( $n=92$; [Gerbert-Gaillard, 2002; Godard et al., 2000; Hanghoj et al., 2010]), and the grey field indicates \pm 1 standard deviation (calculated as the 16th and 84th percentile) about the median (Supplementary Table S2). Major oxides are plotted on a volatile free basis. Symbols are in inset. Listvenites, fuchsite-bearing listvenites (Fu-listvenites), serpentinites and ophicarbonates (grouped as Serpentinites) from Listvenite domains I, II and III are noted I, II and III respectively. Samples from the metamorphic sole (noted sole) are grouped as M1, M2 and M3. 
The main lithological characteristics of the analyzed samples and their major, trace and volatile element concentrations are reported in Supplementary Dataset S1.

\section{Results}

The listvenite series and the underlying metamorphic sole are distinguished by significant downhole differences in the values of several geochemical indicators, such as loss on ignition (LOI), Mg\# (100 x molar ( $\mathrm{Mg} /(\mathrm{Mg}+\mathrm{Fe})$, with all $\mathrm{Fe}$ as $\left.\mathrm{Fe}^{2+}\right), \mathrm{Al}_{2} \mathrm{O}_{3}$ and trace element contents as illustrated on Figs. 2 and 3. These variations allow us to discriminate several lithological and geochemical domains along Hole BT1B.

\subsection{Geochemistry of the listvenite series (depth: 6.02-196.56 mbg)}

The listvenite series are characterized by high LOI (13.1-46.8 wt.\%), high Mg\# ( 90), high concentrations in transition metals such as Ni (up to $3110 \mu \mathrm{g} / \mathrm{g}$ ), Co (up to $128 \mu \mathrm{g} / \mathrm{g}$ ) and $\mathrm{Cr}$ (up to $4050 \mu \mathrm{g} / \mathrm{g}$ ), low concentrations in $\mathrm{Al}_{2} \mathrm{O}_{3}$ (<2 wt.\%), $\mathrm{Na}_{2} \mathrm{O}\left(\sim 0.1\right.$ wt.\%) and $\mathrm{TiO}_{2}(<0.1$ wt.\%) and in incompatible lithophile trace elements, such as Th $(<<0.005 \mu \mathrm{g} / \mathrm{g}), \mathrm{REE}(\Sigma \mathrm{REE}<1$ $\mu \mathrm{g} / \mathrm{g}$ ) and high field strength elements (HFSE, e.g., Zr $0.1 \mu \mathrm{g} / \mathrm{g}$ ). These compositions are highly variable downhole at the sample- to the meter scale yet they overlap, on average, that of the Semail ophiolite mantle (Figs. 2-5).

Volatile elements dominate the composition of the listvenite series. Listvenites have high $\mathrm{CO}_{2}$ indicative of the predominance of carbonates ( $\mathrm{LOI}>21.2 \mathrm{wt} . \%$; $\mathrm{CO}_{2}=21.3-43.2 \mathrm{wt} . \%$ ) but no $\mathrm{H}_{2} \mathrm{O}$ ( $\sim$ wt.\%). Serpentinites display the highest $\mathrm{H}_{2} \mathrm{O}$ contents (up to 12.1 wt.\%), primarily hosted by serpentines, which structurally comprise $\sim 13$ wt.\% $\mathrm{H}_{2} \mathrm{O}$ [Deer et al., 1996], and they have the lowest LOI (down to $13.1 \mathrm{wt} \%$ ) and $\mathrm{CO}_{2}$ (down to $5.6 \mathrm{wt} . \%$ ) values. Carbonate-rich serpentinites have intermediate compositions with LOI up to $36.1 \mathrm{wt}$ \%, $\mathrm{CO}_{2}$ up to $33.1 \mathrm{wt} . \%$ and $\mathrm{H}_{2} \mathrm{O}$ as low as 0.3 wt.\%. As the shipboard coulometry protocol does not allow the complete dissolution of magnesite (see Supplementary Text S1), only the samples in which dolomite is the dominant carbonate species have similar TIC and total carbon values. Most of these samples are serpentinites $\left(\mathrm{CO}_{2 \text { (TIC) }}\right.$ up to $33.3 \mathrm{wt}$ \%; $\mathrm{CO}_{2(\mathrm{TIC})}$ : TIC recalculated as $\left.\mathrm{CO}_{2}\right)$.

Aside from volatile elements, the listvenite series are composed mainly of $\mathrm{Si}, \mathrm{Mg}, \mathrm{Fe}$ and Ca: these elements calculated as oxides represent $\sim 99 \%$ of the samples volatile-free mass. Their distribution correlates primarily to the dominant mineralogy of the core (Fig. 4a): variations in $\mathrm{SiO}_{2}$ (4.4-70 wt.\%) reflect changes in carbonate/quartz ratios in listvenites, and in carbonate/serpentine ratios in serpentinites, while downhole spikes in $\mathrm{CaO}$ (up to $32.8 \mathrm{wt} \%$ in the serpentinites and up to 40.9 wt.\% in listvenites) correspond to increasing TIC values ( $\mathrm{CO}_{2 \text { (TIC) }}$ up to $40.1 \mathrm{wt}$ \% in listvenites), indicative of the presence of dolomite (Fig. 1; [Kelemen et al., 2020]). Correlations with these main mineralogical changes are more difficult to identify for $\mathrm{Mg}$, Fe and Mg\#, except for local decreases in $\mathrm{MgO}$ and $\mathrm{Mg \#}$ associated with high $\mathrm{CaO}$ and TIC contents in dolomite-rich samples (e.g. listvenite C5704B-23Z-1-1,37.0--42.0cm at 48.72 mbg; Figs. 2-3). In contrast, $\mathrm{Al}_{2} \mathrm{O}_{3}$, transition metals (e.g., Ti, $\mathrm{Ni}$ and $\mathrm{Co}$ ) and lithophile trace elements (e.g., REE, Y) do not correlate with changes in volatile chemistry nor in the distribution of the dominant minerals: in particular, we do not observe major changes in their distribution between listvenites and serpentinites. These elements, generally considered as fluid-immobile, display coherent tens of meter scale downhole trends that allow us to define three geochemical domains (Figs. 3-5), thereafter described as, from top to bottom, listvenite domains I, II and III. 

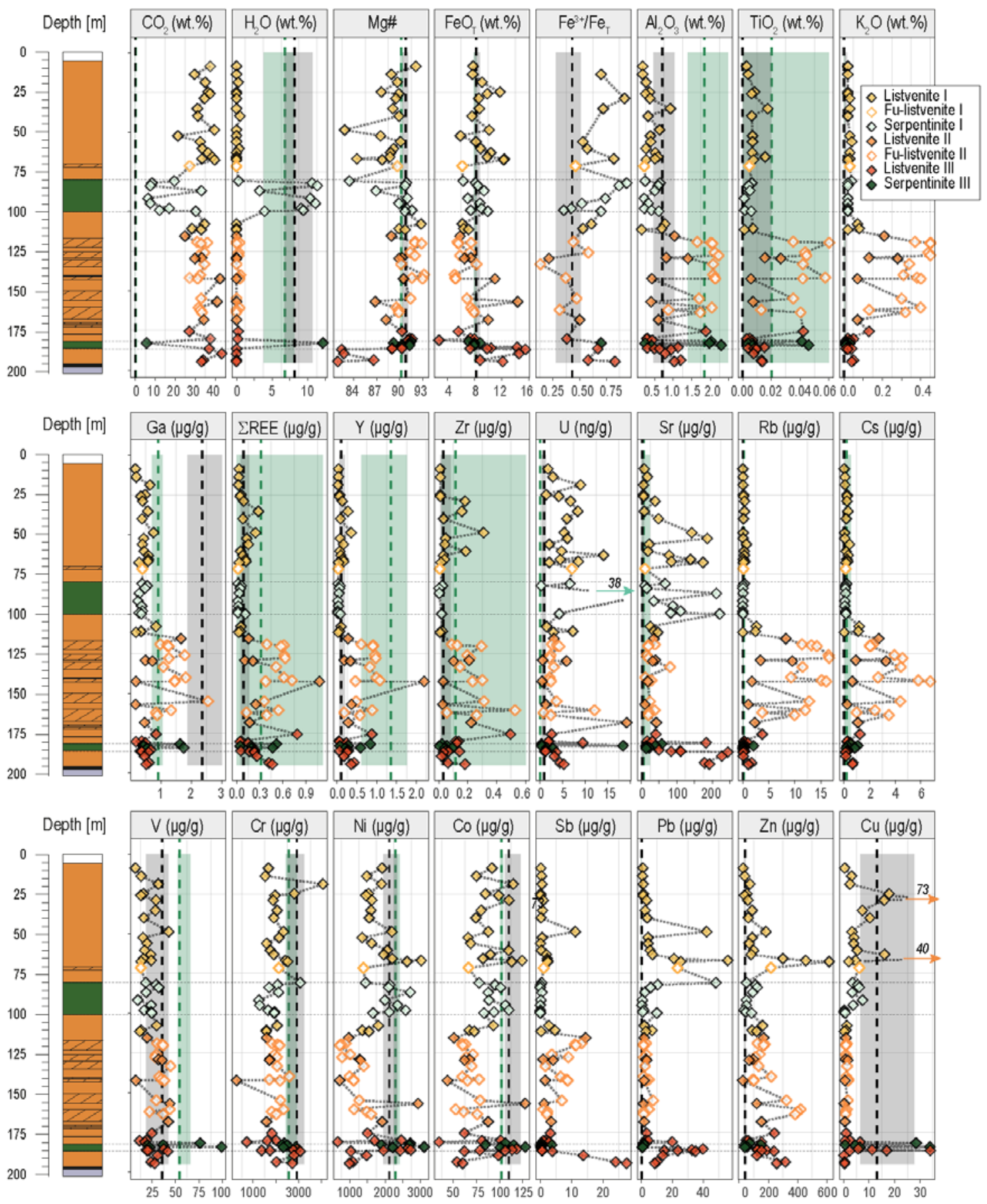

Figure 3. Concentrations of selected geochemical species plotted by depth downhole for BT1B listvenite series. Dashed grey and green lines indicate the median concentration from literature data for the MMS peridotites ( $n=92)$ and basal lherzolites ([Lippard et al., 1986; Takazawa et al., 2003]; $n=13)$ of the Semail ophiolite, respectively. Fields of the corresponding color indicate \pm 1 standard deviation (calculated as the 16th and 84th percentile) about the median (Supplementary Table S2). Symbols for are in inset, abbreviations are as in Figure 2. 
Listvenite domain I (top to 112 mbg) comprises listvenites (listvenites I), including one fuchsite-bearing listvenite, and serpentinites (serpentinites I). It is characterized by low concentrations in $\mathrm{Al}_{2} \mathrm{O}_{3}$ (0.14-0.92 wt.\%), $\mathrm{TiO}_{2}\left(<0.01\right.$ wt.\%) and trace elements (e.g. $\mathrm{Yb}_{\mathrm{N}}=0.03-$ 0.22; N=normalized to CI-Chondrite [McDonough and Sun, 1995]) that overlaps that of the harzburgites and dunites from the main mantle section (MMS) of the Semail ophiolite [Godard et al., 2000; Hanghoj et al., 2010; Lippard et al., 1986]. It displays relatively linear REE patterns similar to that of the MMS, with normalized REE abundances decreasing from heavy (HREE) to light REE (LREE) $\left((\mathrm{Ce} / \mathrm{Yb})_{\mathrm{N}}=0.08-0.54\right)$. Several samples, in particular the serpentinites and ophicarbonates, present minor LREE enrichments relative to middle REE (MREE) (e.g., carbonate rich serpentinite C5704B-44Z-4, 50.0-55.0 cm with $\left.(\mathrm{La} / \mathrm{Sm})_{\mathrm{N}}=3.7\right)$, similar to what is observed in some Ca-bearing carbonates from oceanic and ophiolitic peridotite hosted low temperature hydrothermal systems [Noel et al., 2018; Schroeder et al., 2015].

Listvenite domain II ( 112 mbg to $\sim 170 \mathrm{mbg}$ ) is composed of listvenites alternating with fuchsite-bearing listvenites (all grouped as listvenites $I I$ ). It is characterized by elevated concentrations in $\mathrm{Al}_{2} \mathrm{O}_{3}$ (0.4-2.23 wt.\%) and $\mathrm{TiO}_{2}$ (0.02-0.06 wt.\%) compared to Listvenite domain I. This domain has higher lithophile trace element contents (e.g. $\mathrm{Yb}_{\mathrm{N}}=0.18-1.03$ ) and highly fractionated "spoon-shaped" REE patterns $\left((\mathrm{Ce} / \mathrm{Yb})_{\mathrm{N}}=0.007-0.061\right)$ with relatively flat convex-upward MREE-HREE segments $\left((\mathrm{Dy} / \mathrm{Yb})_{\mathrm{N}}=0.49-0.96\right)$ and slight but systematic enrichments of La relative to $\mathrm{Ce}\left((\mathrm{La} / \mathrm{Ce})_{N}=1.03-4.9\right)$, comparable to that of the (amphibolebearing) basal lherzolites from the northern Semail ophiolite (Figs. 4-5; [Khedr et al., 2014; Takazawa et al., 2003]). These REE patterns are very similar in shape to those obtained by Prigent et al [2018a] on clinopyroxene and amphibole from the Banded Unit lherzolites close to the metamorphic sole. Listvenite domain II is also distinguished by, on average, low Ni ( 1200 $\mu \mathrm{g} / \mathrm{g})$ and $\mathrm{Co}(\sim 68 \mu \mathrm{g} / \mathrm{g})$ concentrations and low $\mathrm{Fe}^{3+} / \mathrm{Fe}_{\mathrm{TOT}}(0.1-0.6)$ compared to Lisvenite domain I (Ni 1900 $\mu \mathrm{g} / \mathrm{g}$; Co 90 $\left.\mu \mathrm{g} / \mathrm{g} ; \mathrm{Fe}^{3+} / \mathrm{Fe}_{\mathrm{TOT}} \sim 0.7\right)$.

Figure 4 (Next page). Scatterplots of the composition of BT1B samples. Listvenite series are plotted on (a) $\left(\mathrm{XMg}+\mathrm{XFe}\right.$ ) versus $\mathrm{XSi}\left(\mathrm{X}=\right.$ cation molar proportion), (b) $\mathrm{TiO}_{2}$ (wt.\%) versus $\mathrm{Al}_{2} \mathrm{O}_{3}$ (wt.\%), (c) Chondrite normalized $(\mathrm{La} / \mathrm{Sm})$ versus $(\mathrm{Dy} / \mathrm{Yb})$ diagrams. The metamorphic sole is plotted on (d) $\mathrm{TiO}_{2}$

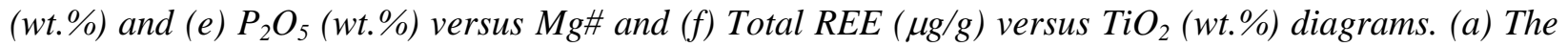
composition of listvenite series are compared to that of the refractory peridotites from the Semail Ophiolite (white field), magnesite, dolomite, quartz, talc, lizardite and olivine [Deer et al., 1996], and the mean composition of listvenite series (black circle) also, recalculated as Ca free (white circle). (b) $\mathrm{TiO}_{2}$ and $\mathrm{Al}_{2} \mathrm{O}_{3}$ are plotted on a volatile-free basis and, when available, recalculated ICPMS data was used for plotting $\mathrm{TiO}_{2}$. The composition of depleted mantle (DM [Salters and Stracke, 2004]), primitive mantle (PM [McDonough and Sun, 1995]) and/or literature data from the Semail mantle (MMS [GerbertGaillard, 2002; Godard et al., 2000; Hanghoj et al., 2010], basal lherzolites [Lippard et al., 1986; Takazawa et al., 2003] and amphibole bearing basal lherzolites - Basal amph. lherzolites [Khedr et al., 2014]) and listvenites [Falk and Kelemen, 2015] are shown for comparison on (a), (b) and (c). The composition of Permian and Triassic volcanics ([Chauvet et al., 2011; Lapierre et al., 2004; Lippard et al., 1986; Maury et al., 2003]) and sediments [Oberhänsli et al., 1999] from the underthrusted Hawasina nappes, and of amphibolites and metasediments from the metamorphic sole [Ishikawa et al., 2005] are shown for comparison on (d), (e) and (f). Symbols are in legend, abbreviations are as in Figure 2. 

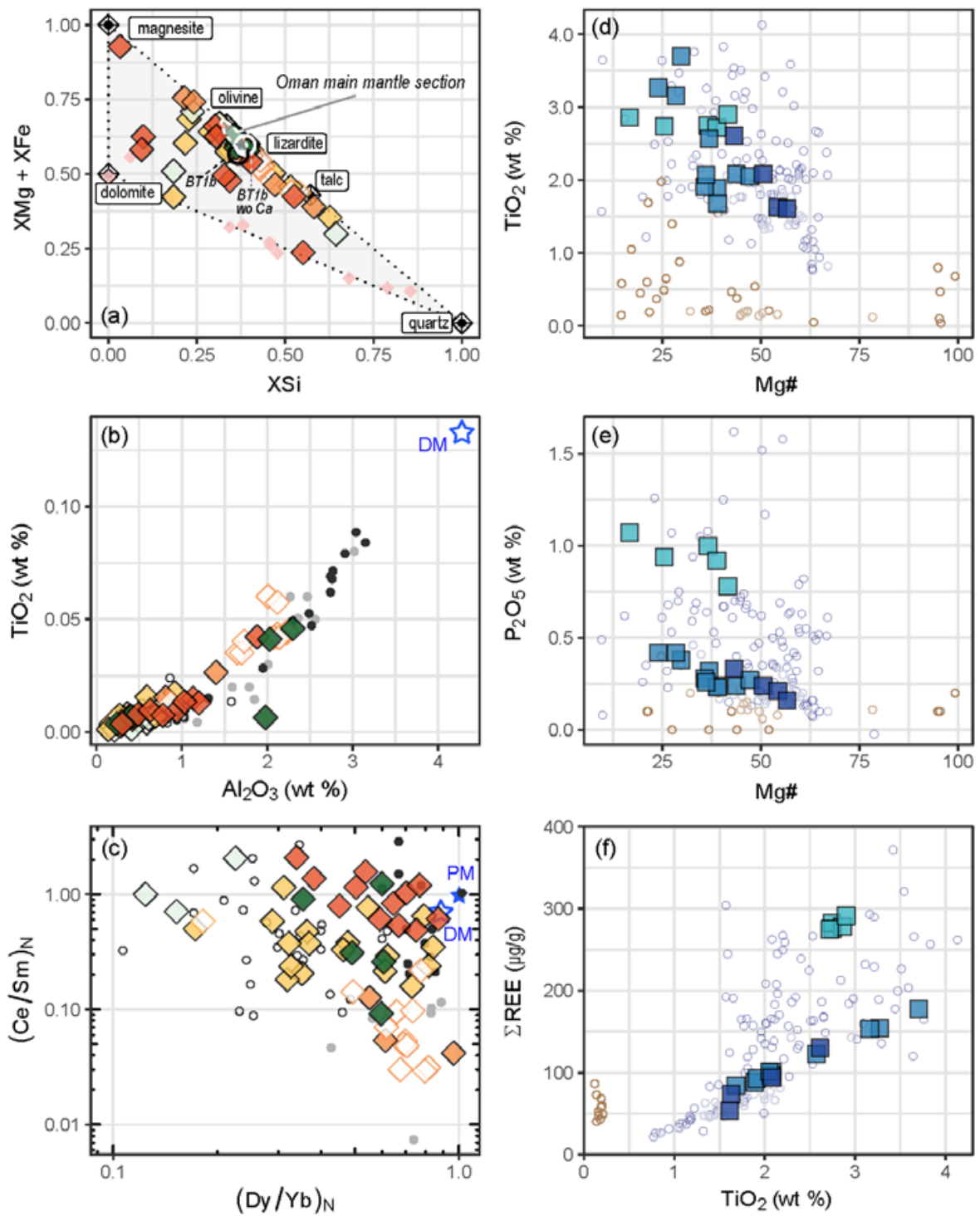

\begin{tabular}{|ll}
\hline Hole BT1B & \\
$\diamond$ Listvenite I & $\diamond$ Serpentinite I \\
$\diamond$ Fu-listvenite I & $\diamond$ Serpentinite III \\
$\diamond$ Listvenite II & $\square$ Sole M1 \\
$\diamond$ Fu-listvenite II & $\square$ Sole M2 \\
$\diamond$ Listvenite III & $\square$ Sole M3
\end{tabular}

Semail ophiolite

- MMS

- Basal Iherzolites

Metamorphic Sole

- Amphibolites

- Basal amph. Iherzolites

Metasediments

Listvenites

Hawasina Nappes

- Volcanics

○ Sediments

Listvenite domain III ( $170 \mathrm{mbg}$ to the basal thrust) is the closest to the metamorphic sole. It comprises listvenites (listvenites III) and serpentinites (serpentinites III). It has concentrations in $\mathrm{Al}_{2} \mathrm{O}_{3}\left(0.24-2.30\right.$ wt.\%), $\mathrm{TiO}_{2}\left(<0.02\right.$ wt.\%) and trace elements (e.g. $\mathrm{Yb}_{\mathrm{N}}=0.05-$ 0.77) intermediate between that of the Lisvenite domains I and II, the most enriched samples being serpentinites and listvenites close to Listvenite domain II. It displays linear REE patterns comparable to that of Lisvenite domain I $\left((\mathrm{Ce} / \mathrm{Yb})_{N}=0.08-0.67\right)$ with the exception of some samples close to Listvenite domain II that have similarly fractionated REE patterns $\left((\mathrm{Ce} / \mathrm{Yb})_{\mathrm{N}}=0.011-0.163\right)$. Listvenite domain III is characterized by systematic enrichments in 
LREE relative to MREE $\left((\mathrm{La} / \mathrm{Sm})_{\mathrm{N}}=0.34-3.29\right)$, a trend that overall increases towards the basal thrust. This downhole trend is accompanied by a decrease in $\mathrm{Mg \#} \mathrm{(down} \mathrm{to} \mathrm{82),} \mathrm{an} \mathrm{increase} \mathrm{in}$ $\mathrm{Fe}^{3+} / \mathrm{Fe}_{\text {Tот }}$ up to Listvenite domain I values (0.38-0.83) and an increasingly scattered distribution of several elements such as $\mathrm{Ni}(650-3100 \mu \mathrm{g} / \mathrm{g})$ and $\mathrm{Co}(35-128 \mu \mathrm{g} / \mathrm{g})$, or $\mathrm{Cu}(0.2-34 \mu \mathrm{g} / \mathrm{g})$ and $\mathrm{Pb}(0.5-39.7 \mu \mathrm{g} / \mathrm{g})$ as well as a progressive increase in the concentrations of $\mathrm{CaO}$ (up to 35.1 wt.\%), Sr (up to $244.3 \mu \mathrm{g} / \mathrm{g}$ ) and Sb (up to $27.4 \mu \mathrm{g} / \mathrm{g}$ ). These variations are associated with an increase in the dolomite fraction towards the basal thrust (Fig. 1b).

The listvenite series display spiked U-shaped trace element patterns that reflect the relative depletion of $\mathrm{Zr}-\mathrm{Hf}$ relative to neighboring elements and significant enrichments in incompatible fluid mobile elements (FME), such as alkali elements (Cs, Rb, Ba), $\mathrm{Li}, \mathrm{Sb}, \mathrm{U}, \mathrm{Pb}$ and Sr relative to Th, Nb, Ta and LREE (Fig. 5). These strong FME enrichments distinguish the listvenite series from the MMS harzburgites and dunites (Figs. 2, 3 and 5). High FME concentrations appear as spikes on downhole plots (Fig. 3). These spikes are however located preferentially in well-defined listvenite domains for most elements with a decoupling in the downhole distribution of alkali elements and other FME such as $\mathrm{Sb}, \mathrm{Pb}, \mathrm{Sr}$ and $\mathrm{U}$. High concentrations of alkali elements including $\mathrm{K}_{2} \mathrm{O}$ (0.07-0.45 wt.\%), Ba (up to $420 \mu \mathrm{g} / \mathrm{g}$ ), Rb (1.1$17 \mu \mathrm{g} / \mathrm{g}$ ) and Cs $(0.24-6.8 \mu \mathrm{g} / \mathrm{g})$ distinguish Listvenite domain II from Listvenite domains I and III $\left(\mathrm{K}_{2} \mathrm{O}=0.02-0.08 \mathrm{wt} . \% ; \quad \mathrm{Rb}=0.006-2.6 \mu \mathrm{g} / \mathrm{g} ; \quad \mathrm{Cs}=0.02-1.19 \mu \mathrm{g} / \mathrm{g}\right)$, with the highest concentrations in fuchsite-bearing listvenites. In contrast, downhole spikes in concentrations for $\mathrm{Pb}, \mathrm{Sr}$ and $\mathrm{U}$ are mainly in Listvenite domains I and III ( $\mathrm{Pb}$ up to $56 \mu \mathrm{g} / \mathrm{g}$, Sr up to $244 \mu \mathrm{g} / \mathrm{g}$, U up to $0.04 \mu \mathrm{g} / \mathrm{g}$ ). $\mathrm{Cu}$ (up to $73 \mu \mathrm{g} / \mathrm{g}$ ) and to a lesser extent, Sb (up to $27.4 \mu \mathrm{g} / \mathrm{g}$ ) and $\mathrm{Zn}$ (up to $610 \mu \mathrm{g} / \mathrm{g}$ ) display similar trends with peaks in concentrations mainly in Listvenite domains I and III.

Some elements are characterized by highly scattered distributions and concentrations, and their compositions overlaps with that of the metamorphic sole (e.g., $\mathrm{Li}=2.5-134 \mu \mathrm{g} / \mathrm{g}$ in listvenite series and 8-70 $\mu \mathrm{g} / \mathrm{g}$ in metamorphic rocks; Fig. 2). Some of these extreme variations can be correlated on a case-by-case basis to lithological or structural features as for MnO-rich sample C5704B-60Z-4-1,24.0--29.0 cm(V) ( $\mathrm{MnO}=0.87 \mathrm{wt} . \%)$ identified as a listvenite vein crosscutting a fuchsite-bearing listvenite (C5704B-60Z-4-1,24.0--29.0 $\mathrm{cm}(\mathrm{H})$ ). This sample is also the most enriched in REE and Y (e.g., Y=2.2 $\mu \mathrm{g} / \mathrm{g})$ and the most depleted in $\mathrm{Cr}(271 \mu \mathrm{g} / \mathrm{g})$ indicating extensive elemental redistribution occurring at the sample scale.

\subsection{Geochemistry of the metamorphic sole (depth: 196.56- $300.13 \mathrm{mbg}$ )}

BT1B metamorphic rocks have LOI of 1.3-3.8 wt.\% related to the presence of $\mathrm{H}_{2} \mathrm{O}(>2$ wt.\%) in hydrous minerals (chlorite, amphibole ...) and minor $\mathrm{CO}_{2}(0.04-0.97$ wt.\%) in carbonates, mainly calcite $\left(\mathrm{CO}_{2 \text { (TIC) }}\right.$ 0.01-0.95 wt.\%). They have low Mg\# (16.7-56.6), low concentrations of $\mathrm{Cr}(42-265 \mu \mathrm{g} / \mathrm{g})$ and $\mathrm{Ni}(15-86 \mu \mathrm{g} / \mathrm{g})$ and high concentrations of $\mathrm{Al}_{2} \mathrm{O}_{3}$ (15.219.4 wt.\%), $\mathrm{Na}_{2} \mathrm{O}$ (2.1-4.7 wt.\%), $\mathrm{P}_{2} \mathrm{O}_{5}\left(0.16-1.07\right.$ wt.\%) and $\mathrm{TiO}_{2}$ (1.6-3.7 wt.\%) and they display a relatively narrow range of $\mathrm{SiO}_{2}$ concentrations (44.5-52.6 wt.\%). They are characterized by high concentrations of V (110-297 $\mu \mathrm{g} / \mathrm{g})$ and of incompatible trace elements, such as Th $(0.75-5.9 \mu \mathrm{g} / \mathrm{g})$, REE ( $(\mathrm{REE}=54-291 \mu \mathrm{g} / \mathrm{g}$ ) and HFSE (e.g., Nb=9.5-63 $\mu \mathrm{g} / \mathrm{g})$, and by LREE-enriched chondrite-normalized REE patterns $\left((\mathrm{Ce} / \mathrm{Yb})_{\mathrm{N}}=3.4-8.2\right)$. They overlap in composition with the amphibolites from the Semail ophiolite metamorphic sole [Ishikawa et al., 2005; Lippard et al., 1986] and the volcanic rocks from the underthrusted Hawasina assemblages 
[Chauvet et al., 2011; Lapierre et al., 2004; Maury et al., 2003] (Figures 4-5). They display trace element compositions similar to the transitional to alkali basalt series forming the HawasinaHaybi complex indicating that the BT1B metamorphic rocks comprise only metabasalts.
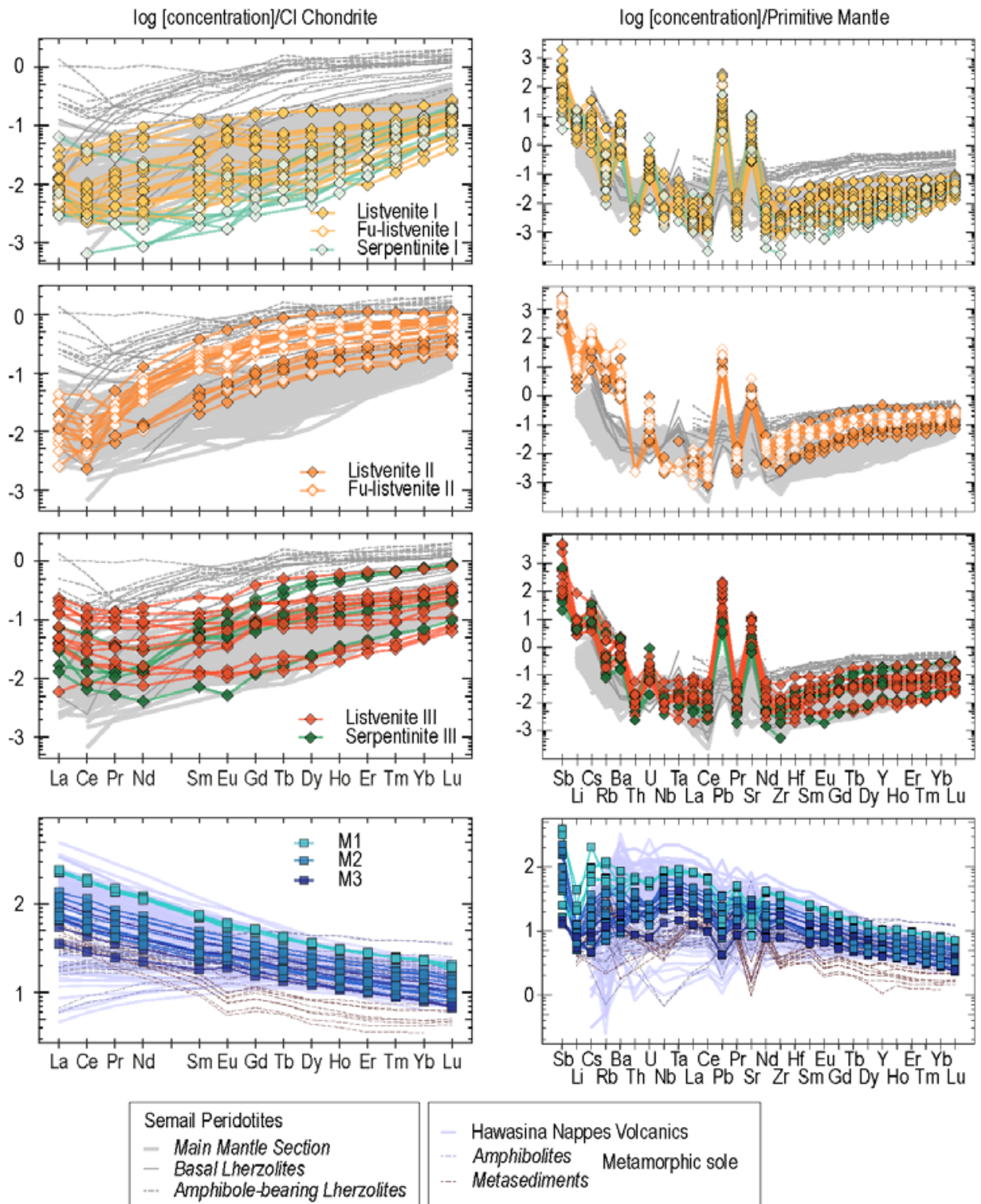

Figure 5. Rare-earth element (REE) and trace element spider diagrams for BT1B samples. Separate panels are plotted for Listvenite domains I, II and III, and for the metamorphic sole. Left: CI chondritenormalized REE patterns. Right: Primitive mantle-normalized trace element plots; normalizing values from McDonough and Sun [1995]. Literature data from Semail Ophiolite peridotites are plotted for reference in the upper three panels, and from metamorphic sole and Hawasina nappes in the lowermost panel (references in caption of Figure 4). Symbols are in inset and legend beneath the plots, abbreviations are in Figure 4.

We have subdivided Hole BT1B metamorphic rocks into three groups based on their lithology, physical properties, geochemistry and depth (Fig. 3). 
The first group (M1) corresponds to the high NGR cores (197.6- 230 mbg; Fig. 1b). It represents the most enriched endmember of BT1B metabasalts for $\mathrm{P}_{2} \mathrm{O}_{5}$ (0.78-1.07wt.\%), alkali elements ( $\left.\mathrm{K}_{2} \mathrm{O}=1.5-4.7 w t . \% ; \quad \mathrm{Ba}=192-598 \mu \mathrm{g} / \mathrm{g} ; \mathrm{Rb}=37-78 \mu \mathrm{g} / \mathrm{g} ; \mathrm{Cs}=1.9-6.5 \mu \mathrm{g} / \mathrm{g}\right)$ and moderately to highly incompatible lithophile elements, such as REE ( $\left.\mathrm{Yb}_{\mathrm{N}} \sim 23\right)$, Th (5.1-5.9 $\left.\mu \mathrm{g} / \mathrm{g}\right)$ and $\mathrm{U}(1.0-1.3 \mu \mathrm{g} / \mathrm{g})$. They have however middle range values for transition elements $\mathrm{TiO}_{2}$ (1.92.4wt.\%), V (110-157 $\mu \mathrm{g} / \mathrm{g})$ and Sc (17.9-21.3 $\mu \mathrm{g} / \mathrm{g})$. They are overall depleted in CaO (3.959.1wt.\%) and in Sr (173-342 $\mu \mathrm{g} / \mathrm{g})$ although these elements increase with depth. $M 1$ metabasalts display the most fractionated REE patterns $\left((\mathrm{Ce} / \mathrm{Yb})_{\mathrm{N}}=7.7-8.2\right)$ as well as slight enrichments in $\mathrm{Nb}-\mathrm{Ta}$ (e.g. $\mathrm{Nb} / \mathrm{Th} 1.27 \mathrm{xPM}$ ), and negative anomalies in $\mathrm{Pb}$ and $\mathrm{Sr}$ relative to neighboring elements (Pb/Ce 0.25xPM; Sr/Ce 0.2xPM) on extended trace element diagrams (Fig. 5). Their high concentrations in K, Th and U likely explain their high NGR values (Fig.1).

The second and third groups, M2 ( 230-282.88 mbg) and M3 (below $282.88 \mathrm{mbg}$ ) are composed of schists and greenstones respectively. The downhole transition from $M 1$ to M2-M3 metabasalts is characterized by a sharp decrease in $\mathrm{K}_{2} \mathrm{O}$, and Rb, REE, HFSE, Th and $\mathrm{U}$ and a sharp increase in $\mathrm{TiO}_{2}$ (up to 3.7 wt.\%; Fig.2). M2-M3 metabasalts record a continuous downhole increase in Mg\# (up to 56.6), Sc (up to $36 \mu \mathrm{g} / \mathrm{g}$ ), $\mathrm{V}$ (up to $297 \mu \mathrm{g} / \mathrm{g}$ ), Co (up to 45 $\mu \mathrm{g} / \mathrm{g}$ ) and $\mathrm{Ni}$ (up to $87 \mu \mathrm{g} / \mathrm{g}$ ) and a decrease in alkali elements (e.g., $\mathrm{K}_{2} \mathrm{O}$ down to $0.3 \mathrm{wt} . \%$ ) and in moderately to highly incompatible lithophile elements (e.g., $\mathrm{TiO}_{2}$ down to 1.6 wt.\%; Th down to $0.7 \mu \mathrm{g} / \mathrm{g}$ ). They also show a progressive decrease in trace element concentrations and in LREE/HREE ratios with depth (Figs. 2, 4). Negative correlations between $\mathrm{TiO}_{2}, \mathrm{REE}$ and HFSE and $\mathrm{Co}$, Ni and Mg\# such as those observed downhole are typical of basaltic fractional crystallization trends with the lowermost $M 3$ metabasalts having the least evolved compositions. Finally M2-M3 metabasalts display positive anomalies in Nb-Ta (e.g. Nb/Th 1.5xPM), minor negative anomalies in $\mathrm{Pb}(\mathrm{Pb} / \mathrm{Ce}=0.43-0.88 \times \mathrm{PM})$ and variable $\mathrm{Sr}$ anomalies $(\mathrm{Sr} / \mathrm{Ce}=0.5-1.7 \times \mathrm{PM})$ relative to neighboring elements on extended trace element diagrams (Fig. 5). $\mathrm{CaO}$ and $\mathrm{Sr}$ downhole trends are decoupled from other elements: they increase then stabilize with depth in M2 (CaO up to 14.0 wt.\%; Sr up to $638 \mu \mathrm{g} / \mathrm{g}$ ) and decrease towards the bottom of the borehole (CaO down to 10.75 wt.\%; Sr down to $281 \mu \mathrm{g} / \mathrm{g}$ ).

\section{Discussion}

Drill cores recovered from at Hole BT1B provide the first high resolution sampling of the transition from the base of the Semail ophiolite to its metamorphic sole, thus allowing a detailed study of the geochemical processes occurring across this major tectonic structure. The mantlederived listvenite series comprise highly fractured and veined listvenites and fuchsite-bearing listvenites and two minor intervals of variously carbonated serpentinites. In spite of the complete transformation of their mineralogy due to $\mathrm{CO}_{2}$-metasomatism, the listvenite series preserve average compositions comparable to that of the highly serpentinized, often amphibole bearing, "Banded Unit" peridotites - a narrow zone atop the basal thrust and the metamorphic sole (Fig. 2-5, [Khedr et al., 2013; Khedr et al., 2014; Prigent et al., 2018a; Yoshikawa et al., 2015]). The greenschist facies BT1B metamorphic sole has basaltic compositions similar to that of the alkali metabasalts from the underthrusted Hawasina assemblages (Figures 4-5) from which they likely derive (e.g., [Searle and Malpas, 1980]). It displays progressively less evolved compositions away from the ophiolite contact (from $M 1$ to $M 3$ metabasalts), a characteristic previously documented in the amphibolitic sole ([Ishikawa et al., 2005]; Fig. 2). There is no compositional 
evidence of interlayered metasediments, in contradiction to what initially hypothesized for the BT1B cores [Kelemen et al., 2020].

Hereafter, we will use our new high resolution geochemical database to evaluate the mass and volume changes associated with the formation of the listvenite series and discuss elemental mobility during these processes and its linkages to the composition of the protolith(s) and neighboring lithologies, the localization of fluid pathways along the BT1B cores and the interplay between solute transport and reaction kinetics during $\mathrm{CO}_{2}$ metasomatism.
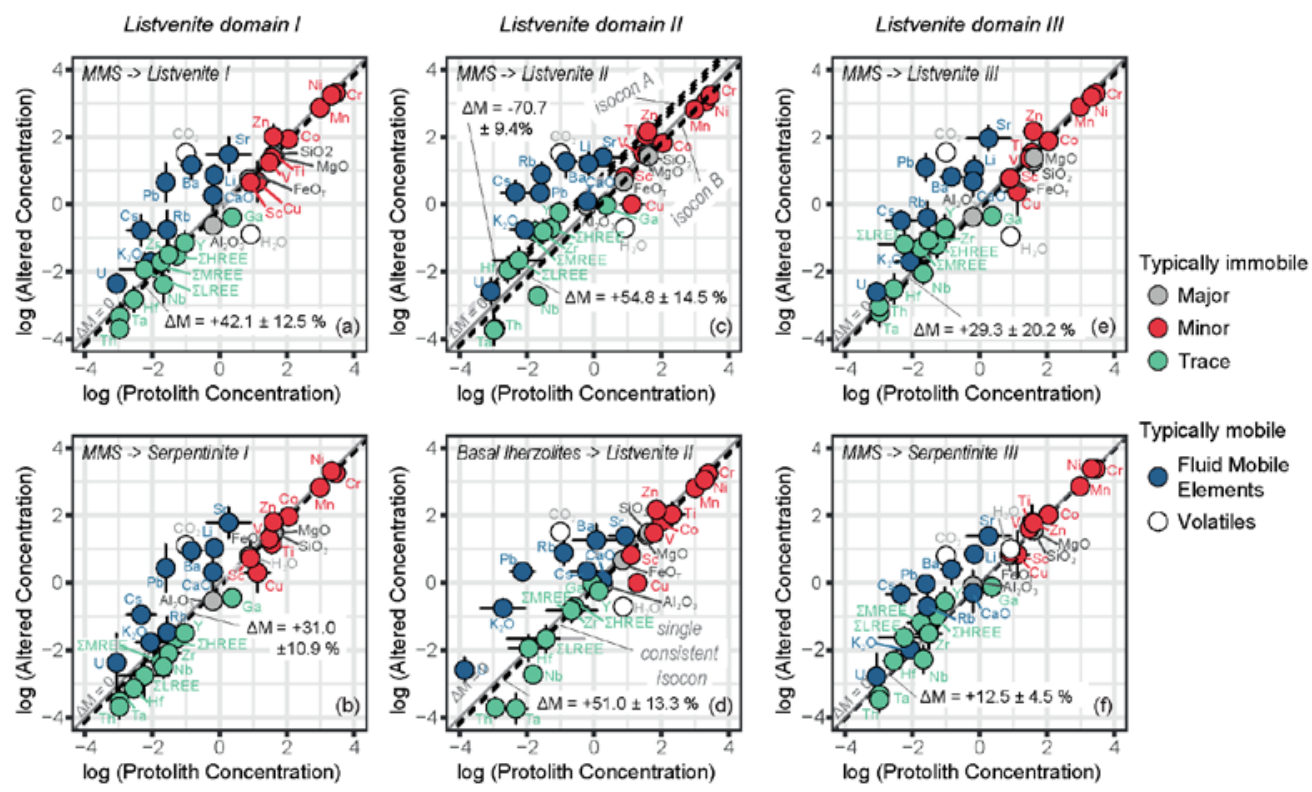

Figure 6. Mass balance diagrams for listvenite series from Hole BT1B. Isocon plots comparing the average composition of listvenites and serpentinites from each listvenite domains with potential protolith compositions on log-log scales. Isocons (line of immobility) were calculated using the approach of Baumgartner and Olsen [1995]. On each panel, the isocon (dotted black lines) corresponds to a protolith-altered rock pair. The grey 1:1 reference line corresponds to zero mass change during alteration. Isocons above and below this indicate mass loss and gain, respectively (noted $\triangle M$ ). Using the average composition of the MMS refractory peridotites as the protolith composition for each domain, this approach gives consistent patterns of mobile and immobile elements, with the exception of Listvenites II (panel c) where two potential isocons are apparent in the data (labeled A and B). Mass balance was repeated for Listvenite II with the average composition of basal (amphibole-bearing) lherzolites, which gives a single consistent isocon and similar patterns of mobility/immobility to the other panels. Compositions are plotted as concentrations in wt.\% for major and volatile elements and in $\mu \mathrm{g} / \mathrm{g}$ for trace elements. Compositions and calculated statistics are in Supplementary Table S3. Symbols are in legend.

\subsection{Mass changes and elemental mobility during listvenization}

To evaluate the respective contribution of the host rock and incoming metasomatic fluids(s) to the composition of the listvenite series and to constrain elemental mobility at the scale of the borehole, we used the mass balance model of Baumgartner and Olsen [1995], a model based on Grant [1986]. This approach allows us to evaluate the addition and removal of a broad range of chemical elements during the alteration of a protolith of known composition and the resulting mass changes, without a priori assumptions on elemental mobility. The main 
challenge for these calculations is determining consistent and representative trace element compositions for the listvenite series and for the model protoliths.

The listvenite series are characterized by strong downhole variations in mineralogy and geochemistry from the sample to the meter scale. For simplicity, mass balance calculations (Supplementary Text S2) were carried out for listvenites (including fuchsite-bearing listvenites) and for variously carbonated serpentinites, both averaged at the scale of the listvenite domains (Supplementary Table S3). The results are illustrated as isocon diagrams (Fig. 6) where averaged elemental concentrations of the altered rock are plotted against those of the model protolith. Immobile elements were identified on the basis of the largest number of elements which are consistent with a single isocon (line of immobility) to within their uncertainty in the protolith and altered rock (i.e. collinear on the plot). The 1:1 reference line on isocon diagrams corresponds to zero mass change during alteration. Isocons which lie above or below the 1:1 line indicate, respectively, overall mass loss or mass gain during alteration (reflecting overall concentration or dilution of immobile elements for each of these scenarios). Elements plotting above and below the isocon are enriched and depleted, respectively, in the altered rock compared to the model protolith.

The compositions of the model protoliths were determined on the basis of the published geochemical studies of the Semail peridotites for which structural (localization, distance to the Moho and/or to the sole) and petrological (lithology, mineralogy) information were available. They were calculated including the volatile compositions of the variously serpentinized Semail peridotites. We defined two endmember protolith compositions (Supplementary Table S3): (1) a refractory protolith, modelled using the compositions of MMS harzburgites and dunites [Gerbert-Gaillard, 2002; Godard et al., 2000; Hanghoj et al., 2010; Lippard et al., 1986] due to the lack of data on the composition of basal harzburgites and dunites; (2) a fertile protolith, calculated using the compositions of basal lherzolites, including amphibole-bearing samples [Khedr et al., 2014; Lippard et al., 1986; Takazawa et al., 2003]. The model refractory and fertile protoliths are noted MMS and basal lherzolite respectively in Fig. 6. For some trace elements, the published chemical database is limited (e.g., Ga) and/or highly variable (e.g., LREE, Cs) resulting in a large uncertainty in their distribution in the model protoliths, in particular for basal lherzolites; however, these elements represent a minor subset of the chemical database and therefore had little impact on the evaluation of the overall mass changes resulting from $\mathrm{CO}_{2}$ metasomatism.

The mass balance calculations comparing the composition of listvenites and serpentinites to the refractory protolith show co-linearity (within uncertainty) on the isocon diagrams for most major and trace elements (Fig. 6, Supplementary Text S2). Only listvenites II display inconsistent results with two parallel collinear slopes (Fig. 6c). The same calculations using the fertile model protolith for Listvenite II show collinear trends and elemental variations similar to those obtained for the adjoining domains (Fig. 6d). This result supports the hypothesis that the listvenite series are replacements of a mantle section analogous to the Banded Unit, with Listvenite domains I and III being formed after a harzburgitic/dunitic protolith, and Listvenite domain II after a (amphibole bearing) lherzolitic protolith.

In each domain, most chemical elements are aligned on the same collinear trend, from $\mathrm{SiO}_{2}, \mathrm{MgO}$ and $\mathrm{FeO}_{\mathrm{T}}$, the main constituents of the mantle protolith(s) of the listenite series, to $\mathrm{Al}_{2} \mathrm{O}_{3}, \mathrm{Na}_{2} \mathrm{O}$, and the transition elements generally concentrated in mantle peridotites $(\mathrm{V}, \mathrm{Cr}, \mathrm{Co}$, $\mathrm{Ni}, \mathrm{Mn}, \mathrm{Ti}$, and $\mathrm{Sc}$ ) and moderately incompatible lithophile trace elements such as HREE, 
MREE, Y, Zr and Hf. These results indicate that these elements are immobile at the scale of the listvenite domains despite their meter-scale scattered downhole distribution. It should be noted however that the most incompatible elements, even those generally considered as fluid immobile, display minor differences from one rock type and domain to the other (e.g., depleted LREE in Serpentinite I). In particular, $\mathrm{Nb}$, Ta and Th are systematically depleted relative to the model mantle protoliths. This could reveal trace element depleted protoliths compared to the models, but we posit that it most likely relates to the uncertainty due to the limited dataset on the composition of these elements in the Semail peridotites. The same consideration could explain the apparent systematic loss of Ga observed for all calculations.

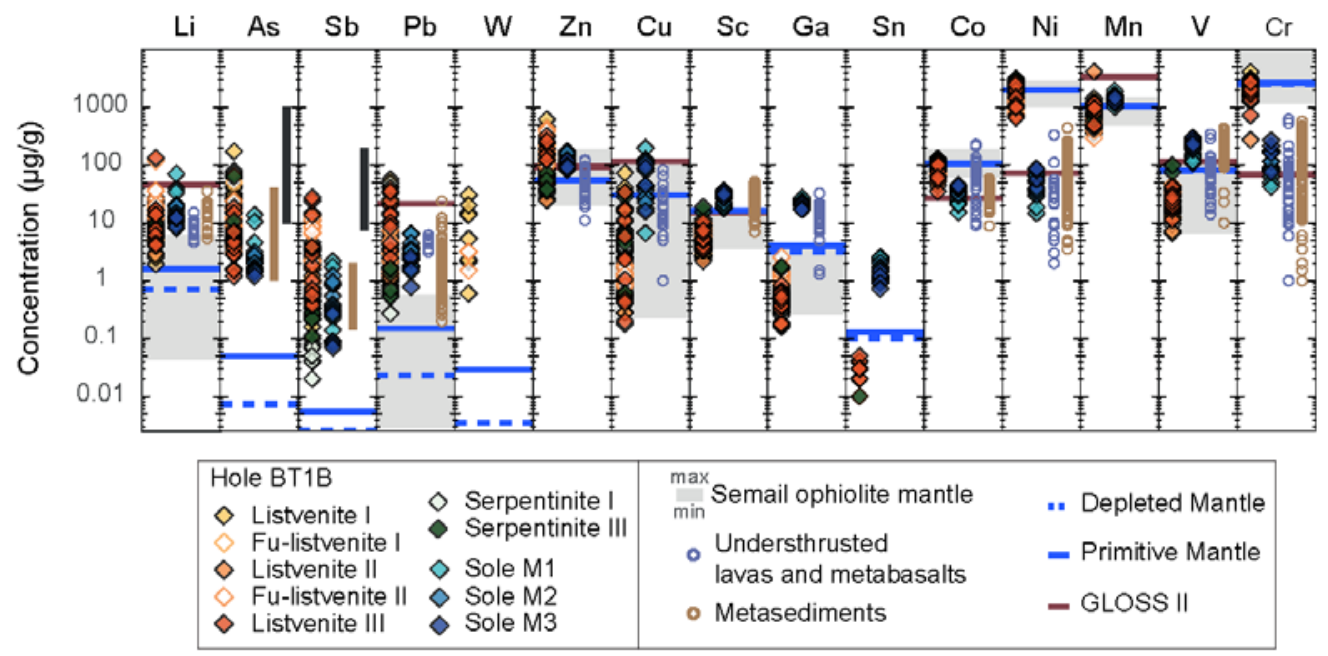

Figure 7. Caltech diagram of the composition of elemental abundance of BT1B listvenites series and metamorphic sole samples. Compositions are plotted on a log scale and compared with the compositional range of the Semail ophiolite peridotites (grey field) and lavas and sediments from the metamorphic sole and the understhrusted Hawasina assemblages (references in caption of Figure 4), and with PM [McDonough and Sun, 1995], DM [Salters and Stracke, 2004] and GLOSS II [Plank, 2014] values, Arsenic and antimony compositions are compared to the composition of abyssal plain sediments (brown line, [Plank and Ludden, 1992]) and hydrothermal sulfides (black line, [Fouquet et al., 2010]). Symbols are in legend.

A limited number of elements show significant changes in compositions relative to the model protoliths. Enrichments in $\mathrm{CO}_{2}$ are ubiquitous in agreement with BT1B listvenitization being driven by $\mathrm{CO}_{2}$ metasomatism as previously suggested by Falk and Kelemen [2015] for the Wadi Mansah listvenites. $\mathrm{CO}_{2}$ enrichments are associated with the development of two reaction pathways for carbonation: on one hand, the formation of variously carbonated serpentinites (Serpentinites I and III, Figs. 6b, f) and, on the other hand, that of listvenites (Listvenites I, II and III, Figs. 6a, d, e). Listvenites are distinguished from carbonated serpentinites by their depletion in $\mathrm{H}_{2} \mathrm{O}$, suggesting that $\mathrm{CO}_{2}$ addition induced the release of $\mathrm{H}_{2} \mathrm{O}$. This process could represent a non-negligible dehydration mechanism for serpentinized peridotites. It has been documented in several listvenite bodies from different geodynamic settings (e.g., Atlin listvenites [Hansen et al., 2005]).

Enrichments in $\mathrm{CaO}$ (where dolomite is present) and in most elements typically considered as fluid mobile, such as $\mathrm{Li}, \mathrm{K}, \mathrm{Rb}, \mathrm{Cs}, \mathrm{Ba}, \mathrm{Sr}, \mathrm{Pb}$ and $\mathrm{U}$, relative to model peridotite protoliths are also observed (Fig.6). These enrichments vary from one domain and rock type to the other thus suggesting downhole variability in fluid-rock interactions (see Section 5.2). 
Mass balance calculations indicate a significant increase of the mass of the listvenite series compared to their partially serpentinized model protoliths. The estimated mass increase was slightly less in carbonated serpentinites (12 to $31 \%$ ) than in listvenites (29 to 51 \%) (Fig. 6; Supplementary Table S4). The density of carbonated serpentinites and listvenites $(2.52 \pm 0.05$ g.cm ${ }^{-3}$ and $2.86 \pm 0.07$ g.cm ${ }^{-3}$ respectively [Kelemen et al., 2020]) being relatively close to that of the variously serpentinized Semail peridotites $\left(2.81 \pm 0.50 \mathrm{~g} . \mathrm{cm}^{-3}\right.$ [Dewandel, 2002]), volume expansion is of the same order of magnitude as mass changes (Supplementary Table S4). The abundant fractures and veining characterizing the listvenite series [Kelemen et al., 2020; Menzel et al., 2020b] possibly accommodated these mass and volume changes at the scale of the BT1B cored section. However these results raise the question of the mechanisms that facilitate such a large and heterogeneous increase in mass and volume at the scale of the Wadi Mansah massif.

5.2 The BT1B listvenite series: sampling the final stage of a protracted sequence of fluid rock interactions

BT1B listvenite series formed at low temperatures (between 245 to $45^{\circ} \mathrm{C}$ ) and shallow depths (from 10 to $2 \mathrm{~km}$ ) according to the study of Beinlich et al [2020] (clumped isotope thermometry coupled to oxygen isotopes), in agreement with previous results on the Wadi Mansah listvenites [Falk and Kelemen, 2015]. The fluids triggering listvenitization were particularly rich in $\mathrm{CO}_{2}$, possibly close to saturation, according to recent thermodynamic modelling [Kelemen et al., 2021]. The associated fluid-rock interactions resulted in strong mineralogical and compositional variability from the centimeter to the tens of meter-scale along the cored listvenites series (Fig. 3). Geochemistry shows also a sharp geochemical transition to the presently underlying metamorphic sole (with the exception of the $\mathrm{Ca}$ and $\mathrm{Sr}$ downhole trends) (Fig 2). These jagged chemical distributions indicate localized fluid-rock interactions and limited elemental transport across the basal thrust. This implies that the $\mathrm{CO}_{2}$-rich fluid(s) triggering the formation of the listvenites series did not originate directly from the metamorphic sole recovered at Hole BT1B. The main flow paths for these fluids were probably (sub-)parallel to the basal thrust. They followed the same direction as the fluids driving the earlier metasomatic events affecting the basal ophiolitic mantle and its metamorphic sole, and possibly reused the same pathways.

The BT1B listvenites series are systematically enriched in FME relative to the Semail ophiolite main mantle section, particularly in Cs, Rb, Ba and K (Fig. 6). Alkali-rich compositions are commonly observed along the ophiolite basal thrust in the metamorphic sole (e.g., [Ambrose et al., 2021; Ghent and Stout, 1981; Ishikawa et al., 2005]) and in the adjacent Banded Unit peridotites, in particular in the amphibole-rich lherzolites (e.g., [Khedr et al., 2013; Khedr et al., 2014; Prigent et al., 2018a; Yoshikawa et al., 2015]). These enrichments are typically interpreted as resulting from interactions with alkali-rich aqueous fluids, originating from the devolatilization of a slab (altered oceanic crust, sediments) at depth (granulite-amphibolite facies); fluid-rock interactions are however thought to occur at different pressure and temperature condition for the metamorphic sole and the Banded Unit peridotites. The extensive serpentinization characterizing the latter is also interpreted as resulting from interactions with slab-derived aqueous fluids thus suggesting that the basal thrust acted as an efficient fluid pathway also during the later stages of cooling of the ophiolite [Lippard et al., 1986; Prigent et al., 2018b]. Petrographic observations indicate that the BT1B listvenite series were formed after serpentinized peridotites [Beinlich et al., 2020; Kelemen et al., 2020] and our geochemical study shows that, when averaged at the meter to tens of meter scale, they preserved a peridotite 
composition for most major and trace elements in spite of their strong variability (Figs. 4, 7). We propose that the BT1B listvenite series replaced a section of serpentinized Banded Unit peridotites analogous in mineralogy and composition to those exposed elsewhere along the Semail mantle section (e.g., [Prigent et al., 2018a]). The previous metasomatic events forming the Banded Unit peridotites may have thus contributed to the alkali-rich signature of BT1B listvenite series.

The composition and mineralogy of the three geochemical domains identified for BT1B listvenite series relate primarily to the composition of their protoliths. Compared to Listvenite domains I and III, Listvenite domain II has average compositions comparable to that of the basal amphibole-bearing lherzolites, even for alkali elements $\mathrm{K}, \mathrm{Ba}, \mathrm{Cs}$ and $\mathrm{Rb}$. These enrichments are particularly prominent in the fuchsite-bearing listvenites. We posit that fuchsite is dominantly localized in Listvenite domain II because the concentrations in the chemical components allowing their formation (in particular, $\mathrm{Al}, \mathrm{K}$ ) were present mainly in the amphibole-rich lherzolites. Listvenite domain II is also distinguished by relatively low $\mathrm{Fe}^{3+} / \mathrm{Fe}_{\mathrm{T}}$, overlapping Semail ophiolite mantle values. These variable $\mathrm{Fe}^{3+} / \mathrm{Fe}_{\mathrm{T}}$ could reveal variable redox conditions due to the development of different reaction paths depending on the protolith compositions (e.g., buffering of local $\mathrm{fO}_{2}$ by Fe trapping in the fuchsite structure). They could also simply reflect changes in redox conditions during the serpentinization of the Banded Unit peridotites, previous to $\mathrm{CO}_{2}$ metasomatism. Detailed investigations of the distribution of iron and iron speciation between minerals and along the core would allow unraveling the contributions of these different processes. Finally, although a contribution of the protoliths to the FME budget of the BT1B listvenite series is probable, it is not sufficient to explain their high concentrations in these elements as illustrated on Figure 6. This suggests that the $\mathrm{CO}_{2}$-rich fluids triggering listvenitization contained non-negligible concentrations in FME, including in alkali elements, similar to the slab-derived fluids driving the high temperature metasomatism and serpentinization in the Banded Unit peridotites.

The Wadi Mansah listvenite series are characterized by the occurrence of variously carbonated serpentinite intervals crosscutting listvenites: BT1B core descriptions show that serpentinite-to-listenite transitions do not correspond to faults and our study shows that they have the same protoliths within a same geochemical domain (Figs. 4, 6, 7). This suggests that these changes in mineralogy reveal variable extents of reactions with $\mathrm{CO}_{2}$-rich fluids. Beinlich et al [2020] proposed that the variously carbonated serpentinites represented the least reacted intervals that preserved the incipient stages of carbonation of its serpentinized protolith. However, the development of dolomite-dominated $\mathrm{Ca}$ and Sr rich intervals in Listvenite Domains I and III reveal a possibly more complex process. The Ca-Sr rich intervals are located within, and at, the (talc-bearing) transition from serpentinites and listvenites, in the upper part of Listvenite Domains I (48 to $53 \mathrm{mbg}$ and 63 to $67 \mathrm{mbg}$ ) and throughout Listvenite Domain III, with Ca-Sr enrichments increasing toward the basal thrust. This downhole trend continues into the M1 metabasalts, drawing a shape similar to a diffusive front across the basal thrust (Fig. 2). Ca-Sr rich intervals also show increasing $\mathrm{Fe}^{3+} / \mathrm{Fe}_{\mathrm{T}}$ values, in particular towards the basal thrust. They are systematically associated to enrichments in redox sensitive $U$ suggesting fluid-rock interactions in an oxidized environment (e.g., [Paulick et al., 2006; Peters et al., 2017]). The listvenite series thus record interactions with Ca-depleted $\mathrm{CO}_{2}$-rich fluids and with $\mathrm{Ca}-\mathrm{Sr}-\mathrm{CO}_{2}$ rich oxidizing fluids. De Obeso et al. [2021] show that Sr derived from the de-volatilization at depth of Hawasina type carbonate/silicate sedimentary assemblages. Whether the interactions with Ca-depleted and -enriched $\mathrm{CO}_{2}$-rich fluids were contemporaneous or not, is difficult to 
estimate in a context where flow paths are highly channelized. Because (i) dolomite-rich zones are highly localized and appear to imprint listvenites (late dolomite veins, ...), and (ii) they predominate in the serpentinite intervals that were initially little affected by $\mathrm{CO}_{2}$ metasomatism, we speculate that the ingress of $\mathrm{Ca}-\mathrm{Sr}-\mathrm{CO}_{2}$-rich fluids followed the onset of the formation of the listvenite series.

Selective enrichments in FME, such as Li, Pb, Sb and As or U (Figs. 2, 3 and 7) are also observed, sometimes in association with slight changes in $\mathrm{Zn}$ and $\mathrm{Cu}$ compositions or in $\mathrm{Fe}^{3+} / \mathrm{Fe}_{\mathrm{T}}$. The most prominent occurs at $18-35 \mathrm{mbg}$ in the Listvenite domain $\mathrm{I}$, and shows enrichments in $\mathrm{Li}, \mathrm{Mn}, \mathrm{U}, \mathrm{Zn}$ and $\mathrm{Cu}$, and high $\mathrm{Fe}^{3+} / \mathrm{Fe}_{\mathrm{T}}$. These variations are not correlated to major changes in mineralogy or to geochemical domains, but they are observed in areas recording extensive fracturing and late re-cementation events, with locally the late precipitation of iron oxides (mostly hematite) [Menzel et al., 2020b]. Efficient fracturing may have favored effective and long-lasting fluid-rock interactions and elemental redistributions, possibly until the final stages of listvenitization.

Geochemistry allows to identify the respective roles of the composition of the protoliths and of the reacting fluids on the development of distinct reactions paths along the BT1B listenite series, however determining the timing of these processes in the context of the emplacement of the Semail ophiolite remains challenging. For instance, there is an overlap in the range of temperature conditions anticipated for the serpentinization of the Banded Unit by slab derived fluids $\left(<350^{\circ} \mathrm{C}\right.$, [Prigent et al., 2018b]) and for $\mathrm{CO}_{2}$ metasomatism along BT1B listvenite series [Beinlich et al., 2020], therefore it is possible that serpentinization and the onset of $\mathrm{CO}_{2}$ metasomatism were contemporaneous. Also, we cannot preclude a possible contribution of the water released by the formation of listvenites to the serpentinization of neighboring peridotites, and the timing and context of the changes in the composition of reacting fluids are unclear. Further investigations coupling petro-structural and fine scale geochemical and isotopic investigations would allow to better constrain the hydrodynamic and chemical processes controlling this protracted sequence of fluid-rock interactions and their relationships to deformation and the local tectonic environment.

\subsection{Contribution of listvenites to global chemical budgets}

The BT1B listvenites are characterized by a dual geochemical signature: they preserve the composition(s) of their serpentinized protolith(s) for major elements (except for Ca) and most compatible (e.g., V, Sc, Ni, Cr, Co) and incompatible lithophile elements (e.g., REE, HFSE) (Fig. 6) but they record significant enrichments in most of the trace elements and metals considered as fluid mobile ( $\mathrm{Li}, \mathrm{K}, \mathrm{Cs}, \mathrm{Rb}, \mathrm{K}, \mathrm{Ba}, \mathrm{Sr}$, As, Sb, and W, Fig. 4, 6, 7). They commonly have FME abundances similar, or even enriched, compared to the Semail ophiolite neighboring lithologies (sole, metabasalts and metasediments) and comparable to subduction related serpentinites (e.g., [Deschamps et al., 2013; Peters et al., 2017]) and ophicarbonates [Cannao et al., 2020] for alkali elements. The variously carbonated BT1B serpentinites display similar enrichments but with slightly more prominent $U$ anomalies and, selective enrichments in $\mathrm{Ca}$ and Sr, and in LREE, a trend typical of carbonated oceanic serpentinites and ophicarbonates (e.g., [Cannao et al., 2020; Noel et al., 2018; Peters et al., 2017]). All the listvenite series show significant remobilization ( $\mathrm{Zn}, \mathrm{Cu}$ ) and enrichments (As, Sb, $\mathrm{Pb}$ ) of chalcophile elements and of selected siderophile elements (variable $\mathrm{Ni}$, Co and $\mathrm{Cr}$, and enrichments in $\mathrm{W}$ ), a common characteristics of listvenites that typically show ore-grade compositions for these elements (e.g., 
[Belogub et al., 2017; Buisson and Leblanc, 1985; Escayola et al., 2009; Halls and Zhao, 1995; Laznicka, 2010]); such variations are also characteristic of highly serpentinized ultramafic basements hosting high temperature oceanic hydrothermal vents and sulfide deposits (e.g., [Andreani et al., 2014]). The redistribution of metals and FME in variously carbonated and/or serpentinized peridotites is classically interpreted in the context of their geodynamic environment, but the meter-scale chemical variability of the BT1B listvenite series suggests a key role of local and transient reactive processes associated to the ingress of $\mathrm{CO}_{2}$-rich fluids. Laboratory experiments show that the interplay between carbonation (and/or serpentinization) kinetics, solute transport and fluid renewal at the mineral interface influences effective reaction pathways that, in turn, modify local chemical conditions (and reaction kinetics) by changing the mineralogy of reacted samples and fluid composition (e.g., [Andreani et al., 2009; Godard et al., 2013; Grozeva et al., 2017; Janecky and Seyfried, 1986; Peuble et al., 2019; Peuble et al., 2015; Seyfried et al., 2007]). Similar reactive transport mechanisms could have caused the jagged elemental redistribution along BT1B listvenite series and possibly contributed to their dual geochemical signature. Disequilibrium textures indicative of fast growth of magnesite are common [Beinlich et al., 2020]: this suggests that reaction kinetics were fast compared to solute transport whatever the fluid composition. They are associated with the development of nanoporosity, that could have efficiently trap FME as fluid or solid phases (e.g., [Cannaò and Malaspina, 2018]). Similarly, in the absence of silica addition at the scale of the core (Fig. 6), quartz-forming silicification reactions likely relate to the incomplete removal of silica during coupled silicate dissolution - carbonate precipitation reactions, as commonly observed in reactive percolation experiments when carbonation kinetics are fast [Peuble et al., 2019; Peuble et al., 2015].

Further studies are needed to test this model of elemental redistribution for listvenites formed by $\mathrm{CO}_{2}$ metasomatism, however it is worth to note that it accounts for some of the prominent characteristics of the BT1B listvenite series. First, fast carbonation kinetics are expected to induce reaction-driven fracturing (e.g., [Jamtveit et al., 2008; Lambart et al., 2018; Ulven et al., 2014]). This mechanism may have contributed to the development of the high density veining network in BT1B listvenite series, and thus helped to accommodate the large spatially heterogeneous large increase in volume associated with their formation. Second, the efficient trapping of fluid mobile trace elements combined with the preservation of the protolith mantle composition for all other trace elements produced extreme fractionation of FME relative to immobile incompatible elements (e.g., Th or, to a certain extent, Ce, Fig. 8). This fractionation is particularly high for alkali elements $(\mathrm{Li}, \mathrm{Ba}, \mathrm{Cs}, \mathrm{Rb})$ and chalcophile elements $(\mathrm{Pb})$ with $\mathrm{Li} / \mathrm{Th}$ of $2000-10^{5}, \mathrm{Ba} / \mathrm{Th}$ of $500-10^{6}, \mathrm{Cs} / \mathrm{Th}$ of $100-5000$ and $\mathrm{Pb} / \mathrm{Ce}$ up to $5 \times 10^{5}$. Relative enrichments in $\mathrm{U}$ are comparatively less prominent (e.g., U/Th 1-100). These values are significantly higher than that of the possible sources of fluids (e.g. $\mathrm{Li} / \mathrm{Th}<30, \mathrm{Ba} / \mathrm{Th}<200$, $\mathrm{Cs} / \mathrm{Th}<20, \mathrm{U} / \mathrm{Th}<0.5$, and $\mathrm{Pb} / \mathrm{Ce}<0.5$ in metamorphic sole (this study) and sediments (GLOSS II [Plank, 2014]). These elemental fractionations follow trends similar to what is observed for forearc serpentinites when compared to oceanic serpentinites [Peters et al., 2017] but the degree of fractionation measured in the BT1B listvenite series is significantly higher. If significant amounts of listvenites were recycled, such extreme compositions could affect that of the subduction-related volcanics (e.g., by inducing a prominent alkali-rich sedimentary signature) or, over longer time scales, the mantle isotopic signature, for instance for lead isotopes due to their high $\mathrm{Pb}$ concentrations compared to $\mathrm{U}$ and $\mathrm{Th}$ (e.g., $\mathrm{U} / \mathrm{Pb}<0.005$ ). They could contribute to the development of a high $\mathrm{Pb} / \mathrm{Ce}$, low $\mathrm{Th} / \mathrm{Pb}$ and $\mathrm{U} / \mathrm{Pb}$ reservoir and, hence, offer a potential solution to the "first lead 
paradox" [Hofmann, 2008]. Recent studies have shown the role of carbonation of oceanic and subduction-related peridotites in the global carbon cycle (e.g., [Cannaò et al., 2020; Kelemen and Manning, 2015]). Our results suggest that, similar to what proposed for (de-)serpentinization reactions (e.g., [Deschamps et al., 2013; Spandler and Pirard, 2013]), carbonation reactions could also impact the redistribution of fluid mobile elements and metals and play a role in their global geochemical cycles.
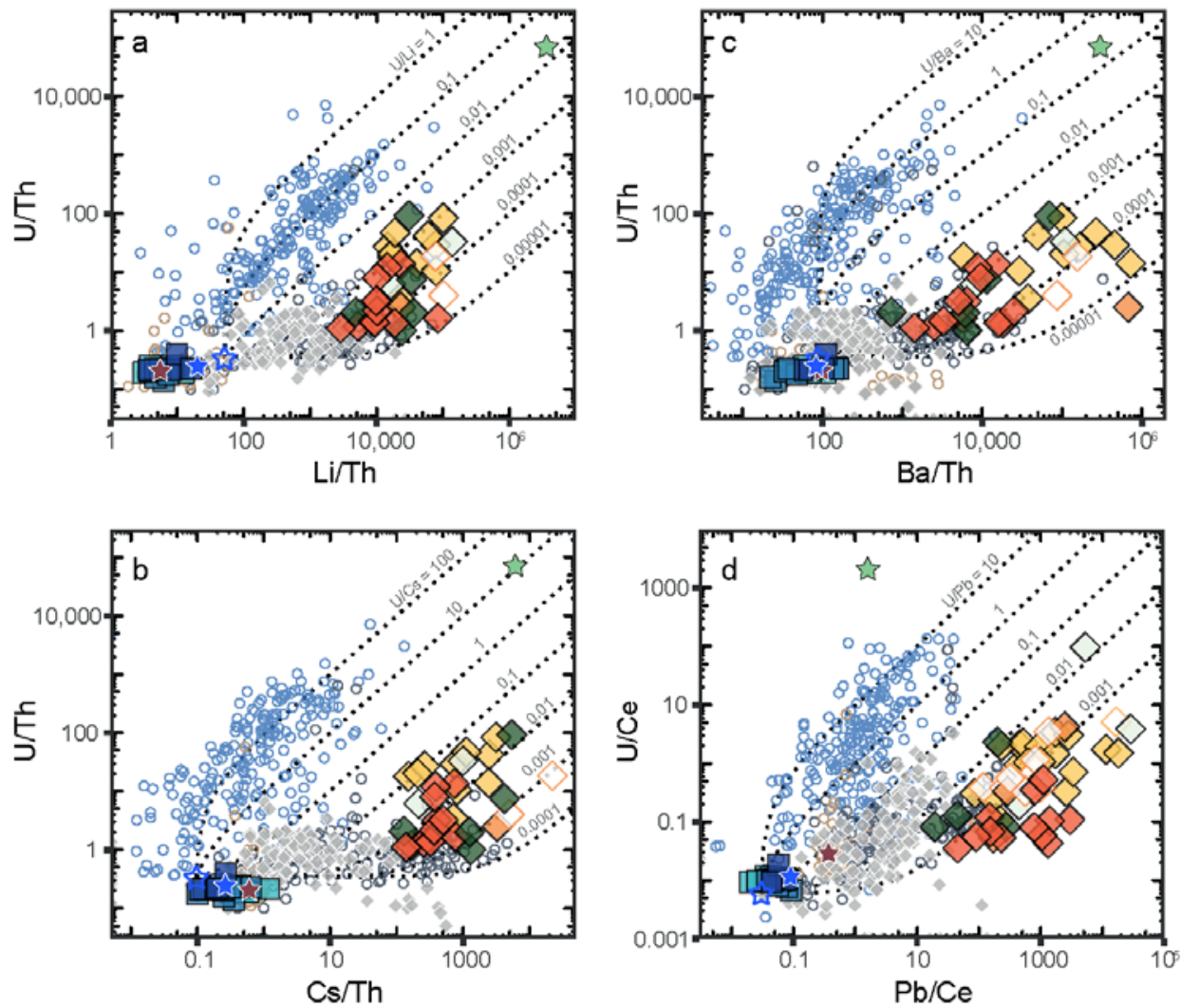

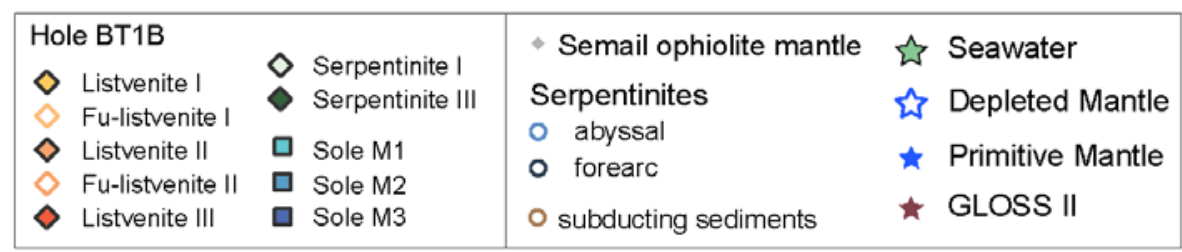

Figure 8. Scatterplots showing fluid mobile element enrichment relative to immobile trace elements in BT1B listvenites and serpentinites (a) U/Th versus Li/Th. (b) U/Th versus Cs/Th. (c) U/Th versus Ba/Th. (d) $\mathrm{U} / \mathrm{Ce}$ versus $\mathrm{Pb} / \mathrm{Ce}$. Plotted for comparison are: compiled serpentinite compositions from abyssal (blue circles) and forearc (dark blue circles) settings (data from compilations in Peters et al. [2017] and Deschamps et al. [2013]); compiled Semail ophiolite peridotite data; subducting sediments [Plank et al., 2007]; PM [McDonough and Sun, 1995], DM [Salters and Stracke, 2004], GLOSS-II [Plank, 2014] and seawater [Li, 1991] values. Also plotted are lines of addition of fluid mobile elements in various ratios at fixed Th or Ce. Literature data sources for Semail ophiolite are as in previous plots. Symbols are in legend. 


\section{Conclusions}

During ICDP Oman Drilling Project, the transition from the base of the Semail ophiolite to the underlying metamorphic sole was drilled at Hole BT1B (Wadi Mansah). We analyzed the bulk major, volatile and trace element compositions of 65 variously carbonated serpentinites and (fuchsite-bearing) listvenites, and 19 metamorphic rocks collected from recovered cores, with the aim of better constraining chemical transfers associated with peridotite carbonation along the ophiolite basal thrust.

The listvenite series record the formation of listvenites replacing a serpentinized peridotite protolith: this process is marked by $\mathrm{CO}_{2}$ addition and $\mathrm{H}_{2} \mathrm{O}$ removal. Their bulk geochemistry is highly variable at the meter scale yet, on average, it is close to that of the refractory peridotites of the Semail mantle section for most major and lithophile trace elements, except of the fuchsite-bearing listvenite domain that has compositions overlapping that of the more fertile, often amphibole-bearing, basal lherzolites. Thus, the type of precursor peridotite can be well recognized in spite of extensive peridotite carbonation. All samples are enriched in fluid mobile elements compared to the composition of the Semail peridotites (up to $\sim 10^{3}-10^{4} \mathrm{x}$ PM). They have concentrations similar to the metamorphic sole and/or associated metasediments for elements such as Cs, $\mathrm{Sr}$ and $\mathrm{Ca}$ and sometimes even higher for elements such as $\mathrm{Pb}, \mathrm{Li}, \mathrm{As}$, and $\mathrm{Sb}$. Enrichments in $\mathrm{Ca}$ and $\mathrm{Sr}$ are decoupled from those in other FME, indicating interactions with several batches of $\mathrm{CO}_{2}$-rich fluids originating in neighboring lithologies or deeper along the basal thrust. These results suggest that interactions with $\mathrm{CO}_{2}$-rich fluids can induce extreme elemental fractionation and enrichments in carbonated peridotites. These processes could represent a major mechanism (re)mobilizing FME and volatile elements along convergent margins. 


\section{Acknowledgments, Samples, and Data}

This work benefited from fruitful discussions with Francoise Boudier, Cécile Prigent, Manuel Menzel and Emilien Oliot. We thank Céline Martin and Léa Causse for their assistance for trace element analyses at the Géosciences Montpellier clean lab facility and on the AETEISO platform ("Analyses des Eléments en Trace dans l'Environnement et ISOtopes"; OREME observatory, University of Montpellier). We would like to thank also the associate editor, , Phil Janney, as well as L. W. Diamond and an anonymous reviewer for their comments and suggestions on the manuscript.

This research used samples and/or data provided by the Oman Drilling Project. The Oman Drilling Project (OmanDP) has been possible through co-mingled funds from the International Continental Scientific Drilling Project (ICDP; Kelemen, Matter, Teagle Lead PIs), the Sloan Foundation - Deep Carbon Observatory (Grant 2014-3-01, Kelemen PI), the National Science Foundation (NSF-EAR-1516300, Kelemen lead PI), NASA - Astrobiology Institute (NNA15BB02A, Templeton PI), the German Research Foundation (DFG: KO 1723/21-1, Koepke PI), the Japanese Society for the Promotion of Science (JSPS no:16H06347, Michibayashi PI; and KAKENHI 16H02742, Takazawa PI), the European Research Council (Adv: no.669972; Jamveit PI), the Swiss National Science Foundation (SNF:20FI21_163073, Früh-Green PI), JAMSTEC, the TAMU-JR Science Operator, and contributions from the Sultanate of Oman Ministry of Regional Municipalities and Water Resources, the Oman Public Authority of Mining, Sultan Qaboos University, CNRS-Univ. Montpellier, Columbia University of New York, and the University of Southampton.

This study was funded by Project ANR-18-CE01-0014-01 LISZT.

The dataset is available on the PANGAEA data archiving platform (https://doi.pangaea.de/10.1594/PANGAEA.937490). 


\section{References}

Ambrose, T. K., D. J. Waters, M. P. Searle, P. Gopon, and J. B. Forshaw (2021), Burial, Accretion, and Exhumation of the Metamorphic Sole of the Oman-UAE Ophiolite, Tectonics, 40(4), e2020TC006392, doi:https://doi.org/10.1029/2020TC006392.

Andreani, M., J. Escartin, A. Delacour, B. Ildefonse, M. Godard, J. Dyment, A. E. Fallick, and Y. Fouquet (2014), Tectonic structure, lithology and hydrothermal signature of the Rainbow massif (Mid-Atlantic Ridge $36^{\circ} 14^{\prime} \mathrm{N}$ ), Geochemistry, Geophysics, Geosystems, 15(9), 3543-3571, DOI: 3510.1002/2014GC005269.

Andreani, M., L. Luquot, P. Gouze, M. Godard, E. Hoise, and B. Gibert (2009), Experimental study of carbon sequestration reactions controlled by the percolation of $\mathrm{CO}_{2}$-rich brine through peridotites, Environ. Sci. Technol., 43(4), 1226-1231; DOI: 1210.1021/es8018429.

Azer, M. K., H. A. Gahlan, P. D. Asimow, H. S. Mubarak, and K. M. Al-Kahtany (2019), Multiple Stages of Carbonation and Element Redistribution during Formation of Ultramafic-Hosted Magnesite in Neoproterozoic Ophiolites of the Arabian-Nubian Shield, Egypt, The Journal of Geology, 127(1), 81-107, doi:10.1086/700652.

Baumgartner, L. P., and S. N. Olsen (1995), A least-squares approach to mass transport calculations using the isocon method, Economic Geology, 90(5), 1261-1270, doi:10.2113/gsecongeo.90.5.1261.

Bechennec, F., J. Le Metour, D. Rabu, C. Bourdillon-de-Grissac, P. de Wever, M. Beurrier, and M. Villey (1990), The Hawasina Nappes: stratigraphy, palaeogeography and structural evolution of a fragment of the south-Tethyan passive continental margin, Geological Society, London, Special Publications, 49(1), 213-223, doi:10.1144/gsl.sp.1992.049.01.14.

Beinlich, A., O. Plümper, E. Boter, I. A. Müller, F. Kourim, M. Ziegler, Y. Harigane, R. Lafay, P. B. Kelemen, and the Oman Drilling Project Science Team (2020), Ultramafic Rock Carbonation: Constraints From Listvenite Core BT1B, Oman Drilling Project, Journal of Geophysical Research: Solid Earth, 125(6), e2019JB019060, doi:https://doi.org/10.1029/2019JB019060.

Belgrano, T. M., L. W. Diamond, Y. Vogt, A. R. Biedermann, S. A. Gilgen, and K. Al-Tobi (2019), A revised map of volcanic units in the Oman ophiolite: insights intothe architecture of an oceanic proto-arc volcanic sequence, Solid Earth, 10, 1181-1217, doi: 1110.5194/se-1110-1181-2019.

Belogub, E. V., I. Y. Melekestseva, K. A. Novoselov, M. V. Zabotina, G. A. Tret'yakov, V. V. Zaykov, and A. M. Yuminov (2017), Listvenite-related gold deposits of the South Urals (Russia): A review, Ore Geology Reviews, 85, 247-270, doi:https://doi.org/10.1016/j.oregeorev.2016.11.008.

Boschi, C., A. Dini, L. Dallai, G. Ruggieri, and G. Gianelli (2009), Enhanced CO2-mineral sequestration by cyclic hydraulic fracturing and Si-rich fluid infiltration into serpentinites at Malentrata (Tuscany, Italy), Chemical Geology, 265(1), 209-226, doi:https://doi.org/10.1016/j.chemgeo.2009.03.016.

Boskabadi, A., I. K. Pitcairn, M. I. Leybourne, D. A. H. Teagle, M. J. Cooper, H. Hadizadeh, R. Nasiri Bezenjani, and R. Monazzami Bagherzadeh (2020), Carbonation of ophiolitic ultramafic rocks: Listvenite formation in the Late Cretaceous ophiolites of eastern Iran, Lithos, 352-353, 105307, doi:https://doi.org/10.1016/j.lithos.2019.105307.

Boudier, F., A. Baronnet, and D. Mainprice (2010), Serpentine Mineral Replacements of Natural Olivine and their Seismic Implications: Oceanic Lizardite versus Subduction-Related Antigorite, Journal of Petrology, 51(1-2), 495512, doi:410.1093/petrology/egp1049, doi:10.1093/petrology/egp049.

Boudier, F., G. Ceuleneer, and A. Nicolas (1988), Shear zones, thrusts and related magmatism in the Oman Ophiolite; initiation of thrusting on an oceanic ridge, Tectonophysics, 151(1-4), 275-296.

Boudier, F., and R. G. Coleman (1981), Cross section through the peridotite in the Samail ophiolite, southeastern Oman mountains, J. Geophys. Res., 86, 2573-2592.

Boudier, F., and A. Nicolas (1988), Special Issue: The ophiolites of Oman, Tectonophysics, 151(1-4).

Boudier, F., and A. Nicolas (2018), Synchronous Seafloor Spreading and Subduction at the Paleo-Convergent Margin of Semail and Arabia, Tectonics, 37(9), 2961-2982, doi:https://doi.org/10.1029/2018TC005099.

Buisson, G., and M. Leblanc (1985), Gold in carbonatized ultramafic rocks from ophiolite complexes, Economic Geology, 80(7), 2028-2029, doi:10.2113/gsecongeo.80.7.2028.

Cannaò, E., and N. Malaspina (2018), From oceanic to continental subduction: Implications for the geochemical and redox evolution of the supra-subduction mantle, Geosphere, 14(6), 2311-2336, doi:10.1130/ges01597.1.

Cannao, E., M. Scambelluri, G. E. Bebout, S. Agostini, T. Pettke, M. Godard, and L. Crispini (2020), Ophicarbonate evolution from seafloor to subduction and implications for deep-Earth C cycling, Chem. Geol., 546, 119626; doi:119610.111016/j.chemgeo.112020.119626, doi:10.1016/j.chemgeo.2020.119626.

Cannaò, E., M. Tiepolo, G. E. Bebout, and M. Scambelluri (2020), Into the deep and beyond: Carbon and nitrogen subduction recycling in secondary peridotites, Earth and Planetary Science Letters, 543, 116328, doi:https://doi.org/10.1016/j.epsl.2020.116328. 
Chauvet, F., H. Lapierre, R. C. Maury, D. Bosch, C. Basile, J. Cotten, P. Brunet, and S. Campillo (2011), Triassic alkaline magmatism of the Hawasina Nappes: Post-breakup melting of the Oman lithospheric mantle modified by the Permian Neotethyan Plume, Lithos, 122(1), 122-136, doi:https://doi.org/10.1016/j.lithos.2010.12.006.

Coleman, R. G., and C. A. Hopson (1981), Oman ophiolite Special Issue, J. Geophys. Res., B86(4), 2497-2782.

De Obeso, J. C., P. Kelemen, J. M. Leong, C. Manning, M. Menzel, Y. Cai, M. Godard, and Oman Drilling Project Phase 1 Science Party (2021), Deep sourced fluids for peridotite carbonation in the shallow mantle wedge of a fossil subduction zone: Sr and C isotope profiles of OmanDP Hole BT1B, Earth and Space Science Open Archive, doi.org/10.1002/essoar.10507483.10507481.

Deer, W. A., R. A. Howie, and J. Zussman (1996), An Introduction to the Rock-Forming Minerals (2nd Edition), 712 pp., Prentice Hall.

Deschamps, F., M. Godard, S. Guillot, and K. Hattori (2013), Geochemistry of subduction zones serpentinites: A review, Lithos, 178("Serpentinites from mid-oceanic ridges to subduction", B. Reynard, M. Godard and S. Guillot, eds.), 96-127, doi:110.1016/j.lithos.2013.1005.1019.

Dewandel, B. (2002), Structure et fonctionnement hydrogéologique d'un aquifère discontinu : l'ophiolite d'Oman, Thèse de doctorat (Direction: F. Boudier) thesis, 328 p. pp, Montpellier 2, Montpellier.

Ernewein, M., C. Pflumio, and H. Whitechurch (1988), The death of an accretion zone as evidenced by the magmatic history of the Sumail ophiolite (Oman), Tectonophysics, 151(Spec. Issue - The ophiolites of Oman), 247274.

Escayola, M. P., J. A. Proenza, C. R. Van Staal, N. Rogers, and T. Skulski (2009), The Point Rousse listvenites, Baie Verte, Newfoundland: altered ultramafic rocks with potential for gold mineralization in Geol. Survey Report, 09-1, edited, pp. 1-12, Newfoundland and Labrador Dept Natural Resources.

Falk, E. S., and P. B. Kelemen (2015), Geochemistry and petrology of listvenite in the Samail ophiolite, Sultanate of Oman: Complete carbonation of peridotite during ophiolite emplacement, Geochimica et Cosmochimica Acta, 160, 70-90, doi:https://doi.org/10.1016/j.gca.2015.03.014.

Fouquet, Y., P. Cambon, J. Etoubleau, J. L. Charlou, H. OndréAs, F. J. A. S. Barriga, G. Cherkashov, T. Semkova, I. Poroshina, M. Bohn, J. P. Donval, K. Henry, P. Murphy, and O. Rouxel (2010), Geodiversity of Hydrothermal Processes Along the Mid-Atlantic Ridge and Ultramafic-Hosted Mineralization: a New Type Of Oceanic Cu-Zn-Co$\mathrm{Au}$ Volcanogenic Massive Sulfide Deposit, in Diversity Of Hydrothermal Systems On Slow Spreading Ocean Ridges, edited, pp. 321-367, doi:https://doi.org/10.1029/2008GM000746.

Gerbert-Gaillard, L. (2002), Caractérisation géochimique des peridotites de l'ophiolite d'Oman : Processus magmatiques aux limites lithosphere/asthenosphere, Thèse de doctorat, Co-direction F. Boudier et M. Godard thesis, 266 pp, Montpellier 2, Montpellier.

Ghent, E. D., and M. Z. Stout (1981), Metamorphism at the base of the Semail ophiolite, Southeastern Oman ophiolite, J. Geophys. Res., 86, 2557-2573.

Glennie, K. W., M. G. A. Boeuf, M. W. Hugues Clark, M. Moody-Stuart, W. F. H. Pilaar, and B. M. Reinhardt (1974), Geology of the Oman Mountains, 423 pp., Neder. Mijn. Geol. Genoot., Delft, Netherlands.

Godard, M., D. Bosch, and F. Einaudi (2006), A MORB source for low Ti magmatism in the Semail ophiolite, Chem. Geol., 234, 58-78.

Godard, M., J.-M. Dautria, and M. Perrin (2003), Geochemical variability of the Oman ophiolite lavas: Relationship with spatial distribution and paleomagnetic directions, Geochem. Geophys. Geosyst., 4(6), 8609, doi:8610.1029/2002GC000452.

Godard, M., D. Jousselin, and J.-L. Bodinier (2000), Relationships between geochemistry and structure beneath a palaeo-spreading centre: A study of the mantle section in the Oman Ophiolite, Earth Planet. Sci. Lett., 180, 133148.

Godard, M., L. Luquot, M. Andreani, and P. Gouze (2013), Incipient hydration of mantle lithosphere at ridges: A reactive-percolation experiment, Earth Planet. Sci. Lett., 371-372, 92-102, doi: 110.1016/j.epsl.2013.1003.1052.

Goodenough, K. M., M. T. Styles, D. Schofield, R. J. Thomas, Q. C. Crowley, R. M. Lilly, J. McKervey, D. Stephenson, and J. N. Carney (2010), Architecture of the Oman-UAE ophiolite: evidence for a multi-phase magmatic history, Arabian Journal of Geosciences, 3(4), 439-458, doi:10.1007/s12517-010-0177-3.

Grant, J. A. (1986), The isocon diagram; a simple solution to Gresens' equation for metasomatic alteration, Economic Geology, 81(8), 1976-1982, doi:10.2113/gsecongeo.81.8.1976.

Grozeva, N. G., F. Klein, J. S. Seewald, and S. P. Sylva (2017), Experimental study of carbonate formation in oceanic peridotite, Geochimica et Cosmochimica Acta, 199, 264-286, doi:https://doi.org/10.1016/j.gca.2016.10.052.

Halls, C., and R. Zhao (1995), Listvenite and related rocks: perspectives on terminology and mineralogy with reference to an occurrence at Cregganbaun, Co. Mayo, Republic of Ireland, Mineralium Deposita, 30(3), 303-313, doi:10.1007/BF00196366. 
Hanghoj, K., P. Kelemen, D. Hassler, and M. Godard (2010), Composition and genesis of depleted mantle peridotites from the Wadi Tayin massif, Oman ophiolite. Major and trace element geochemistry, and Os isotope and PGE systematics, J. Petrol., 51(1\&2), 201-227, doi:210.1093/petrology/egp1077.

Hansen, L. D., G. M. Dipple, T. M. Gordon, and D. A. Kellett (2005), Carbonated serpentinite (Listwanite) at Atlin, British Columbia: A geological analogue to Carbon Dioxide sequestration, The Canadian Mineralogist, 43(1), 225239, doi:10.2113/gscanmin.43.1.225.

Hofmann, A. W. (2008), The enduring lead paradox, Nature Geoscience, 1(12), 812-813, doi:10.1038/ngeo372.

Hopson, C. A., R. G. Coleman, R. T. Gregory, J. S. Pallister, and E. H. Bailey (1981), Geologic section through the Samail ophiolite and associated rocks along a Muscat-Ibra transect, southeastern Oman mountains, J. Geophys. Res., 86(Spc. Issue - Oman ophiolite), 2527-2544.

Ishikawa, T., S. Fujisawa, K. Nagaishi, and T. Masuda (2005), Trace element characteristics of the fluid liberated from amphibolite-facies slab: Inference from the metamorphic sole beneath the Oman ophiolite and implication for boninite genesis, Earth Planet. Sci. Lett., 240, 355-377.

Jamtveit, B., A. Malthe-Sørenssen, and O. Kostenko (2008), Reaction enhanced permeability during retrogressive metamorphism, Earth and Planetary Science Letters, 267(3), 620-627, doi:https://doi.org/10.1016/j.epsl.2007.12.016.

Janecky, D. R., and W. E. Seyfried (1986), Hydrothermal serpentinization of peridotite within the oceanic-crustExperimental investigations of mineralogy and major element chemistry, Geochimica et Cosmochimica Acta, 50(7), 1357-1378, doi:10.1016/0016-7037(86)90311-x.

Kelemen, P., J. C. de Obeso, J. M. Leong, M. Godard, A. J. Kotowski, C. Manning, E. T. Ellison, M. Menzel, J. L. Urai, J. G. Hirth, M. Rioux, D. Stöckli, R. Lafay, A. Beinlich, J. A. Coggon, N. H. Warsi, J. Matter, D. Teagle, K. Michibayashi, E. Takazawa, Z. Al Sulaimani, and Oman Drilling Project Science Team (2021), Mass transfer into the leading edge of the mantle wedge: Initial Results from Oman Drilling Project Hole BT1B, Earth and Space Science Open Archive, https://doi.org/10.1002/essoar.10507370.10507371.

Kelemen, P. B., and C. E. Manning (2015), Reevaluating carbon fluxes in subduction zones, what goes down, mostly comes up, Proceedings of the National Academy of Sciences, 112(30), E3997-E4006, doi:10.1073/pnas.1507889112.

Kelemen, P. B., J. Matter, E. E. Streit, J. F. Rudge, W. B. Curry, and J. Blusztajn (2011), Rates and Mechanisms of Mineral Carbonation in Peridotite: Natural Processes and Recipes for Enhanced, in situ CO2 Capture and Storage, in Annual Review of Earth and Planetary Sciences, Vol 39, edited by R. Jeanloz and K. H. Freeman, pp. 545-576, doi:10.1146/annurev-earth-092010-152509.

Kelemen, P. B., J. M. Matter, D. A. H. Teagle, J. A. Coggon, and the Oman Drilling Project Science Team (2020), Proceedings of the Oman Drilling Project, College Station, TX.

Khedr, M. Z., S. Arai, and M. Python (2013), Petrology and chemistry of basal lherzolites above the metamorphic sole from Wadi Sarami central Oman ophiolite, Journal of Mineralogical and Petrological Sciences, 108(1), 13-24, doi:10.2465/jmps.121026.

Khedr, M. Z., S. Arai, M. Python, and A. Tamura (2014), Chemical variations of abyssal peridotites in the central Oman ophiolite: Evidence of oceanic mantle heterogeneity, Gondwana Research, 25(3), 1242-1262, doi:https://doi.org/10.1016/j.gr.2013.05.010.

Lambart, S., H. M. Savage, B. G. Robinson, and P. B. Kelemen (2018), Experimental Investigation of the Pressure of Crystallization of $\mathrm{Ca}(\mathrm{OH}) 2$ : Implications for the Reactive Cracking Process, Geochemistry, Geophysics, Geosystems, 19(9), 3448-3458, doi:https://doi.org/10.1029/2018GC007609.

Lapierre, H., A. Samper, D. Bosch, R. C. Maury, F. Béchennec, J. Cotten, A. Demant, P. Brunet, F. Keller, and J. Marcoux (2004), The Tethyan plume: geochemical diversity of Middle Permian basalts from the Oman rifted margin, Lithos, 74(3), 167-198, doi:https://doi.org/10.1016/j.lithos.2004.02.006.

Laznicka, P. (2010), Giant Metallic Deposits: Future Sources of Industrial Metals, 949 pp., Springer.

Le Mée, L., J. Girardeau, and C. Monnier (2004), Mantle segmentation along the Oman ophiolite fossil mid-ocean ridge, Nature, 432, 167-172.

Li, Y.-H. (1991), Distribution patterns of the elements in the ocean: A synthesis, Geochimica et Cosmochimica Acta, 55(11), 3223-3240, doi:https://doi.org/10.1016/0016-7037(91)90485-N.

Linckens, J., M. Herwegh, and O. Müntener (2011), Linking temperature estimates and microstructures in deformed polymineralic mantle rocks, Geochemistry, Geophysics, Geosystems, 12(8), doi:https://doi.org/10.1029/2011GC003536.

Lippard, S. J., A. W. Shelton, and I. G. Gass (Eds.) (1986), The ophiolite of northern Oman, 178 pp., Backwell Scientific Publications, London. 
MacLeod, C. J., C. Johan Lissenberg, and L. E. Bibby (2013), "Moist MORB” axial magmatism in the Oman ophiolite: The evidence against a mid-ocean ridge origin, Geology, 41(4), 459-462, doi:10.1130/g33904.1.

Maury, R. C., F. Béchennec, J. Cotten, M. Caroff, F. Cordey, and J. Marcoux (2003), Middle Permian plume-related magmatism of the Hawasina Nappes and the Arabian Platform: Implications on the evolution of the Neotethyan margin in Oman, Tectonics, 22(6), 1073, doi:1010.1029/2002TC001483.

McDonough, W. F., and S. S. Sun (1995), The composition of the Earth, Chem. Geol., 120(3-4), 223-253.

Menzel, M. D., C. J. Garrido, and V. López Sánchez-Vizcaíno (2020a), Fluid-mediated carbon release from serpentinite-hosted carbonates during dehydration of antigorite-serpentinite in subduction zones, Earth and Planetary Science Letters, 531, 115964, doi:https://doi.org/10.1016/j.epsl.2019.115964.

Menzel, M. D., C. J. Garrido, V. López Sánchez-Vizcaíno, C. Marchesi, K. Hidas, M. P. Escayola, and A. Delgado Huertas (2018), Carbonation of mantle peridotite by CO2-rich fluids: the formation of listvenites in the Advocate ophiolite complex (Newfoundland, Canada), Lithos, 323, 238-261, doi:https://doi.org/10.1016/j.lithos.2018.06.001.

Menzel, M. D., J. L. Urai, J. C. de Obeso, A. Kotowski, C. E. Manning, P. B. Kelemen, M. Kettermann, A. P. Jesus, Y. Harigane, and t. O. D. P. P. S. Team (2020b), Brittle Deformation of Carbonated Peridotite-Insights From Listvenites of the Samail Ophiolite (Oman Drilling Project Hole BT1B), Journal of Geophysical Research: Solid Earth, 125(10), e2020JB020199, doi:https://doi.org/10.1029/2020JB020199.

Monnier, C., J. Girardeau, L. Le Mée, and M. Polvé (2006), Along-ridge petrological segmentation of the mantle in the Oman ophiolite, Geochemistry, Geophysics, Geosystems, 7(11), doi:https://doi.org/10.1029/2006GC001320.

Nasir, S., A. R. Al Sayigh, A. Al Harthy, S. Al-Khirbash, O. Al-Jaaidi, A. Musllam, A. Al-Mishwat, and S. AlBu'saidi (2007), Mineralogical and geochemical characterization of listwaenite from the Semail Ophiolite, Oman, Geochemistry, 67(3), 213-228, doi:https://doi.org/10.1016/j.chemer.2005.01.003.

Nicolas, A., F. Boudier, B. Ildefonse, and E. Ball (2000), Accretion of Oman ophiolite and United Emirates ophiolite. Discussion of a new structural map, Marine Geophys. Res., 21, 147-179.

Noel, J., M. Godard, E. Oliot, I. Martinez, M. Williams, F. Boudier, O. Rodriguez, C. Chaduteau, S. Escario, and P. Gouze (2018), Evidence of polygenetic carbon trapping in the Oman Ophiolite: petro-structural, geochemical, and carbon and oxygen isotope study of the Wadi Dima harzburgite-hosted carbonates (Wadi Tayin massif, Sultanate of Oman), Lithos, 323(Special issue "Geological reactive systems from the mantle to the abyssal sub-seafloor", Godard, M., Fumagalli, P., Jamtveit, B., Menez., B., eds.), 218-237, doi:210.1016/j.lithos.2018.1008.1020.

Oberhänsli, R., A. S. Wendt, B. Goffé, and A. Michard (1999), Detrital chromites in metasediments of the EastArabian continental margin in the Saih Hatat area: constraints for the palaeogeographic setting of the Hawasina and Semail basins (Oman Mountains), International Journal of Earth Sciences, 88(1), 13-25, doi:10.1007/s005310050242.

Paulick, H., W. Bach, M. Godard, C.-J. Hoog, G. Suhr, and J. Harvey (2006), Geochemistry of abyssal peridotites (Mid-Atlantic Ridge, $15^{\circ} 20^{\prime} \mathrm{N}$, ODP Leg 209): Implications for fluid/rock interaction in slow spreading environments, Chem. Geol., 234, 179-210.

Pearce, J. A., T. Alabaster, A. W. Shelton, and M. P. Searle (1981), The Oman ophiolite as a cretaceous arc-basin complex : evidence and implications, Phil. Trans. R. Soc. Lond., A300, 299-317.

Peters, D., A. Bretscher, T. John, M. Scambelluri, and T. Pettke (2017), Fluid-mobile elements in serpentinites: Constraints on serpentinisation environments and element cycling in subduction zones, Chemical Geology, 466, 654-666, doi:https://doi.org/10.1016/j.chemgeo.2017.07.017.

Peters, T. J., A. Nicolas, and R. G. Coleman (Eds.) (1991), Ophiolite genesis and evolution of the oceanic lithosphere, 903 pp., Kluwer Academic Press, Dordrecht, Boston, London.

Peuble, S., M. Godard, P. Gouze, R. Leprovost, I. Martinez, and S. Shilobreeva (2019), Control of CO2 on flow and reaction paths in olivine-dominated basements: An experimental study, Geochim. Cosmochim. Acta, 252, 16-38, doi:10.1016/j.gca.2019.1002.1007.

Peuble, S., M. Godard, L. Luquot, P. Gouze, and I. Martinez (2015), $\mathrm{CO}_{2}$ geological storage in olivine rich basaltic aquifers: New Insights from flow-through experiments, Applied Geochemistry, 52, 174-190; doi:110.1016/j.apgeochem.2014.1011.1024.

Plank, T. (2014), The Chemical Composition of Subducting Sediments, in Treatise on Geochemistry (Second Edition), edited by H. D. Holland and K. K. Turekian, pp. 607-629, Elsevier, Oxford, doi:https://doi.org/10.1016/B978-0-08-095975-7.00319-3.

Plank, T., K. Kelley, R. Murray, and L. Q. Stern (2007), Chemical composition of sediments subducting at the IzuBonin trench, Geochemistry, Geophysics, Geosystems, 8(4), doi:https://doi.org/10.1029/2006GC001444.

Plank, T., and J. N. Ludden (1992), Geochemistry of sediments in the Argo Abyssal Plain at Site 765: A continental margin reference section for sediment recycling in subduction zone, in Proceedings of Ocean Drilling Program, 
Scientific Results, vol. 123, edited by F. M. Gradstein, J. N. Ludden and A. C. Adamson, pp. 167-189, doi: 110.2973/odp.proc.sr.2123.2158.1992, Ocean Drilling Program, College Station, Texas.

Power, I. M., A. L. Harrison, G. M. Dipple, S. A. Wilson, P. B. Kelemen, M. Hitch, and G. Southam (2013), Carbon Mineralization: From Natural Analogues to Engineered Systems, Reviews in Mineralogy and Geochemistry, 77(1), 305-360, doi:10.2138/rmg.2013.77.9.

Prigent, C., P. Agard, S. Guillot, M. Godard, and B. Dubacq (2018a), Mantle wedge (de)formation during subduction infancy: evidence from the base of the Semail ophiolitic mantle, J. Petrol., 59(11), 2061-2091, doi:2010.1093/petrology/egy2090.

Prigent, C., S. Guillot, P. Agard, D. Lemarchand, M. Soret, and M. Ulrich (2018b), Transfer of subduction fluids into the deforming mantle wedge during nascent subduction: Evidence from trace elements and boron isotopes (Semail ophiolite, Oman), Earth and Planetary Science Letters, 484, 213-228, doi:https://doi.org/10.1016/j.epsl.2017.12.008.

Rioux, M., J. Garber, A. Bauer, S. Bowring, M. Searle, P. Kelemen, and B. Hacker (2016), Synchronous formation of the metamorphic sole and igneous crust of the Semail ophiolite: New constraints on the tectonic evolution during ophiolite formation from high-precision U-Pb zircon geochronology, Earth and Planetary Science Letters, 451, 185-195, doi:https://doi.org/10.1016/j.epsl.2016.06.051.

Rioux, M., J. M. Garber, M. P. Searle, P. Kelemen, S. Miyashita, Y. Adachi, and S. Bowring (2021), High-Precision U-Pb Zircon Dating of Late Magmatism in the Samail Ophiolite: A Record of Subduction Initiation, Journal of Geophysical Research: Solid Earth, 126(5), e2020JB020758, doi:https://doi.org/10.1029/2020JB020758.

Rose, G. (1837), Mineralogisch-geognostiche Reise nach dem Ural, dem Altai und dem Kaspischen Meere, in Reise nach dem nordlichen Ural und dem Altai - Volume 1, edited by G. E. Reimer, Verlag der Sanderschen Buchhandlung, Berlin (Germany).

Salters, V. J. M., and A. Stracke (2004), Composition of the depleted mantle, Geochemistry, Geophysics, Geosystems, 5(5), doi:https://doi.org/10.1029/2003GC000597.

Schroeder, T., W. Bach, N. Jöns, S. Jöns, P. Monien, and A. Klügel (2015), Fluid circulation and carbonate vein precipitation in the footwall of an oceanic core complex, Ocean Drilling Program Site 175, Mid-Atlantic Ridge, Geochemistry, Geophysics, Geosystems, 16(10), 3716-3732, doi:https://doi.org/10.1002/2015GC006041.

Searle, M. P., and J. Cox (1999), Tectonic setting, origin, and obduction of the Oman ophiolite, GSA Bulletin, 111(1), 104-122, doi:10.1130/0016-7606(1999)111<0104:tsoaoo>2.3.co;2.

Searle, M. P., and J. Malpas (1980), Structure and metamorphism of rocks beneath the Semail ophiolite of Oman and their significance in ophiolite obduction, Transactions of the Royal Society of Edinburgh: Earth Sciences, 71(4), 247-262, doi:10.1017/S0263593300013614.

Searle, R. C. (2019), Geology of the Oman Mountains, Eastern Arabia, 478 pp., Springer, doi:10.1007/978-3-03018453-7.

Seyfried, W. E., D. I. Foustoukos, and Q. Fu (2007), Redox evolution and mass transfer during serpentinization: An experimental and theoretical study at 200 degrees C, 500 bar with implications for ultramafic-hosted hydrothermal systems at Mid-Ocean Ridges, Geochimica et Cosmochimica Acta, 71(15), 3872-3886, doi:10.1016/j.gca.2007.05.015.

Soret, M., P. Agard, B. Dubacq, A. Plunder, and P. Yamato (2017), Petrological evidence for stepwise accretion of metamorphic soles during subduction infancy (Semail ophiolite, Oman and UAE), Journal of Metamorphic Geology, 35(9), 1051-1080, doi:https://doi.org/10.1111/jmg.12267.

Spandler, C., and C. Pirard (2013), Element recycling from subducting slabs to arc crust: A review, Lithos, 170-171, 208-223, doi:210.1016/j.lithos.2013.1002.1016.

Stanger, G. (1985), Silicified serpentinite in the Semail nappe of Oman, Lithos, 18, 13-22, doi:https://doi.org/10.1016/0024-4937(85)90003-9.

Takazawa, E., T. Okayasu, and K. Satoh (2003), Geochemistry and origin of the basal lherzolites from the northern Oman ophiolite (northern Fizh block), Geochem. Geophys. Geosyst., 4(2), 1021, doi:1010.1029/2001GC000232.

Ulrich, M., M. Muñoz, S. Guillot, M. Cathelineau, C. Picard, B. Quesnel, P. Boulvais, and C. Couteau (2014), Dissolution-precipitation processes governing the carbonation and silicification of the serpentinite sole of the New Caledonia ophiolite, Contributions to Mineralogy and Petrology, 167(1), 952, doi:10.1007/s00410-013-0952-8.

Ulven, O. I., B. Jamtveit, and A. Malthe-Sørenssen (2014), Reaction-driven fracturing of porous rock, Journal of Geophysical Research: Solid Earth, 119(10), 7473-7486, doi:https://doi.org/10.1002/2014JB011102.

Villey, M., J. Le Metour, and X. De Gramont (1986), Geological map of Fanja, Sheet NF 40-3F. Explanatory Notes, BRGM and Oman Ministry of Petroleum \& Minerals. 
Warren, C. J., R. R. Parrish, D. J. Waters, and M. P. Searle (2005), Dating the geologic history of Oman's Semail ophiolite: insights from U-Pb geochronology, Contrib. Mineral. Petrol., 150(DOI 10.1007/s00410-005-0028-5), 403-422.

Wilde, A., L. Simpson, and S. Hanna (2002), Preliminary study of Cenozoic hydrothermal alteration and platinum deposition in the Oman Ophiolite, Journal of the Virtual Explorer, 6, 7-13.

Wilson, A. (1960), The micro-determination of ferrous iron in silicate minerals by a volumetric and a colorimetric method, Analyst, 85, 823-827.

Yoshikawa, M., M. Python, A. Tamura, S. Arai, E. Takazawa, T. Shibata, A. Ueda, and T. Sato (2015), Melt extraction and metasomatism recorded in basal peridotites above the metamorphic sole of the northern Fizh massif, Oman ophiolite, Tectonophysics, 650, 53-64, doi:https://doi.org/10.1016/j.tecto.2014.12.004. 
†Oman Drilling Project Phase 1 Science Party

Jürg Matter, University of Southampton, United Kingdom

Damon Teagle, University of Southampton, United Kingdom

Jude Coggon, University of Southampton, United Kingdom

Michelle Harris, Plymouth University, United Kingdom

Emma Bennett, Cardiff University, United Kingdom

Nico Bompard, University of Southampton, United Kingdom

Marine Boulanger, Centre de Recherches Pétrographiques et Géochimiques, France

Lyderic France, Université de Lorraine, France

Gretchen Früh-Green, ETH Zurich, Switzerland

Dieter Garbe-Schönberg, Christian-Albrecht University of Kiel, Germany

Benoit Ildefonse, Université de Montpellier, France

Ana Jesus, German University of Technology in Oman, Oman

Jürgen Koepke, Leibniz University Hannover, Germany

Louise Koornneef, Plymouth University, United Kingdom

Romain Lafay, University of Lausanne, Switzerland

Johan Lissenberg, Cardiff University, United Kingdom

Chris MacLeod, Cardiff University, United Kingdom

Dominik Mock, Leibniz University of Hanover, Germany

Tony Morris, Plymouth University, United Kingdom

Samuel Müller, Kiel University, Germany

Julie Noël, Université de Montpellier, France

Daniel Nothaft, University of Colorado, USA

Americus Perez, Kanazawa University, Japan

Philippe Pezard, Université de Montpellier, France

Nehal Warsi, AZD Engineering, Oman

David Zeko, University of British Columbia, Canada

Barbara Zihlmann, University of Southampton, United Kingdom

Mohamed-Amine Bechkit, Houari Boumedienne University, Algeria

Laurent Brun, University of Montpellier, France

Bernard Célérier, University of Montpellier, France

Gilles Henry, University of Montpellier, France

Jehanne Paris, University of Montpellier, France

Gérard Lods, University of Montpellier, France

Pascal Robert, Université de Lorraine, Nancy, France

Salim Al Amri, Ministry of Regional Municipalities and Water Resources, Sultanate of Oman

Mohsin Al Shukaili, Ministry of Regional Municipalities and Water Resource, Sultanate of Oman

Ali Al Qassabi, Ministry of Regional Municipalities and Water Resources, Sultanate of Oman

Kyaw Moe, Japan Agency for Marine-Earth Science and Technology (JAMSTEC), Japan

Yasu Yamada, Japan Agency for Marine-Earth Science and Technology (JAMSTEC), Japan

Eiichi Takazawa, Niigata University, Japan

Katsuyoshi Michibayashi, Shizuoka University, Japan

Natsue Abe, JAMSTEC, Japan

Tetsu Akitou, Okayama University, Japan

Salim Ahmed AlShahri, Public Authority for Mining, Oman

Hamood Hamed Shames Al-Siyabi, MRMWR, Oman

Saif Masoud Alhumaimi, Public Authority for Mining, Oman

Maqbool Hussein AlRawahi, MRMWR, Oman

Musaab Shaker Al Sarmi, Sultan Qaboos University, Oman

Bader Hamed Alwaeli, Sultan Qaboos University, Oman

Andreas Beinlich, Curtin University, Australia

Elliot Carter, University of Manchester, United Kingdom

Mike Cheadle, University of Wyoming, USA

Mark Cloos, University of Texas at Austin, USA

Matthew Cooper, University of Southampton, United Kingdom

Laura Crispini, University of Genova, Italy 
Joëlle D’Andres (was Ducommun), Australian National University, Australia

Luke Deamer, Cardiff University, United Kingdom

Jeremy Deans, University of Southern Mississippi, USA

Kathi Faak, Ruhr-Universitaet Bochum, Germany

Rebecca Greenberger, California Institute of Technology, USA

Yumiko Harigane, National Institute of Advanced Industrial Science and Technology, Japan

Kohei Hatakeyama, Hiroshima University, Japan

Andrew Horst, Marshall University, USA

Takashi Hoshide, Akita University, Japan

Keisuke Ishii, Niigata University, Japan

Kevin Johnson, University of Hawaii, USA

Michael Kettermann, Aachen University, Germany

Hogyum Kim, Seoul National University, Republic of Korea

Jürgen Koepke, Leibniz University Hannover, Germany

Kentaro Kondo, Akita University, Japan

Alissa Kotowski, University of Texas at Austin, USA

Fatna Kourim, Academia Sinica, Taiwan

Yuki Kusano, Geological Survey of Japan, Japan

Catriona Menzies, University of Southampton, United Kingdom

Tomoaki Morishita, Kanazawa University, Japan

Tony Morris, Plymouth University, United Kingdom

Du Khac Nguyen, Kanazawa University, Japan

Toshio Nozaka, Okayama University, Japan

Keishi Okazaki, JAMSTEC, Japan

Suzanne Picazo, University of Lausanne, Switzerland

Ryoko Senda, Kyushu University, Japan

Yamato Tateishi, Okayama University, Japan

Jessica Till, University of Iceland, Iceland

Susumu Umino, Kanazawa University, Japan

Janos Urai, Aachen University, Germany

Yoichi Usui, JAMSTEC, Japan 


\section{QAGUPUBLICATIONS}

Journal of Geophysical Research - Solid Earth

Supporting Information for

\section{Geochemical Profiles Across the Listvenite- Metamorphic Transition in the Basal Megathrust of the Semail Ophiolite: Results from Drilling at Oman DP Hole BT1B}

M. Godard ${ }^{1 *}$, E. J. Carter ${ }^{2}$, R. Lafay ${ }^{1}$, E. Bennett ${ }^{3}$, F. Kourim ${ }^{4}$, J.-C. de Obeso ${ }^{5}$, K. Michibayashi ${ }^{6}$, M. Harris $^{7}$, J. Coggon ${ }^{8}$, D. Teagle ${ }^{8}$, P. Kelemen ${ }^{5}$ and the Oman Drilling Project Phase 1 Science Party

${ }^{1}$ Géosciences Montpellier, CNRS, Université de Montpellier, Montpellier, France

2 University of Manchester, Department of Earth and Environmental Sciences, Manchester, United Kingdom Now at: Department of Geology, Trinity College Dublin, Dublin 2, Ireland

${ }^{3}$ Cardiff University, Earth and Ocean Sciences, School of Earth and Ocean Sciences, Cardiff, United Kingdom

${ }^{4}$ Academia Sinica, Institute of Earth Science, Taipei, Taiwan

${ }^{5}$ LDEO, Columbia University, Palisades, NY, United States

${ }^{6}$ Dep. Earth and Planetary Sciences, Graduate School of Environmental Studies, Nagoya University, Nagoya, Japan

${ }^{7}$ School of Geography, Earth and Environmental Sciences, Plymouth University, Plymouth, United Kingdom

${ }^{8}$ School of Ocean \& Earth Science, University of Southampton, United Kingdom 


\title{
Contents of this file
}

Text S1. Analytical Methods

Text S2

Figure S1

Table S4

\section{Additional Supporting Information (Files uploaded separately)}

\author{
Captions for Tables S1 to S3 \\ Caption for Dataset S1
}

\section{Introduction}

Supporting information comprise a detailed description of the analytical techniques used to acquire the dataset presented in this article (Text S1 and Table S1), the compiled composition shown for comparison in Figures 2 and 3 (Table S2), and used for mass balance calculations (Table S3) and the details of the method used for mass balance calculations (Text S2, Figure S1). The lithology and depth of the studied samples and their major, trace and volatile element concentrations are reported as Supplementary Dataset S1. 


\section{Text S1. Analytical methods}

The major element composition of Hole BT1B samples was determined by X-ray fluorescence (XRF) on-board D/V Chikyu for the drillsite and shipboard samples and at GeoLabs (Ontario, Canada) for consortium samples. The volatile element composition of the drillsite and shipboard samples was determined by combustion CHNS elemental analysis (EA) and coulometry on-board D/V Chikyu. The trace element composition of the drillsite, shipboard and consortium samples was analyzed by Inductively-Coupled-Plasma-Mass Spectrometry (ICP-MS) at Géosciences Montpellier (France). The preparation and analytical procedures used to determine the geochemistry of the drillsite, shipboard and consortium samples are described below. The main mineralogical characteristics of the studied samples and their major, trace and volatile element concentrations are reported as Supplementary Dataset S1.

\section{Sample preparation and bulk geochemical analyses on-board D/V Chikyu}

The analytical procedures used to determine the compositions of the 74 drillsite and shipboard samples on-board D/V Chikyu, as well as the precision and accuracy of the methods are reported in detail in the Methods (Phase 1 Leg 2) of Kelemen et al [2020], and summarized as follows.

After removal of potential surface contamination due to drilling and sawing, the samples were rinsed several times in MilliQ water until the water ran clear. Drillsite and shipboard samples were powdered using a bench-top RocklabsTM chrome-steel ring mill (University of Southampton), and a Fritsch Pulverisette 5 Planetary Mill with agate grinding bowls and agate balls (on-board D/V Chikyu), respectively.

Major oxide $\left(\mathrm{SiO}_{2}, \mathrm{TiO}_{2}, \mathrm{Al}_{2} \mathrm{O}_{3}, \mathrm{Fe}_{2} \mathrm{O}_{3}, \mathrm{MnO}, \mathrm{MgO}, \mathrm{CaO}, \mathrm{Na}_{2} \mathrm{O}, \mathrm{K}_{2} \mathrm{O}, \mathrm{P}_{2} \mathrm{O}_{5}\right)$ and trace element ( $\mathrm{V}, \mathrm{Cr}, \mathrm{Ni}, \mathrm{Cu}, \mathrm{Zn}, \mathrm{Zr}$ ) abundances were measured on a RIGAKU Supermini wavelength dispersive XRF spectrometer equipped with a $200 \mathrm{~W}$ Pd anode tube at $50 \mathrm{kV}$ and $4 \mathrm{~mA}$ using glass beads and pressed powder pellets respectively. Samples were first ignited at $1000{ }^{\circ} \mathrm{C}$ to determine loss on ignition (LOI). Glass beads were prepared by mixing ignited powders with lithium metaborate flux and heating the mixture to $1150^{\circ} \mathrm{C}$ using the TK-4100 (Tokyo-Kagaku) automated bead maker. Pressed pellets were prepared with unignited rock powders using a Spex SamplePrep 3630 X-Press. Because on its low concentration in listvenites, serpentinites and ophicarbonates, $\mathrm{K}_{2} \mathrm{O}$ was often below detection limit when using beads and, when possible, we reported the values measured on pellets recalculated as volatile free. Shipboard XRF analyses for $\mathrm{V}, \mathrm{Cr}$, and $\mathrm{Ni}$ were recalibrated using shorebased XRF data acquired on drillsite samples at the University of St. Andrews (UK) following the approach described in Kelemen et al [2020].

The drillsite and shipboard samples were analyzed for total concentrations in $\mathrm{H}$ and $\mathrm{C}$ (noted TH and TC respectively, also expressed as $\mathrm{H}_{2} \mathrm{O}$ and $\mathrm{CO}_{2}$ in Supplementary Table S1, Supplementary Dataset S1 and Figure 2) using a Thermo Finnigan Flash EA 112 elemental analyser (EA), with rock powders combusted in an $\mathrm{O}_{2}$ rich environment within the EA prior to separation by Gas Chromatography. The fraction of carbon present as carbonates (Total Inorganic Carbon, $\mathrm{TIC}$ ) was determined using a Coulometerics $5012 \mathrm{CO}_{2}$ Coulometer coupled to a Carbonate Decomposition Device, in which carbonates from rock samples were dissolved by addition of $2 \mathrm{M} \mathrm{HCl}$, thus liberating $\mathrm{CO}_{2}$ for coulometric titration. TIC values are calculated assuming all carbonates are calcite, efficiently dissolved by $\mathrm{HCl}$. In the listvenite series where no calcite is present, magnesite was not dissolved and we posit that TIC corresponds to the carbon contained in dolomite. 
2 Preparation and bulk major element analysis of consortium samples

The 10 consortium samples were prepared for analysis in Lamont Doherty Earth Observatory. First all saw marks were removed with a Dremel tool using an aluminum oxide bit. After saw mark removal samples were scrubbed with a brush in deionized water and dried overnight. Samples were crushed and sieve to separate $\sim 4 \mathrm{~mm}$ chips, immediately rinsed with MilliQ water. After drying batches of chips of around $20 \mathrm{gr}$ were powdered in an alumina shatter box for 3 minutes to assure a smooth powder. The shatter box was cleaned with Ottawa sand and rinsed with deionized and MilliQ water between samples.

Major oxides $\left(\mathrm{SiO}_{2}, \mathrm{TiO}_{2}, \mathrm{Al}_{2} \mathrm{O}_{3}, \mathrm{Fe}_{2} \mathrm{O}_{3}, \mathrm{MnO}, \mathrm{MgO}, \mathrm{CaO}, \mathrm{Na}_{2} \mathrm{O}, \mathrm{K}_{2} \mathrm{O}, \mathrm{P}_{2} \mathrm{O}_{5}, \mathrm{Cr}_{2} \mathrm{O}_{3}\right)$ and a subset of trace elements (Co, $\mathrm{Cu}, \mathrm{Ni}, \mathrm{V}$ and $\mathrm{Zn}$ ) were analyzed by XRF by GeoLabs (Ontario, Canada). The samples were first run for LOI $\left(105^{\circ} \mathrm{C}\right.$ ( $\mathrm{N}$ atmosphere) then $\left.1000{ }^{\circ} \mathrm{C}\right)$. The ignited samples were then fused with a borate flux to produce the glass beads for analysis. Data obtained annually for Geo Labs' quality control materials are available at http://www.geologyontario.mndm.gov.on.ca/index.html.

\section{Determination of Fe(II)}

The FeO concentrations of 8 serpentinites and 21 Listvenites was quantified at the University of Lausanne (ISTE) following the Fe-titration protocol of Wilson [1960]. $200 \mathrm{mg}$ of non-ignited sample powder was dissolved in a $\mathrm{H}_{2} \mathrm{SO}_{4} / \mathrm{HF}$ solution with ammonium vanadate $\left(\mathrm{NH}_{4} \mathrm{VO}_{3}\right)$ to oxidize and complex all $\mathrm{Fe}(\mathrm{II})$ to $\mathrm{Fe}(\mathrm{III})$ with vanadium under controlled conditions. The complexed Fe(III) molecules were then reduced and the resulting Fe(II) complexed with a red indicator solution of 2,2'-dipyridil $\left(\mathrm{C}_{10} \mathrm{H}_{8} \mathrm{~N}_{2}\right)$ in a $\mathrm{H}_{3} \mathrm{BO}_{3} / \mathrm{CH}_{3} \mathrm{COONa}$ solution. The colored solution was analyzed using a UV/Vis Perkin Elmer Lambda 25 spectrophotometer and the Fe(II) concentration quantified with UV WinLab Software. Calibration was determined from a blank solution and 4 standards having FeO composition of 1.25 wt.\% (foid syenite NIM-L), 3.58 wt.\% (syenite SY-3), 5.17 wt.\% (diorite DR-N) and 8.63 wt.\% (gabbro MRG-1). The error on the analyses was below $3 \%$ of the absolute value and the reproducibility on samples and standards was better than $0.1 \mathrm{wt} . \%$.

\section{ICP-MS measurement of bulk trace element concentrations}

Trace element concentrations ( $\mathrm{Li}, \mathrm{Sc}, \mathrm{Ti}, \mathrm{V}, \mathrm{Mn}, \mathrm{Co}, \mathrm{Ni}, \mathrm{Cu}, \mathrm{Ga}, \mathrm{As}, \mathrm{Mo}, \mathrm{Sn}, \mathrm{Sb}, \mathrm{Rb}, \mathrm{Sr}, \mathrm{Y}$, $\mathrm{Zr}$, Nb, Cs, Ba, Rare Earth Elements (REE), Hf, Ta, Pb, Th, U, W, Tl) were determined at Géosciences Montpellier (AETE-ISO, OSU OREME, University of Montpellier, France) using an Agilent 7700X quadrupole ICP-MS. Unignited powder samples were analyzed after the $\mathrm{HF} / \mathrm{HClO}_{4}$ digestion procedure of lonov et al. [1992] using the measurement protocol described in Godard et al. [2000]. Prior to analysis, sample solutions were diluted in a $2 \% \mathrm{HNO}_{3}$ solution to a total dilution of 1000 for serpentinites and listvenites and of 2000 for schists and greenstones. An external calibration was used to determine concentrations for most elements. $\mathrm{Nb}$ and $\mathrm{Ta}$ concentrations were, in contrast, calibrated with internal standards ( $\mathrm{Zr}$ and $\mathrm{Hf}$ concentrations respectively), a surrogate calibration method adapted from Jochum et al. [1990] to minimize memory effects due to the introduction of concentrated $\mathrm{Nb}$-Ta solutions in the instrument. The Helium cell gas mode of the Agilent 7700X was used to measure Sc, Ti, $\mathrm{V}$, $\mathrm{Mn}, \mathrm{Co}, \mathrm{Ni}, \mathrm{Cu}, \mathrm{Zn}, \mathrm{Ga}, \mathrm{As}, \mathrm{Sr}$, Sn and $\mathrm{Sb}$ while removing polyatomic interferences. Each ICP-MS measurement is an average of three runs and its precision is determined by the standard deviation. The uncertainty of analysis was estimated for each sample using an error propagation approach, which takes into account the precision of the measurements of (i) the instrumental blank, (ii) the procedural blanks and (iii) the sample analysis. Analyses (i) below 
the instrument detection limit, (ii) for which the contribution of the procedural blank is $>70 \%$ or (iii) having uncertainties $>50 \%$ were eliminated (noted "not determined"). The external precision and accuracy of analyses was assessed by repeated analyses of certified reference materials: serpentinite UB-N, dunite DTS- 2 b, peridotite JP- 1 , basalts BIR-1 and BHVO-2, and slate OU-6. The limit of detection of the instrument, the average values of the procedural blanks and rock standards obtained during this study are reported in Table S1.

The concentrations of the subset of elements measured using both ICPMS and XRF were consistent within the instrumental uncertainties, except for $\mathrm{Zr}$ that had concentrations significantly lower for the samples from the metamorphic sole when measured by ICPMS compared to XRF. $\mathrm{Zr}$ and $\mathrm{Hf}$ also showed unexpectedly low values compared to $\mathrm{Ti}$ and neighboring elements. This depletion reveals incomplete digestion of Zr-bearing refractory phases, probably zircon, a mineral present in the amphibolites from the metamorphic sole of the Semail ophiolite [Ishikawa et al., 2005; Rioux et al., 2016]. Zr and Hf were eliminated from the ICPMS dataset for the metamorphic sole at Hole BT1B.

\section{References}

Godard, M., D. Jousselin, and J.-L. Bodinier (2000), Relationships between geochemistry and structure beneath a palaeo-spreading centre: A study of the mantle section in the Oman Ophiolite, Earth Planet. Sci. Lett., 180, 133-148.

Ionov, D. A., L. Savoyant, and C. Dupuy (1992), Application of the ICP-MS technique to trace element analysis of peridotites and their minerals, Geostand. Newslett., 16, 311-315.

Ishikawa, T., S. Fujisawa, K. Nagaishi, and T. Masuda (2005), Trace element characteristics of the fluid liberated from amphibolite-facies slab: Inference from the metamorphic sole beneath the Oman ophiolite and implication for boninite genesis, Earth Planet. Sci. Lett., 240, 355-377.

Jochum, K. P., U. Nohl, K. Herwig, E. Lammel, B. Stoll, and A. W. Hofmann (2007), GeoRem: A new geochemical database for reference materials and isotopic standards, Geostandards and Geoanalytical Research, 29(3), 333-338; doi:310.1111/j.1751-1908X.2005.tb00904.x.

Jochum, K. P., H. M. Seufert, and M. F. Thirwall (1990), High-sensitivity Nb analysis by sparksource mass spectrometry (SSMS) and calibration of XRF Nb and Zr, Chem. Geol., 81, 1-16.

Kelemen, P. B., J. M. Matter, D. A. H. Teagle, J. A. Coggon, and the Oman Drilling Project Science Team (2020), Proceedings of the Oman Drilling Project, College Station, TX.

Rioux, M., J. Garber, A. Bauer, S. Bowring, M. Searle, P. Kelemen, and B. Hacker (2016), Synchronous formation of the metamorphic sole and igneous crust of the Semail ophiolite: New constraints on the tectonic evolution during ophiolite formation from high-precision $\mathrm{U}_{-}$ $\mathrm{Pb}$ zircon geochronology, Earth and Planetary Science Letters, 451, 185-195, doi:https://doi.org/10.1016/j.epsl.2016.06.051.

Wilson, A. (1960), The micro-determination of ferrous iron in silicate minerals by a volumetric and a colorimetric method, Analyst, 85, 823-827. 


\section{Text S2. Mass balance calculations}

\section{Mass balance approach}

Mass balance calculations have been carried out using the isocon approach of Baumgartner and Olsen [1995] using a fortran code made available by the authors. The isocon method operates by comparing the composition of a given protolith and altered rock and fitting a line of immobility (an isocon) to a set of elements. The slope and intercept of this line then define the total mass gain or loss of the system. Any element not collinear with the isocon (to within uncertainty) is mobile and either lost or gained from the system. The choice of immobile elements to include in the isocon is subjective and cannot be determined by the fitting scheme. Rather, the fortran code of Baumgartner and Olsen [1995] calculates all possible isocons, corresponding to all combinations of elements which are collinear, to within uncertainty, when plotted. From these we have in each case chosen the isocon with the most elements included since: (a) we expect most elements to be relatively immobile during fluid processes; (b) if a large number of elements are collinear and therefore apparently immobile, it is more likely that this state has arisen because they are indeed immobile than that they have all shown identical patterns of mobility; (c) using this approach the same set of elements consistently appear as immobile where the appropriate protolith of each group is chosen (MMS for Serpentinites and Listvenites I and III, basal/amphibole Iherzolites for Listvenite II); (d) including all possible elements rather than subjectively judging $X$ to be immobile is the least subjective approach leading the most comparable results between different protolith-altered rock pairings; and lastly (e) including all possible elements means that all potentially immobile elements contribute to the calculation of the uncertainty of slope/intercept of the line of immobility (see below). Alternative isocon plots illustrating which elements are considered mobile and immobile for each calculation are shown in Figure S1.

2 Mass and volume changes and associated uncertainties

An isocon calculated for a given protolith defines a particular mass gain/loss. Uncertainties associated with calculated mass gain/loss are calculated from the region of overlap of the various uncertainties of the elements considered immobile in the calculation (see Baumgartner and Olsen [1995] for a graphical depiction). The uncertainty in the mass change therefore corresponds to the locus of all possible isocons for a particular set of immobile elements and their associated variances in protolith and altered rock. There is therefore some subjectivity associated with the choice of immobile elements and as a result the calculated uncertainty should best be viewed as the uncertainty given the assumption of $a$ given protolith and a given set of immobile elements. As detailed above, we tried to avoid this subjectivity as far as possible by defining our isocon as that which fit the largest number of elements.

\section{Data preparation}

Inputs for mass balance calculations consist of the average composition of a potential protolith and the altered rock. These average compositions were specified as log means and standard deviations, since data are log normally distributed for many elements:

$\log$ mean $=$ mean $\left[\log _{10}(\right.$ concentration $\left.)\right]$

$\log \mathrm{SD}=\mathrm{SD}\left[\log _{10}(\right.$ concentration$\left.)\right]$ 
Regardless of this, in the case of normally distributed data, the log normal mean and standard deviation converge on their normal counterparts. All anhydrous major element data were recalculated to include the contribution of volatiles (measured as LOI) in their totals since volatile elements are considered as mobile components in the mass balance calculation. $\mathrm{H}_{2} \mathrm{O}$ and $\mathrm{CO}_{2}$ were directly measured in $\mathrm{BT} 1 \mathrm{~B}$ samples while for the Semail ophiolite database we have assumed all LOI constitutes $\mathrm{H}_{2} \mathrm{O}$. Although $\mathrm{CO}_{2}$ is negligible in serpentinized peridotites, a zero value causes errors with the calculation of log normal statistics so and we have estimated a nominal mean $\mathrm{CO}_{2}$ of $0.1 \mathrm{wt}$. \% (log mean $\left.=-1 \pm 0.1\right)$ for all protoliths. Similarly, for Listvenite II, all Th data coincidentally had the same value resulting in a standard deviation of 0 . To avoid errors this introduced in the code a nominal log standard deviation of 0.3 was given, similar to that of Listvenites I and III. For Serpentinite III there was only one sample for which $\mathrm{H}_{2} \mathrm{O}$ and $\mathrm{CO}_{2}$ were measured directly so these were estimated for other samples using linear regressions of $\mathrm{H}_{2} \mathrm{O}$ and $\mathrm{CO}_{2}$ against $\mathrm{LOI}$ from all BT1B samples and the results used to calculate statistics. Data for $\mathrm{Na}_{2} \mathrm{O}, \mathrm{P}_{2} \mathrm{O}_{5}$ were omitted since there were a large number of data below detection limit. XRF bead data for $\mathrm{Cr}_{2} \mathrm{O}_{3}, \mathrm{MnO}$ and $\mathrm{TiO}_{2}$ were omitted in favour of data from XRF pellets or ICP-MS with the latter always taken were both were available. For Semail ophiolite samples from the literature where ICP-MS trace element data was not available in the Oman ophiolite database, XRF pellet data was substituted where possible (including $\mathrm{Sc}, \mathrm{Ti}, \mathrm{Cr}$, $\mathrm{V}, \mathrm{Co}, \mathrm{Cu}, \mathrm{Zn}$ and $\mathrm{Mn}$ ). Individual rare-earth elements were not included in the calculations to avoid giving undue weight to this group of elements. Instead, totals for light, middle and heavy rare-earths (LREE, MREE, and HREE) were used in the mass balance calculations.

\section{Results of mass balance}

The BT1B listvenite series were divided into 3 listvenite domains (Listvenites I-III) and two serpentinites (Serpentinites I and III) from within the upper- and lower-most listvenite groups. For each of these 5 lithological domains, an isocon and associated mass balance calculations were made assuming the protolith had the composition of main mantle section (MMS) Semail peridotites (Supplementary Table S3).

For listvenite II this provided a pattern of mobility inconsistent with that seen in listvenite I and III and showed non-colinearity for several typically immobile elements including $\mathrm{Ni}, \mathrm{Cr}, \mathrm{Co}, \mathrm{SiO}_{2}, \mathrm{MgO}, \mathrm{Al}_{2} \mathrm{O}_{3}$ on the one hand and LREE, MREE, $\mathrm{HREE}, \mathrm{Ti}, \mathrm{Zr}, \mathrm{Hf}$, and $\mathrm{Y}$ on the other. This indicates that, if the protolith for listvenite II was MMS then one of these sets of elements must be quite highly mobile during carbonation, in contrast to the patterns seen in listvenite I and III where all these elements lie collinear (to within uncertainty) and form a single isocon.

An alternative explanation is that the protolith for listvenite II did not have the composition of MMS. To test this, a second mass-balance calculation was made with the composition of basal Iherzolites and basal amphibole Iherzolites as the protolith (Supplementary Table S3). Both of these more fertile basal peridotite lithologies were combined in the calculation of an average composition. This was justified on the basis that the exact protolith is unknown and that there are relatively few data for these lithologies. Using a combined average composition of therefore gives a more realistic estimate of the uncertainty in protolith composition and propagates this to calculations of mass gain/loss. With basal peridotites as the protolith, Listvenite II shows a very similar pattern of mobility to listvenites I and III with the majority of element defining a single isocon and pronounced gain of fluid mobile elements including $\mathrm{Pb}, \mathrm{Cs}, \mathrm{Rb}, \mathrm{Ba}, \mathrm{Li}, \mathrm{K}_{2} \mathrm{O}$ and $\mathrm{Sr}$. 
It should be noted that apparent mobility of elements may be due to genuine mobile behaviour or, alternatively, can arise as a result of an inappropriate protolith composition. One example of the latter may be Th, which appears to as mobile in several calculations (with a net loss from the system), in contrast to it expected immobile behaviour (Fig. S1). This is most marked in the case of Serpentinite II with basal Iherzolites and amphibole Iherzolites as the protolith. Due to the lack of available data from these lithologies, the Th content of the protolith in this case is based on only 8 samples. The same is true of $\mathrm{Nb}$ and $\mathrm{Ta}$ and may explain their anomalous behavior too.

\section{References}

Baumgartner, L.P., Olsen, S.N. (1995). A least-squares approach to mass transport calculations using the isocon method. Economic Geology, 90(5): 1261-1270.

Figure S1. (Next page) Isocon plots for listvenite series from Hole BT1B comparing the average composition of listvenites and serpentinites from each listvenite domains with potential protolith compositions on log-log scales. Plotted on each panel is an isocon (line of immobility, dotted black lines), each corresponding to a protolith-altered rock pair. Elements are color coded as mobile (grey) and immobile (red) with immobile elements defining the position and uncertainty of the isocon (and associated calculated mass changes). Isocons were calculated using the approach of Baumgartner and Olsen [1995]. The 1:1 reference line in grey on each panel corresponds to zero mass change during alteration. Isocons above and below this indicate mass loss and gain, respectively. Using the average compion of the MMS refractory peridotites as the protolith composition for each domain, this approach gives consistent patterns of mobile and immobile elements, with the exception of Listvenites II where two potential isocons are apparent in the data (each plotted separately and labeled A and B). Mass balance was repeated for Listvenite II with the average composition of basal Iherzolites (including amphibole-bearing lherzolites) which gives a single consistent isocon and similar patterns of mobility/immobility to the other panels. Modeled protolith compositions and statistics are in Supplementary Table S3. 
Listvenite domain I

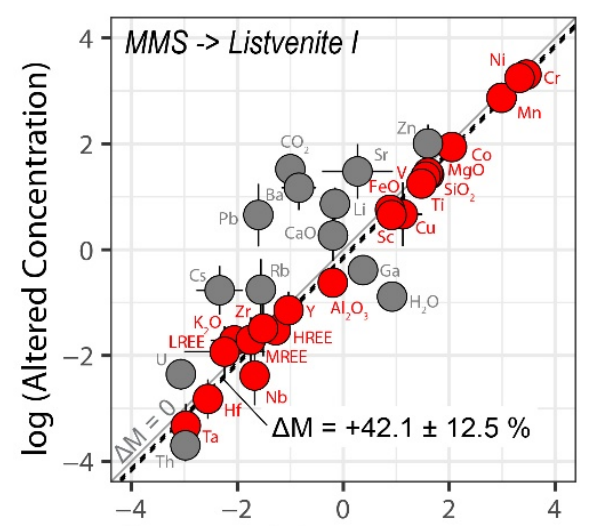

log (Protolith Concentration)

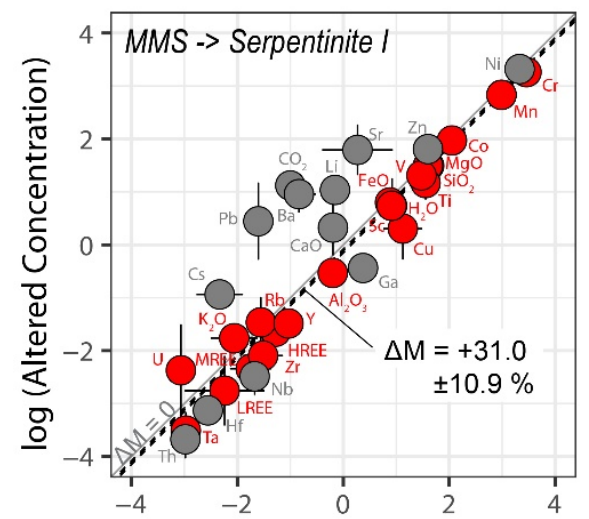

log (Protolith Concentration)
Listvenite domain II
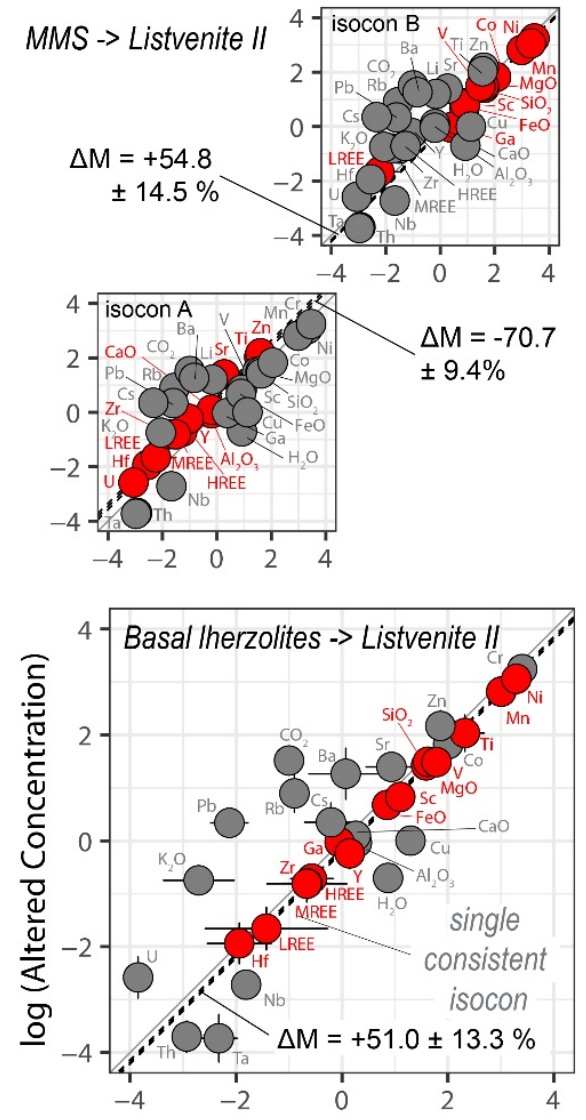

log (Protolith Concentration)
Listvenite domain III
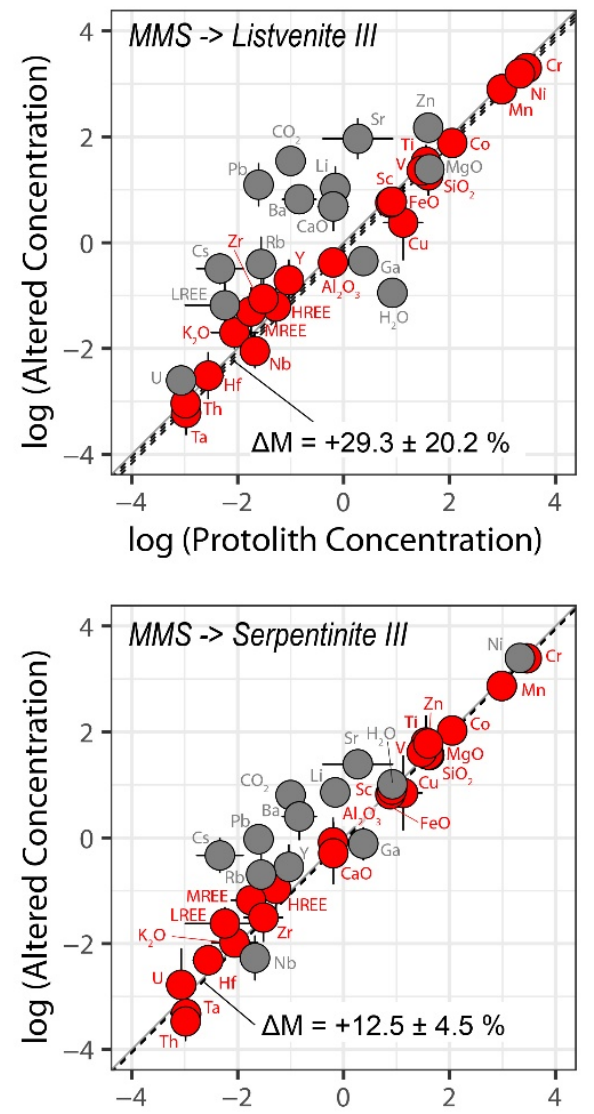

log (Protolith Concentration) 
Table S4. Summary of mass (wt.\%) and volume (vol.\%) changes associated with $\mathrm{CO}_{2}$ metasomatism. Changes in mass were determined from mass balance calculations using the approach of Baumgartner and Olsen [1995]. These were converted to volume changes using a density of $2.81 \pm 0.50 \mathrm{~g} . \mathrm{cm}^{-3}$ for serpentinised peridotite protoliths [Dewandel, 2002] and the mean density of listvenite and serpentinite measured in BT1B cores, $2.86 \pm 0.07 \mathrm{~g}_{\mathrm{cm}} \mathrm{cm}^{-3}$ and $2.52 \pm 0.05 \mathrm{~g} . \mathrm{cm}^{-3}$, respectively [Kelemen et al., 2020] and propagating the associated uncertainties. For the listvenite or serpentinite of each domain, results are shown for the most appropriate protolith only (see Supporting Text S2 for details). MMS denotes main mantle section.

\begin{tabular}{ccccc} 
Listvenite Domain & Lithology & Protolith & Mass change & Volume change \\
\hline \multirow{2}{*}{ I } & Listvenite & MMS & $\mathbf{4 2 . 1} \pm \mathbf{1 2 . 5}$ & $41.3 \pm 14.4$ \\
& Serpentinite & MMS & $\mathbf{3 1 . 0} \pm \mathbf{1 0 . 9}$ & $34.6 \pm 13.6$ \\
\hline II & Listvenite & Basal lherzolites & $\mathbf{5 1 . 0} \pm \mathbf{1 3 . 3}$ & $50.1 \pm 15.9$ \\
\hline \multirow{2}{*}{ III } & Listvenite & MMS & $\mathbf{2 9 . 3} \pm \mathbf{2 0 . 2}$ & $28.8 \pm 20.5$ \\
& Serpentinite & MMS & $\mathbf{1 2 . 5} \pm \mathbf{4 . 5}$ & $13.9 \pm 5.6$ \\
\hline
\end{tabular}




\section{Captions to Supplementary Tables}

Table S1. Detection limit, procedural blank and trace element concentrations of certified rock standards, serpentinite UB-N, dunite DTS- $2 \mathrm{~b}$, peridotite JP-1, basalts BIR-1 and BHVO-2, and slate OU-6, determined by Q-ICP-MS at Géosciences Montpellier (AETE-ISO, France). Preferred values were determined from a compilation of literature values downloaded between 2019 and 2020 from http://georem.mpch-mainz.gwdg.de/ [Jochum et al., 2007]. Note: Mass: Mass used for ICP-MS analysis; DL: Detection Limit of the ICP-MS; Blank: Procedural Blank; $\sigma$ : standard deviation; Pref.Val.: Preferred values; N: average of N analyses; n.a. : not analyzed; n.d.: not determined.

Table S2. Summary statistics of the compiled composition of the Semail ophiolite mantle section peridotites subdivided by lithotypes. Concentrations are in wt.\% for major and volatile elements and in $\mu \mathrm{g} / \mathrm{g}$ for trace elements. Source of data: main mantle section (MMS) [GerbertGaillard, 2002; Godard et al., 2000; Hanghoj et al., 2010], basal Iherzolites [Lippard et al., 1986; Takazawa et al., 2003] and amphibole bearing basal Iherzolites [Khedr et al., 2014]). Abbreviations: N; number of analyses; Q16 and Q84: 16th and 84th percentiles about the median; SD: Standard deviation.

Table S3. Summary statistics of the compositions (including volatile elements) of the Semail ophiolite mantle and BT1B lithologies used in mass balance calculations. Where data were reported as anhydrous, they were re-calculated to include the volatile compositions. Concentrations are in wt.\% for major and volatile elements and in $\mu \mathrm{g} / \mathrm{g}$ for trace elements. Source of data: main mantle section (MMS) [Gerbert-Gaillard, 2002; Godard et al., 2000; Hanghoj et al., 2010], basal Iherzolites [Khedr et al., 2014; Lippard et al., 1986; Takazawa et al., 2003]. Abbreviations: N; number of analyses; SD: Standard deviation. 
Table S1: Trace element concentrations of serpentinite UB-N, dunite DTS-2b, peridotite JP-1, basalts BIR-1 and BHVO-2, and slate OU-6 determined by ICPMS at Géosciences Montpellier (AETE-ISO, France). Preferred values were determined from a compilation of litterature values downloaded between 2019 and 2020 from http://georem.mpch-mainz.gwdg.de/ (Jochum et al, 2007) .

\begin{tabular}{|c|c|c|c|c|c|c|c|c|c|c|c|c|c|c|c|c|c|c|c|c|}
\hline \multirow{3}{*}{ Element } & \multirow{3}{*}{ Mass } & \multirow{3}{*}{\begin{tabular}{|c|}
$\mathrm{DL}$ \\
$10^{-12} \mathrm{~g} / \mathrm{g}$
\end{tabular}} & \multirow{3}{*}{$\begin{array}{c}\text { Blank } \\
\mathrm{N}=10 \\
10^{-9} \mathrm{~g} / \mathrm{g}\end{array}$} & \multicolumn{3}{|c|}{ DTS-2b } & \multicolumn{3}{|c|}{ JP-1 } & \multicolumn{3}{|c|}{ UB-N } & \multicolumn{3}{|c|}{ BIR-1 } & \multicolumn{3}{|c|}{ BHVO-2 } & \multicolumn{2}{|c|}{ OU-6 } \\
\hline & & & & $N=4$ & $\sigma$ & Pref. Val. & $N=4$ & $\sigma$ & Pref. Val. & $N=10$ & $\sigma$ & Pref. Val. & $N=10$ & $\sigma$ & Pref. Val. & $N=6$ & $\sigma$ & Pref. Val. & $N=1$ & Pref. Val. \\
\hline & & & & $10^{-9} \mathrm{~g} / \mathrm{g}$ & $10^{-9} \mathrm{~g} / \mathrm{g}$ & $10^{-6} \mathrm{~g} / \mathrm{g}$ & $10^{-9} \mathrm{~g} / \mathrm{g}$ & $10^{-9} \mathrm{~g} / \mathrm{g}$ & $10^{-6} \mathrm{~g} / \mathrm{g}$ & $10^{-6} \mathrm{~g} / \mathrm{g}$ & $10^{-6} \mathrm{~g} / \mathrm{g}$ & $10^{-6} \mathrm{~g} / \mathrm{g}$ & $10^{-6} \mathrm{~g} / \mathrm{g}$ & $10^{-6} \mathrm{~g} / \mathrm{g}$ & $10^{-6} \mathrm{~g} / \mathrm{g}$ & $10^{-6} \mathrm{~g} / \mathrm{g}$ & $10^{-6} \mathrm{~g} / \mathrm{g}$ & $10^{-6} \mathrm{~g} / \mathrm{g}$ & $10^{-6} \mathrm{~g} / \mathrm{g}$ & $10^{-6} \mathrm{~g} / \mathrm{g}$ \\
\hline $\mathrm{Li}$ & 7 & 9.23 & 4.19 & 1888 & 299 & 1.98 & 1587 & 172 & 1.68 & 26.8 & 2.6 & 26.9 & 3.14 & 0.29 & 3.20 & 4.78 & 0.30 & 4.50 & 90.21 & 95.30 \\
\hline Sc & 45 & 0.44 & 2.46 & 3209 & 407 & 3.4 & 7237 & 674 & 7.4 & 12.07 & 0.61 & 13.1 & 41.74 & 1.94 & 43.2 & 29.02 & 1.17 & 31.8 & 20.07 & 23.1 \\
\hline $\mathrm{Ti}$ & 49 & 100.0 & 49.79 & 51553 & 5936 & 42.9 & 20789 & 2798 & 20.2 & 536.8 & 27.1 & 573.5 & 5521 & 219 & 5746 & 14600 & 297 & 16368 & 5531 & 5933 \\
\hline v & 51 & 4.07 & 3.47 & 23837 & 2410 & 19.6 & 27690 & 2881 & 25.5 & 63.0 & 5.4 & 68.9 & 332.6 & 17.9 & 320.6 & 304.5 & 23.8 & 318.2 & 121.9 & 129.8 \\
\hline $\mathrm{Mn}$ & 55 & 42.13 & 150.89 & 875195 & 62352 & 830 & 935993 & 61965 & 867 & 978 & 59 & 945 & 1370 & 55 & 1341 & 1348 & 37 & 1309 & 2307 & 2168 \\
\hline Co & 59 & 1.34 & 8.26 & 136177 & 9428 & 133.5 & 113578 & 8088 & 112.4 & 97.4 & 5.3 & 99.3 & 50.4 & 2.9 & 52.2 & 43.2 & 1.7 & 44.9 & 26.5 & 29.2 \\
\hline $\mathrm{Ni}$ & 62 & 8.24 & 119.48 & 3966510 & 318306 & 3902 & 2443082 & 157480 & 2420 & 1927 & 122 & 1944 & 172.8 & 11.3 & 168.9 & 128.9 & 7.6 & 119.8 & 37.4 & 40.2 \\
\hline $\mathrm{Cu}$ & 65 & 13.22 & 55.27 & 2802 & 513 & 3.06 & 4955.01 & 732.89 & 4.99 & 23.96 & 1.48 & 26.61 & 119.94 & 5.40 & 120.70 & 132.27 & 5.26 & 129.30 & 42.37 & 40.40 \\
\hline $\mathrm{Zn}$ & 66 & 74.26 & 1037.28 & 50353 & 531 & 47.21 & 44761.8 & 312.97 & 43.22 & 84.80 & 3.56 & 84.00 & 70.77 & 1.27 & 70.40 & 103.16 & 3.08 & 103.90 & 115.84 & 111.40 \\
\hline $\mathrm{Ga}$ & 71 & 0.11 & 1.05 & 1001.1 & 134.2 & 0.9300 & 546.00 & 62.39 & 0.50 & 2.469 & 0.146 & 3.023 & 14.48 & 0.50 & 15.46 & 20.85 & 0.80 & 21.37 & 23.93 & 24.17 \\
\hline As & 75 & 1.31 & 16.30 & n.d. & & 0.0875 & 431.50 & 118.23 & 0.32 & 9.259 & 0.666 & 10.735 & n.d. & 0.00 & 0.17 & n.d. & 0.00 & 0.70 & 14.80 & 13.23 \\
\hline $\mathrm{Rb}$ & 85 & 0.72 & 4.93 & 28.56 & 8.03 & 0.0251 & 279.50 & 15.85 & 0.35 & 3.046 & 0.182 & 3.633 & 0.18 & 0.01 & 0.21 & 8.44 & 0.29 & 9.26 & 115.89 & 121.30 \\
\hline $\mathrm{Sr}$ & 88 & 7.56 & 26.59 & 492.44 & 21.36 & 0.3669 & 570.40 & 13.56 & 0.61 & 7.218 & 0.290 & 8.067 & 100.18 & 1.47 & 108.60 & 361.09 & 4.25 & 394.10 & 121.37 & 131.70 \\
\hline Y & 89 & 0.15 & 1.33 & 37.37 & 1.25 & 0.0385 & 100.60 & 3.27 & 0.09 & 2.576 & 0.077 & 2.549 & 15.533 & 0.251 & 15.600 & 25.64 & 0.31 & 25.91 & 26.75 & 27.75 \\
\hline $\mathrm{Zr}$ & 90 & 8.89 & 7.67 & 170.08 & 24.13 & 0.2031 & 5535.10 & 166.01 & 5.41 & 3.539 & 0.124 & 3.724 & 14.520 & 0.242 & 14.800 & 174.00 & 1.20 & 171.20 & 149.27 & 174.20 \\
\hline $\mathrm{Nb}$ & 93 & 1.94 & 1.91 & 14.79 & 0.25 & 0.0176 & 40.39 & 2.05 & 0.044 & 0.060 & 0.006 & 0.060 & 0.600 & 0.021 & 0.553 & 19.81 & 0.40 & 18.10 & 12.69 & 14.49 \\
\hline $\mathrm{Cd}$ & 114 & 1.97 & 0.67 & 33.37 & 1.43 & 0.0733 & 135.45 & 3.84 & 0.134 & 0.327 & 0.020 & 0.385 & 0.052 & 0.005 & 0.068 & 1.08 & 0.15 & 4.07 & 0.42 & 0.00 \\
\hline Sn & 117 & 11.07 & 18.79 & 576.75 & 10.13 & 0.6548 & 40.80 & 7.88 & 0.036 & 0.192 & 0.008 & 0.328 & 0.664 & 0.025 & 0.701 & 1.81 & 0.02 & 1.78 & 2.32 & 2.67 \\
\hline $\mathrm{Sb}$ & 121 & 1.65 & 3.81 & 631.95 & 26.05 & 0.5380 & 46.45 & 4.77 & 0.037 & 0.205 & 0.010 & 0.203 & 0.455 & 0.016 & 0.462 & 0.154 & 0.009 & 0.10 & 0.53 & 0.56 \\
\hline Cs & 133 & 0.07 & 0.31 & 1.59 & 0.24 & 0.0058 & 37.35 & 0.76 & 0.044 & 10.38 & 0.31 & 10.96 & 0.006 & 0.001 & 0.006 & 0.090 & 0.003 & 0.10 & 6.95 & 8.10 \\
\hline $\mathrm{Ba}$ & 137 & 2.71 & 48.62 & 10883 & 409 & 11.6800 & 10155.8 & 258.7 & 10.32 & 26.13 & 1.71 & 26.29 & 5.966 & 0.182 & 6.750 & 120.5 & 1.7 & 130.9 & 428.7 & 480.0 \\
\hline La & 139 & 0.17 & 1.53 & 14.75 & 1.75 & 0.0120 & 30.09 & 1.21 & 0.033 & 0.331 & 0.018 & 0.329 & 0.609 & 0.022 & 0.627 & 15.26 & 0.28 & 15.20 & 32.17 & 33.20 \\
\hline $\mathrm{Ce}$ & 140 & 0.33 & 2.36 & 24.44 & 1.35 & 0.0246 & 59.23 & 2.59 & 0.065 & 0.755 & 0.035 & 0.813 & 1.737 & 0.057 & 1.920 & 34.59 & 0.66 & 37.53 & 70.88 & 77.10 \\
\hline $\operatorname{Pr}$ & 141 & 0.03 & 0.25 & 3.16 & 0.19 & 0.0032 & 7.59 & 0.38 & 0.009 & 0.112 & 0.005 & 0.120 & 0.343 & 0.013 & 0.372 & 4.888 & 0.107 & 5.339 & 7.27 & 7.91 \\
\hline $\mathrm{Nd}$ & 146 & 0.14 & 0.93 & 12.44 & 0.53 & 0.0142 & 30.90 & 1.92 & 0.035 & 0.577 & 0.025 & 0.611 & 2.193 & 0.074 & 2.397 & 22.53 & 0.58 & 24.27 & 27.36 & 30.20 \\
\hline Sm & 147 & 0.05 & 0.21 & 3.35 & 0.29 & 0.0028 & 8.25 & 0.83 & 0.009 & 0.204 & 0.008 & 0.216 & 1.010 & 0.041 & 1.113 & 5.505 & 0.116 & 6.023 & 5.40 & 6.01 \\
\hline $\mathrm{Eu}$ & 151 & 0.01 & 0.01 & 0.86 & 0.09 & 0.0010 & 2.20 & 0.14 & 0.002 & 0.077 & 0.003 & 0.082 & 0.491 & 0.014 & 0.520 & 1.960 & 0.054 & 2.043 & 1.18 & 1.36 \\
\hline Gd & 157 & 0.07 & 0.18 & 3.49 & 0.18 & 0.0039 & 9.85 & 0.43 & 0.011 & 0.314 & 0.012 & 0.318 & 1.782 & 0.047 & 1.809 & 5.954 & 0.150 & 6.207 & 4.48 & 5.30 \\
\hline $\mathrm{Tb}$ & 159 & 0.01 & 0.04 & 0.67 & 0.04 & 0.0007 & 1.87 & 0.09 & 0.002 & 0.059 & 0.002 & 0.060 & 0.342 & 0.010 & 0.362 & 0.883 & 0.021 & 0.939 & 0.72 & 0.86 \\
\hline Dy & 163 & 0.04 & 0.16 & 4.85 & 0.18 & 0.0048 & 14.41 & 1.04 & 0.016 & 0.418 & 0.019 & 0.420 & 2.464 & 0.084 & 2.544 & 5.053 & 0.158 & 5.280 & 4.42 & 5.06 \\
\hline Ho & 165 & 0.01 & 0.04 & 1.28 & 0.05 & 0.0013 & 3.46 & 0.22 & 0.004 & 0.094 & 0.004 & 0.095 & 0.549 & 0.018 & 0.572 & 0.938 & 0.027 & 0.989 & 0.89 & 1.04 \\
\hline $\mathrm{Er}$ & 167 & 0.04 & 0.13 & 4.96 & 0.25 & 0.0049 & 12.47 & 0.82 & 0.013 & 0.276 & 0.014 & 0.285 & 1.589 & 0.066 & 1.680 & 2.304 & 0.073 & 2.511 & 2.60 & 2.93 \\
\hline Tm & 169 & 0.00 & 0.03 & 1.07 & 0.04 & 0.0011 & 2.35 & 0.10 & 0.002 & 0.042 & 0.002 & 0.044 & 0.236 & 0.011 & 0.256 & 0.304 & 0.010 & 0.335 & 0.39 & 0.45 \\
\hline $\mathrm{Yb}$ & 173 & 0.01 & 0.04 & 10.13 & 0.87 & 0.0095 & 20.24 & 1.04 & 0.021 & 0.287 & 0.015 & 0.291 & 1.549 & 0.066 & 1.631 & 1.824 & 0.063 & 1.994 & 2.65 & 2.98 \\
\hline Lu & 175 & 0.01 & 0.05 & 2.25 & 0.12 & 0.0021 & 4.10 & 0.22 & 0.004 & 0.045 & 0.002 & 0.047 & 0.234 & 0.011 & 0.248 & 0.250 & 0.011 & 0.275 & 0.40 & 0.45 \\
\hline $\mathrm{Hf}$ & 178 & 0.05 & 0.29 & 3.46 & 1.05 & 0.0051 & 142.51 & 2.60 & 0.124 & 0.130 & 0.005 & 0.117 & 0.602 & 0.015 & 0.582 & 4.559 & 0.112 & 4.470 & 3.87 & 4.70 \\
\hline $\mathrm{Ta}$ & 181 & 0.14 & 0.12 & 0.70 & 0.13 & 0.0012 & 4.08 & 0.20 & 0.004 & 0.020 & 0.002 & 0.020 & 0.044 & 0.004 & 0.041 & 1.157 & 0.042 & 1.154 & 0.95 & 1.02 \\
\hline w & 182 & 0.86 & 2.10 & n.a. & & 0.0128 & 1117.4 & 79.24 & 0.855 & 21.08 & 0.50 & 19.66 & n.a. & & 0.027 & n.d. & & 0.251 & b.d.l. & \\
\hline $\mathrm{Pb}$ & 208 & 2.87 & 32.30 & 3652.0 & 124.5 & 3.8950 & 87.43 & 11.67 & 0.096 & 11.84 & 0.69 & 13.15 & 2.775 & 0.094 & 3.037 & 1.913 & 0.058 & 1.653 & 25.38 & 28.80 \\
\hline Th & 232 & 0.06 & 0.10 & 3.16 & 0.36 & 0.0029 & 12.26 & 0.71 & 0.013 & 0.060 & 0.005 & 0.071 & 0.028 & 0.001 & 0.033 & 1.119 & 0.015 & 1.224 & 9.94 & 11.30 \\
\hline U & 238 & 0.03 & 0.34 & 1.88 & 0.03 & 0.0017 & 11.70 & 0.55 & 0.013 & 0.047 & 0.003 & 0.059 & 0.009 & 0.0005 & 0.011 & 0.376 & 0.013 & 0.412 & 1.57 & 1.92 \\
\hline
\end{tabular}

Note : Mass : Mass used for ICP-MS analysis; DL : Detection Limit of the ICP-MS; Blank : Procedural Blank; $\sigma$ : standard deviation; Pref.Val.: Preferred values; $\mathrm{N}$ : average of N analyses; n.a. : not analyzed; n.d.: not determined 
Table S2: Summary statistics of the compiled composition of the Semail ophiolite mantle section peridotites subdivided by lithotypes $\mathrm{SiO} 2 \mathrm{TiO} 2 \mathrm{Al} 2 \mathrm{O} 3 \mathrm{FeOT} \mathrm{MnO} \mathrm{MgO} \mathrm{CaO} \mathrm{Na} 2 \mathrm{O} \mathrm{K} 2 \mathrm{O}$ P2O5 NiO Cr2O3 Total LOI Mg\# Fe ${ }^{3+} / \mathrm{Fe}_{-}$ wt.\% wt.\% wt.\% wt.\% wt.\% wt.\% wt.\% wt.\% wt.\% wt.\% wt.\% wt.\% wt.\%

$\begin{array}{lllllllllll}\mathrm{Li} & \mathrm{Sc} & \mathrm{Ti} & \mathrm{V} & \mathrm{Co} & \mathrm{Cr} & \mathrm{Ni} & \mathrm{Cu} & \mathrm{Zn} & \mathrm{Ga} & \mathrm{Rb}\end{array}$

$\mu \mathrm{g} / \mathrm{g} \mu \mathrm{g} / \mathrm{g} \quad \mu \mathrm{g} / \mathrm{g} \mu \mathrm{g} / \mathrm{g} \quad \mu \mathrm{g} / \mathrm{g} \quad \mu \mathrm{g} / \mathrm{g} \quad \mu \mathrm{g} / \mathrm{g} \mu \mathrm{g} / \mathrm{g} \quad \mu \mathrm{g} / \mathrm{g} \quad \mu \mathrm{g} / \mathrm{g} \mu \mathrm{g} / \mathrm{g}$

\begin{tabular}{|c|c|c|c|c|c|c|c|c|c|c|c|c|c|c|c|c|c|c|c|c|c|c|c|c|c|c|c|c|}
\hline \multirow{6}{*}{$\begin{array}{l}\text { Basal amphibole } \\
\text { bearing Iherzolite }\end{array}$} & $\mathrm{N}$ & 13 & 13 & 13 & 13 & 13 & 13 & 13 & 13 & 13 & 13 & 13 & 13 & 13 & 13 & 13 & & & 13 & 13 & 13 & 13 & 13 & 13 & 10 & 13 & & \\
\hline & Q16 & 45.43 & 0.02 & 1.89 & 6.66 & 0.11 & 40.83 & 1.61 & 0.02 & 0.00 & 0.00 & 0.00 & 0.00 & 100.00 & 8.00 & 90.58 & & & 11.8 & 144.4 & 58.1 & 97.7 & 2378 & 1740 & 14.3 & 40.0 & & \\
\hline & Median & 45.74 & 0.06 & 2.74 & 7.49 & 0.12 & 41.62 & 2.31 & 0.05 & 0.01 & 0.00 & 0.00 & 0.00 & 100.00 & 9.37 & 91.00 & & & 13.0 & 339.9 & 67.0 & 100.0 & 2470 & 1780 & 20.0 & 50.0 & & \\
\hline & $\mathrm{Q} 84$ & 46.40 & 0.07 & 2.92 & 7.76 & 0.15 & 42.67 & 2.89 & 0.08 & 0.02 & 0.00 & 0.00 & 0.00 & 100.00 & 10.97 & 91.91 & & & 14.0 & 427.2 & 73.2 & 103.2 & 2583 & 1935 & 30.0 & 151.8 & & \\
\hline & Mean & 45.79 & 0.05 & 2.43 & 7.33 & 0.13 & 42.03 & 2.18 & 0.05 & 0.01 & 0.00 & 0.00 & 0.00 & 100.00 & 9.57 & 91.10 & & & 12.5 & 302.6 & 64.2 & 100.1 & 2468 & 1822 & 21.0 & 85.4 & & \\
\hline & SD & 0.69 & 0.02 & 0.67 & 0.50 & 0.02 & 1.63 & 0.68 & 0.03 & 0.01 & 0.00 & 0.00 & 0.00 & 0.00 & 1.49 & 0.59 & & & 1.6 & 136.1 & 10.7 & 6.6 & 94 & 106 & 7.4 & 54.1 & & \\
\hline \multirow{6}{*}{ Basal herzolite } & $\mathrm{N}$ & 13 & 13 & 13 & 13 & 13 & 13 & 13 & 13 & 13 & 13 & 13 & 13 & 13 & 13 & 13 & & & 8 & 3 & 8 & 8 & 5 & 5 & & & 8 & 8 \\
\hline & Q16 & 44.58 & 0.00 & 1.40 & 7.92 & 0.13 & 41.01 & 1.22 & 0.00 & 0.00 & 0.00 & 0.32 & 0.28 & 99.99 & 3.80 & 89.99 & & & 11.6 & 42.1 & 52.6 & 101.0 & 2436 & 2273 & & & 0.72 & 0.07 \\
\hline & Median & 44.99 & 0.02 & 1.85 & 8.19 & 0.14 & 42.25 & 1.99 & 0.02 & 0.00 & 0.00 & 0.38 & 0.29 & 100.00 & 6.80 & 90.20 & & & 12.6 & 81.0 & 54.5 & 102.0 & 2558 & 2295 & & & 0.91 & 0.16 \\
\hline & Q84 & 45.47 & 0.06 & 2.48 & 8.28 & 0.14 & 42.86 & 2.61 & 0.10 & 0.01 & 0.00 & 0.39 & 0.40 & 100.20 & 8.09 & 90.50 & & & 14.8 & 216.7 & 65.9 & 103.9 & 2923 & 2405 & & & 1.06 & 0.19 \\
\hline & Mean & 45.07 & 0.03 & 1.96 & 8.11 & 0.14 & 42.00 & 2.00 & 0.04 & 0.00 & 0.00 & 0.37 & 0.34 & 100.05 & 6.24 & 90.22 & & & 13.1 & 128.3 & 57.7 & 102.3 & 2672 & 2328 & & & 0.92 & 0.14 \\
\hline & SD & 0.54 & 0.03 & 0.56 & 0.20 & 0.01 & 1.33 & 0.66 & 0.05 & 0.00 & 0.00 & 0.04 & 0.08 & 0.14 & 2.17 & 0.31 & & & 1.6 & 134.4 & 8.2 & 2.1 & 403 & 77 & & & 0.22 & 0.06 \\
\hline \multirow{6}{*}{ MMS } & $\mathrm{N}$ & 92 & 92 & 92 & 92 & 92 & 92 & 92 & 92 & 92 & 92 & 92 & 92 & 92 & 92 & 92 & 29 & 36 & 13 & 49 & 20 & 20 & 92 & 64 & 19 & 20 & 12 & 79 \\
\hline & Q16 & 42.55 & 0.00 & 0.46 & 7.95 & 0.11 & 44.62 & 0.50 & 0.00 & 0.00 & 0.00 & 0.00 & 0.00 & 99.08 & 6.71 & 90.40 & 0.28 & 0.47 & 4.8 & 24.0 & 18.8 & 105.7 & 2524 & 1955 & 6.7 & 35.1 & 1.88 & 0.02 \\
\hline & Median & 43.92 & 0.00 & 0.70 & 8.24 & 0.13 & 45.29 & 0.82 & 0.01 & 0.00 & 0.03 & 0.00 & 0.00 & 99.51 & 8.18 & 90.80 & 0.43 & 0.67 & 10.3 & 34.0 & 35.5 & 110.1 & 2911 & 2121 & 13.0 & 39.9 & 2.37 & 0.03 \\
\hline & Q84 & 44.56 & 0.02 & 1.03 & 8.73 & 0.14 & 46.80 & 1.07 & 0.05 & 0.02 & 0.07 & 0.29 & 0.39 & 100.00 & 10.62 & 91.10 & 0.51 & 0.94 & 10.8 & 55.0 & 42.3 & 122.8 & 3230 & 2334 & 27.6 & 43.9 & 3.77 & 0.05 \\
\hline & Mean & 43.49 & 0.01 & 0.74 & 8.32 & 0.13 & 45.69 & 0.81 & 0.05 & 0.02 & 0.03 & 0.07 & 0.09 & 99.45 & 8.50 & 90.73 & 0.42 & 0.79 & 8.8 & 39.9 & 32.8 & 113.1 & 2915 & 2144 & 18.9 & 39.9 & 2.53 & 0.03 \\
\hline & SD & 1.41 & 0.02 & 0.27 & 0.49 & 0.01 & 1.57 & 0.36 & 0.16 & 0.06 & 0.03 & 0.13 & 0.18 & 0.38 & 2.31 & 0.49 & 0.12 & 0.55 & 3.2 & 20.1 & 11.6 & 11.7 & 539 & 216 & 19.0 & 4.7 & 0.94 & 0.02 \\
\hline
\end{tabular}




\begin{tabular}{|c|c|c|c|c|c|c|c|c|c|c|c|c|c|c|c|c|c|c|c|c|c|c|c|c|c|c|c|c|c|}
\hline $\begin{array}{c}\mathrm{Sr} \\
\mu \mathrm{g} / \mathrm{g}\end{array}$ & Y & $\mathrm{Zr}$ & $\mathrm{Nb}$ & $\begin{array}{r}\text { Cs } \\
\mu \mathrm{g} / \mathrm{g} \\
\end{array}$ & $\begin{array}{r}\mathrm{Ba} \\
\mu \mathrm{g} / \mathrm{g} \\
\end{array}$ & $\begin{array}{r}\mathrm{La} \\
\mu \mathrm{g} / \mathrm{g} \\
\end{array}$ & $\begin{array}{c}\mathrm{Ce} \\
\mu \mathrm{g} / \mathrm{g} \\
\end{array}$ & $\begin{array}{r}\mathrm{Pr} \\
\mu \mathrm{g} / \mathrm{g} \\
\end{array}$ & $\begin{array}{r}\mathrm{Nd} \\
\mu \mathrm{g} / \mathrm{g} \\
\end{array}$ & $\begin{array}{l}\mathrm{Sm} \\
\mu \mathrm{g} / \mathrm{g} \\
\end{array}$ & $\begin{array}{r}\mathrm{Eu} \\
\mu \mathrm{g} / \mathrm{g} \\
\end{array}$ & $\begin{array}{r}\mathrm{Gd} \\
\mu \mathrm{g} / \mathrm{g} \\
\end{array}$ & $\begin{array}{r}\mathrm{Tb} \\
\mu \mathrm{g} / \mathrm{g} \\
\end{array}$ & $\begin{array}{c}\text { Dy } \\
\mu \mathrm{g} / \mathrm{g}\end{array}$ & $\begin{array}{r}\text { Ho } \\
\mu \mathrm{g} / \mathrm{g} \\
\end{array}$ & $\begin{array}{c}\mathrm{Er} \\
\mu \mathrm{g} / \mathrm{g} \\
\end{array}$ & $\begin{array}{c}\mathrm{Tm} \\
\mu \mathrm{g} / \mathrm{g} \\
\end{array}$ & $\begin{array}{r}\mathrm{Yb} \\
\mu \mathrm{g} / \mathrm{g} \\
\end{array}$ & $\begin{array}{r}\mathrm{Lu} \\
\mu \mathrm{g} / \mathrm{g} \\
\end{array}$ & $\begin{array}{r}\mathrm{Hf} \\
\mu \mathrm{g} / \mathrm{g} \\
\end{array}$ & $\begin{array}{c}\mathrm{Ta} \\
\mu \mathrm{g} / \mathrm{g} \\
\end{array}$ & $\begin{array}{r}\mathrm{Pb} \\
\mu \mathrm{g} / \mathrm{g} \\
\end{array}$ & $\begin{array}{c}\text { Th } \\
\mu \mathrm{g} / \mathrm{g} \\
\end{array}$ & $\begin{array}{r}U \\
\mu \mathrm{g} / \mathrm{g} \\
\end{array}$ & $\begin{array}{c}\Sigma \mathrm{HFSE} \\
\mu \mathrm{g} / \mathrm{g}\end{array}$ & $\mu \mathrm{g} / \mathrm{g}$ & $\begin{array}{l}\text { 2REE+Y } \\
\mu \mathrm{g} / \mathrm{g}\end{array}$ & $\mu \mathrm{g} / \mathrm{g}$ & $\begin{array}{l}\mathrm{Nb} / \mathrm{Zr} \\
\mu \mathrm{g} / \mathrm{g}\end{array}$ \\
\hline 12 & 11 & 2 & & 13 & 7 & 8 & 12 & 10 & 8 & 12 & 8 & 11 & 11 & 13 & 12 & 13 & 13 & 13 & 13 & & & & & & 13 & 13 & 13 & 12 & \\
\hline 6.50 & 1.42 & 1.16 & & 0.682 & 4.000 & 0.060 & 0.087 & 0.010 & 0.092 & 0.020 & 0.021 & 0.100 & 0.020 & 0.114 & 0.037 & 0.104 & 0.016 & 0.114 & 0.026 & & & & & & 0.00 & 0.55 & 1.17 & 0.37 & \\
\hline 10.50 & 1.60 & 1.50 & & 1.100 & 4.000 & 0.070 & 0.105 & 0.020 & 0.110 & 0.075 & 0.036 & 0.150 & 0.040 & 0.260 & 0.060 & 0.190 & 0.029 & 0.210 & 0.036 & & & & & & 0.00 & 1.26 & 2.86 & 0.45 & \\
\hline 21.25 & 2.10 & 1.84 & & 2.764 & 8.230 & 0.235 & 0.265 & 0.026 & 0.213 & 0.115 & 0.042 & 0.186 & 0.044 & 0.342 & 0.073 & 0.240 & 0.040 & 0.292 & 0.050 & & & & & & 0.09 & 1.94 & 3.88 & 2.00 & \\
\hline 13.33 & 1.68 & 1.50 & & 1.562 & 5.857 & 0.125 & 0.178 & 0.025 & 0.173 & 0.073 & 0.032 & 0.139 & 0.035 & 0.238 & 0.055 & 0.176 & 0.029 & 0.205 & 0.036 & & & & & & 0.23 & 1.34 & 2.76 & 1.15 & \\
\hline 9.00 & 0.44 & 0.71 & & 1.097 & 3.485 & 0.103 & 0.163 & 0.024 & 0.140 & 0.041 & 0.011 & 0.058 & 0.014 & 0.109 & 0.021 & 0.074 & 0.013 & 0.086 & 0.013 & & & & & & 0.60 & 0.73 & 1.41 & 1.28 & \\
\hline 8 & 8 & 8 & 8 & 8 & 8 & 5 & 7 & 6 & 8 & 8 & 8 & 8 & 8 & 8 & 8 & 8 & & 8 & 8 & 8 & 8 & 8 & 8 & 8 & 13 & 13 & 13 & 7 & 8 \\
\hline 1.62 & 0.61 & 0.02 & 0.015 & 0.094 & 0.102 & 0.002 & 0.001 & 0.002 & 0.003 & 0.005 & 0.003 & 0.023 & 0.008 & 0.068 & 0.021 & 0.073 & & 0.105 & 0.018 & 0.002 & 0.003 & 0.004 & 0.0009 & 0.0001 & 0.00 & 0.00 & 0.00 & 0.01 & 0.02 \\
\hline 6.08 & 1.35 & 0.12 & 0.015 & 0.183 & 0.357 & 0.002 & 0.027 & 0.009 & 0.034 & 0.037 & 0.018 & 0.097 & 0.024 & 0.183 & 0.046 & 0.145 & & 0.165 & 0.027 & 0.016 & 0.003 & 0.005 & 0.0011 & 0.0002 & 0.06 & 0.31 & 0.90 & 0.14 & 0.15 \\
\hline 22.95 & 1.75 & 0.86 & 0.016 & 0.519 & 1.044 & 0.015 & 0.050 & 0.017 & 0.131 & 0.081 & 0.036 & 0.151 & 0.033 & 0.237 & 0.058 & 0.184 & & 0.208 & 0.033 & 0.046 & 0.008 & 0.019 & 0.0015 & 0.0002 & 0.77 & 1.12 & 2.80 & 0.22 & 0.76 \\
\hline 12.87 & 1.30 & 0.38 & 0.016 & 0.283 & 0.496 & 0.008 & 0.024 & 0.010 & 0.063 & 0.046 & 0.021 & 0.099 & 0.023 & 0.174 & 0.044 & 0.140 & & 0.161 & 0.027 & 0.023 & 0.007 & 0.010 & 0.0012 & 0.0002 & 0.26 & 0.51 & 1.31 & 0.13 & 0.31 \\
\hline 15.19 & 0.67 & 0.45 & 0.001 & 0.259 & 0.467 & 0.012 & 0.023 & 0.008 & 0.070 & 0.043 & 0.018 & 0.074 & 0.015 & 0.100 & 0.022 & 0.064 & & 0.058 & 0.008 & 0.023 & 0.010 & 0.009 & 0.0004 & 0.0001 & 0.42 & 0.56 & 1.39 & 0.13 & 0.36 \\
\hline 81 & 59 & 75 & 81 & 74 & 69 & 54 & 69 & 38 & 63 & 33 & 56 & 74 & 75 & 83 & 81 & 83 & 81 & 83 & 77 & 58 & 54 & 34 & 56 & 40 & 92 & 92 & 92 & 69 & 75 \\
\hline 0.46 & 0.05 & 0.01 & 0.015 & 0.002 & 0.070 & 0.002 & 0.002 & 0.001 & 0.004 & 0.002 & 0.001 & 0.003 & 0.001 & 0.007 & 0.002 & 0.011 & 0.002 & 0.022 & 0.005 & 0.001 & 0.001 & 0.015 & 0.0007 & 0.0005 & 0.03 & 0.05 & 0.07 & 0.08 & 0.27 \\
\hline 2.32 & 0.10 & 0.03 & 0.022 & 0.004 & 0.152 & 0.003 & 0.004 & 0.001 & 0.006 & 0.005 & 0.002 & 0.006 & 0.001 & 0.012 & 0.004 & 0.017 & 0.004 & 0.031 & 0.007 & 0.003 & 0.001 & 0.020 & 0.0010 & 0.0010 & 0.05 & 0.09 & 0.14 & 0.17 & 0.70 \\
\hline 7.62 & 0.19 & 0.08 & 0.029 & 0.012 & 0.295 & 0.006 & 0.012 & 0.002 & 0.015 & 0.011 & 0.003 & 0.012 & 0.003 & 0.028 & 0.008 & 0.029 & 0.006 & 0.045 & 0.009 & 0.005 & 0.002 & 0.054 & 0.0019 & 0.0013 & 0.11 & 0.16 & 0.28 & 0.41 & 1.82 \\
\hline 4.36 & 0.11 & 0.04 & 0.023 & 0.009 & 0.189 & 0.004 & 0.008 & 0.002 & 0.009 & 0.006 & 0.002 & 0.008 & 0.002 & 0.015 & 0.005 & 0.019 & 0.004 & 0.033 & 0.007 & 0.003 & 0.001 & 0.030 & 0.0012 & 0.0010 & 0.06 & 0.10 & 0.17 & 0.25 & 1.00 \\
\hline 5.51 & 0.06 & 0.04 & 0.009 & 0.014 & 0.148 & 0.004 & 0.009 & 0.001 & 0.007 & 0.005 & 0.002 & 0.005 & 0.001 & 0.010 & 0.003 & 0.009 & 0.002 & 0.012 & 0.002 & 0.002 & 0.001 & 0.020 & 0.0006 & 0.0006 & 0.05 & 0.06 & 0.12 & 0.27 & 0.94 \\
\hline
\end{tabular}


Table S3: Summary statistics of Semail mantle peridotites and BT1B lithologies, recalculated to include volatile components, used in mass balance calculations

Massif Stat $\mathrm{SiO2}^{*} \mathrm{Al}_{203^{*}} \mathrm{FeOT}^{*} \mathrm{MgO}^{*} \mathrm{CaO}^{*} \mathrm{~K}_{2} \mathrm{O}^{*} \mathrm{H}_{2} \mathrm{O}^{+} \mathrm{CO}+\mathrm{C}$

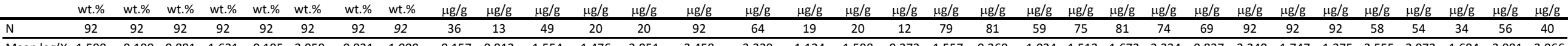

$\mathrm{Cu} \quad \mathrm{Zn} \quad \mathrm{Ga} \quad \mathrm{Rb}$

$\mathrm{Zr} \quad \mathrm{Nb}$

Ba ELREE EMREE EHREE Hf

$\mathrm{Pb} \quad \mathrm{Th} \quad \mathrm{H}$

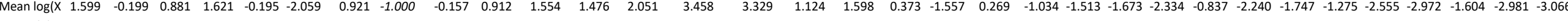

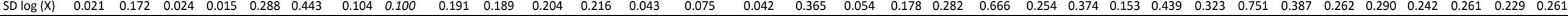

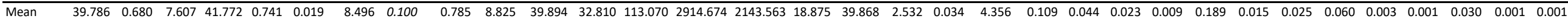

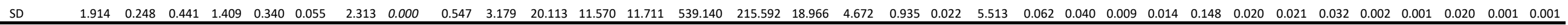

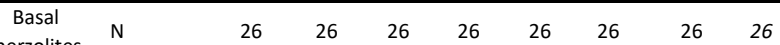

\begin{tabular}{lllllllll}
\hline Mean $\log (\mathrm{X}$ & 1.621 & 0.282 & 0.851 & 1.587 & 0.261 & -2.705 & 0.869 & -1.000
\end{tabular} $\begin{array}{llllllllll}\mathrm{SD} \log (\mathrm{X}) & 0.011 & 0.148 & 0.040 & 0.016 & 0.152 & 0.673 & 0.176 & 0.100\end{array}$ \begin{tabular}{lllllllll}
\hline Mean & 41.834 & 2.016 & 7.120 & 38.685 & 1.929 & 0.006 & 7.905 & 0.100
\end{tabular}

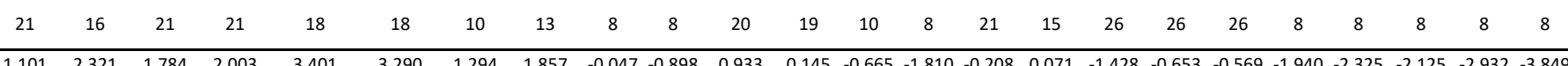
\begin{tabular}{llllllllllllllllllllllll}
0.056 & 0.372 & 0.075 & 0.023 & 0.036 & 0.053 & 0.170 & 0.252 & 0.098 & 0.224 & 0.485 & 0.196 & 0.763 & 0.020 & 0.509 & 0.703 & 1.159 & 0.483 & 0.408 & 0.613 & 0.354 & 0.360 & 0.119 & 0.155 \\
\hline 12.705 & 269.913 & 61.681 & 100.919 & 2524.500 & 1962.222 & 21.000 & 85.385 & 0.919 & 0.141 & 13.147 & 1.521 & 0.602 & 0.016 & 1.074 & 2.998 & 0.213 & 0.347 & 0.363 & 0.023 & 0.007 & 0.010 & 0.001 & 0.000
\end{tabular} $\begin{array}{llllllllll}\text { SD } & 1.075 & 0.592 & 0.623 & 1.491 & 0.616 & 0.009 & 2.466 & 0.000\end{array}$ \begin{tabular}{lllllllllllllllllllllllll}
12.705 & 269.913 & 61.681 & 100.919 & 2524.500 & 1962.222 & 21.000 & 85.385 & 0.919 & 0.141 & 13.147 & 1.521 & 0.602 & 0.016 & 1.074 & 2.998 & 0.213 & 0.347 & 0.363 & 0.023 & 0.007 & 0.010 & 0.001 & 0.000 \\
1.566 & 146.474 & 9.983 & 5.304 & 227.690 & 249.078 & 7.182 & 53.008 & 0.208 & 0.057 & 11.339 & 0.556 & 0.646 & 0.001 & 1.060 & 3.540 & 0.312 & 0.282 & 0.249 & 0.022 & 0.009 & 0.009 & 0.000 & 0.000 \\
\hline
\end{tabular}

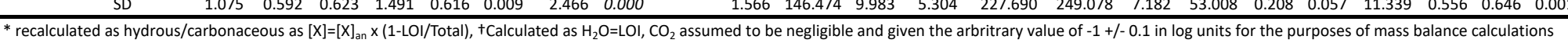

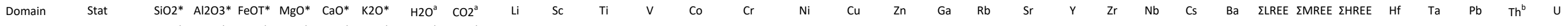

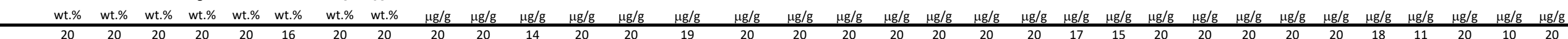

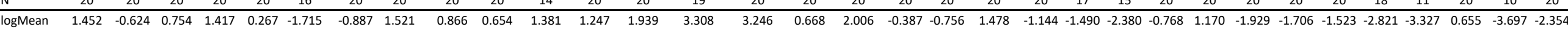

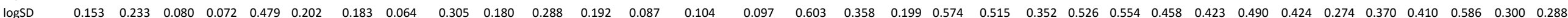

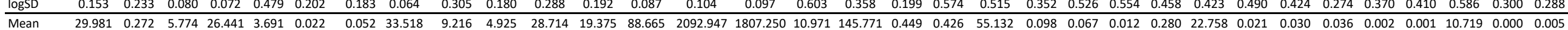

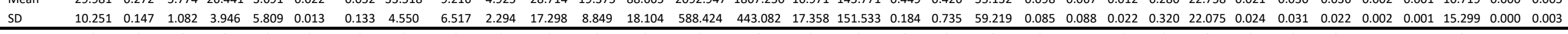

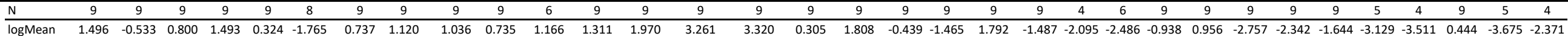

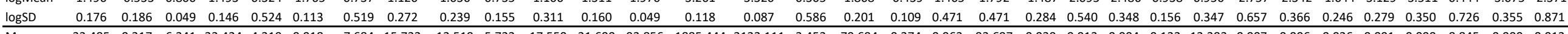

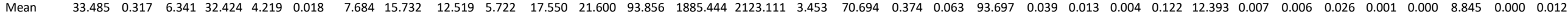

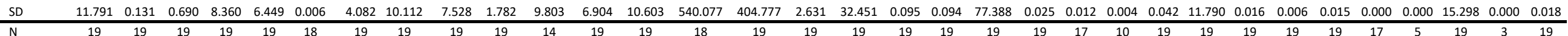

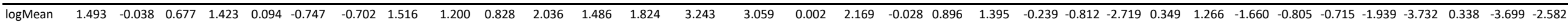

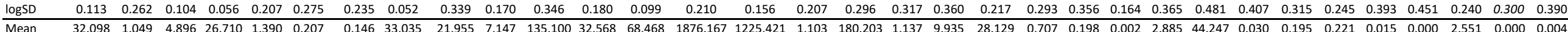

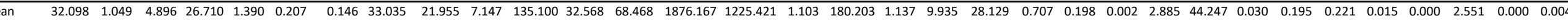

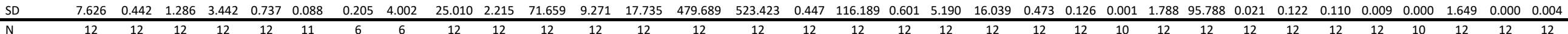

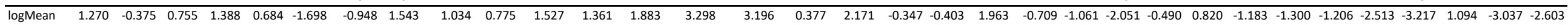

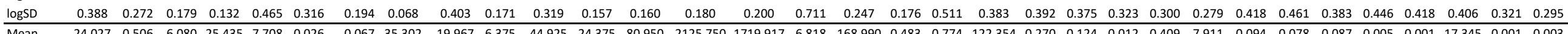

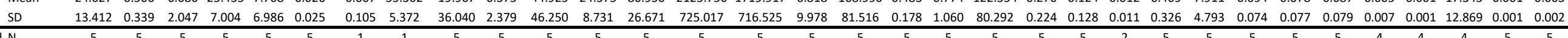

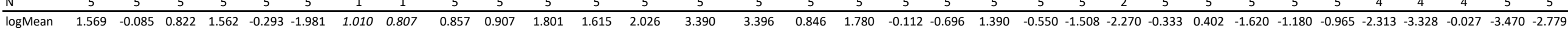

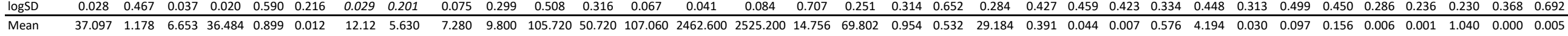
SD $\quad \begin{array}{lllllll}2.415 & 0.842 & 0.573 & 1.671 & 0.974 & 0.008\end{array}$

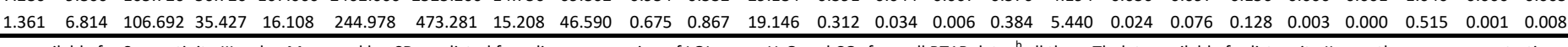

(1) 
Caption for Dataset S1. Mineralogy, major, volatile and trace element composition of OmanDP Hole BT1B samples (Semail ophiolite)

The rock names and grouping by Units were determined on-board D/V Chikyu from macroscopic observations (Visual Core Description; Kelemen et al. [2020]). Major and trace element concentrations were measured by X-ray fluorescence (XRF). XRF analyses of shipboard and on-site samples noted * in the Method columns were realized on-board D/V Chikyu (Note that major oxide concentrations in Kelemen et al. [2020] are recalculated to 100 wt.\%) and those noted † in the Method columns were realized at the University of St. Andrews (see Table BT1-T12 in Kelemen et al. [2020]). XRF analyses of consortium samples were realized at Geolabs. FeO concentrations were measured by titration at the University of Lausanne (Switzerland). Total $\mathrm{H}$ and $\mathrm{C}$ concentrations (noted TH and TC) were determined on-board D/V Chikyu by combustion CHNS elemental analysis (EA) and used to recalculate $\mathrm{H}_{2} \mathrm{O}$ and $\mathrm{CO}_{2}$ contents. Concentrations of carbon in Ca-carbonates (total inorganic carbon; noted TIC) were determined by coulometry. Trace element compositions were determined using a Quadrupole Inductively-Coupled-Plasma-Mass Spectrometer (Q-ICP-MS) at the University of Montpellier (France). All analyses were performed on samples prepared from non-ignited rock-powders, except for XRF major element analyses realized on beads on-board D/V Chikyu. Concentrations are reported in wt. $\%\left(10^{-2} \mathrm{~g} / \mathrm{g}\right)$ and in ppm $\left(10^{-6} \mathrm{~g} / \mathrm{g}\right)$.

Abbreviations: mbg: meters below ground (Chikyu curated depth); Fu-listvenite : fuchsitebearing listvenite; LOI : Loss on ignition; XRF B : XRF analyses on beads; XRF P : XRF analyses on powder pellets; XRF B/P : XRF major element analyses on beads except for $\mathrm{K}$ measured on pellets and recalculated as volatile free; n.a.: not analysed; n.d.: not determined.

(Notes, abbreviations \& reference at the bottom of the file)

\# Sample C5704B-60Z-4-1, 24.0--29.0 cm: Green matrix (Host: Sample C5704B-60Z-4-1, 24.0-$29.0 \mathrm{~cm}-\mathrm{H}$ ) crosscut by pink vein (Vein : Sample C5704B-60Z-4-1, 24.0--29.0 cm - V)

Reference : Kelemen, P. B., J. M. Matter, D. A. H. Teagle, J. A. Coggon, and the Oman Drilling Project Science Team (2020), Proceedings of the Oman Drilling Project, College Station, TX.

The dataset is available on the PANGAEA data archiving platform (https://doi.pangaea.de/10.1594/PANGAEA.937490). 